LUCAS MIRANDA MARQUES

\title{
ESTUDO DA VARIABILIDADE GENÉTICA E DOS FATORES \\ DE VIRULÊNCIA DE ISOLADOS DE Ureaplasma diversum
}

Tese de Doutorado apresentada ao Instituto de Ciências Biomédicas da Universidade de São Paulo, para obtenção do Título de Doutor em Ciências (Microbiologia). 
LUCAS MIRANDA MARQUES

\section{ESTUDO DA VARIABILIDADE GENÉTICA E DOS FATORES \\ DE VIRULÊNCIA DE ISOLADOS DE Ureaplasma diversum}

Tese de Doutorado apresentada ao Instituto de Ciências Biomédicas da Universidade de São Paulo, para obtenção do Título de Doutor em

Ciências (Microbiologia).

Área de Concentração:

Microbiologia

Orientador:

Prof. Dr. Jorge Timenetsky

Co-Orientador:

Profa. Dra. Melissa Buzinhani 
DADOS DE CATALOGAÇÃO NA PUBLICAÇÃO (CIP)

Serviço de Biblioteca e Informação Biomédica do

Instituto de Ciências Biomédicas da Universidade de São Paulo

(c) reprodução total

Marques, Lucas Miranda.

Estudo da variabilidade genética e dos fatores de virulência de isolados de Ureaplasma diversum / Lucas Miranda Marques. -- São Paulo, 2009.

Orientador: Jorge Timenetsky.

Tese (Doutorado) - Universidade de São Paulo. Instituto de Ciências Biomédicas. Departamento de Microbiologia. Área de concentração: Microbiologia. Linha de pesquisa: Micoplasmose animal.

Versão do título para o inglês: Study of genetic variability and virulence factors of Ureaplasma diversum isolates.

Descritores: 1. Ureaplasma diversum 2. Variablidade genética 3. Cápsula 4. Fosfolipase C 5. IgA protease 6. Invasão bacteriana I. Timenetsky, Jorge II. Universidade de São Paulo. Instituto de Ciências Biomédicas. Programa de Pós-Graduação em Microbiologia. III. Título. 


\section{UNIVERSIDADE DE SÃO PAULO \\ INSTITUTO DE CIÊNCIAS BIOMÉDICAS}

Candidato(a): $\quad$ Lucas Miranda Marques.

Título da Tese: $\quad$ Estudo da variabilidade genética e dos fatores de virulência de isolados de Ureaplasma diversum .

Orientador(a): Jorge Timenetsky.

A Comissão Julgadora dos trabalhos de Defesa da Tese de Doutorado, em sessão pública realizada a , considerou

\section{( ) Aprovado(a) ( ) Reprovado(a)}

Examinador(a): Assinatura:

Nome:

Instituição:

Examinador(a): Assinatura:

Nome:

Instituição:

Examinador(a): Assinatura:

Nome:

Instituição:

Examinador(a): Assinatura:

Nome:

Instituição:

Presidente: Assinatura:

Nome:

Instituição: 


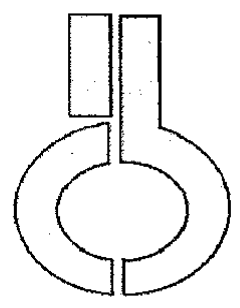

\section{UNIVERSIDADE DE SAO PAULO INSTITUTO DE CIÊNCIAS BIOMÉDICAS}

Cidade Universitária "Armando de Salles Oliveira"

Av. Prof. Lineu Prestes, 2415 - CEP. 05508-000 Säo Paulo, SP - Brasil

Telefone :(55) (011) 3091.7733 - telefax : (55) (011) 3091.7438

e-mail:

\section{Certificado}

Certificamos que o protocolo registrado sob $n^{\circ} 052$ nas fls. 32 do livro 2 para uso de animais em experimentação, sob a responsabilidade de Jorge Timenetsky, Coordenador(a) da Linha de Pesquisa "Estudo da variabilidade genética dos genes da uréase e do superantigeno mba e dos fatores de virulência de amostras de campo de Ureaplasma" do qual participou(aram) o(s) alunos Lucas Miranda Marques, está de acordo com os Principios Éticos de Experimentação Animal adotado pelo Colégio Brasileiro de Experimentação Animal (COBEA) e foi aprovado pela COMISSÃO DE ÉTICA EM EXPERIMENTAÇÃO ANIMAL (CEEA) em 20.04.2006.

São Paulo, 24 de abril de 2006.

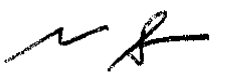

Profa. Dra. Marília C.L.Seelaender Coordenadora -CEEA - ICB/USP

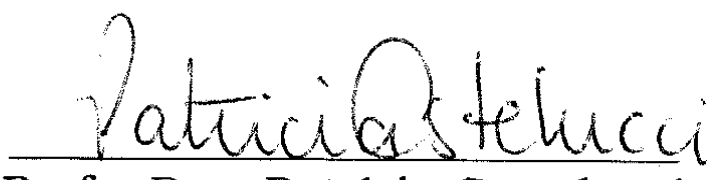

Profa. Dra. Patricia Castelucci Secretária Suplente CEEA - ICB/USP 
Aos meus pais, Ivan e Nilda, dedico todo esse trabalho e agradeço por tudo e por minha formação, pois hoje sou quem sou graças a educação que me deram. 


\section{AGRADECIMENTO ESPECIAL}

A Fundação de Amparo à Pesquisa do Estado de São Paulo

(FAPESP) pelo apoio financeiro, sem o qual este estudo não seria realizado. 


\section{AGRADECIMENTOS}

A Deus, minha luz e meu caminho...

Aos meus pais, Ivan e Nilda, meus irmãos, Thiago e Daniel, minha cunhada Tânia e meus sobrinhos, Gu e Pepê, que são à base da minha vida. Obrigado por tudo, pois deve a vocês tudo o que sou e serei.

Ao meu orientador, Dr. Jorge Timenetsky, pela confiança e oportunidade no desenvolvimento deste trabalho. Uma pessoa realmente admirável. Espero continuar trabalhando com ele por um bom tempo!!

A minha co-orientadora, Dra Melissa Buzinhani, sempre pronta para me ajudar! Também espero continuar trabalhando com ela por um bom tempo!!

Á Celma pela contribuição na execução do trabalho e pela valiosa amizade conquistada. Muito Obrigado. Você foi essencial principalmente nos momentos mais dificeis deste trabalho!

A Elena, pela ajuda e confiança no início da minha vida como micoplasmologista.

Aos amigos do laboratório, Juliana, Carol, Liliane, Marcos, Maurício, Melissa, Nany, Priscila, Ana Marcia, Denise e Renata, pela ajuda e companheirismo durante o desenvolvimento deste trabalho. Mais do que companheiros de trabalho, vocês são meus companheiros de vida.

Aos Prof. Dr. Victor Elias Arana-Chaves e Profa. Dra. Glaucia Maria Machado-Santelli, do Departamento de de Biologia Celular e do 
Desenvolvimento, por abrirem as portas de seus laboratórios e pelo valioso auxilio com as técnicas de microscopia.

Aos técnicos Fernanda, Edson, Gaspar e Roberto pela grande ajuda com as ténicas de microscopia eletrônica e confocal.

As pós-graduandas Regina, pela ajuda com o sequenciamento realizado neste trabalho, e Beatriz, pela ajuda com as técnicas de microscopia confocal. Pessoas especiais que ficarão em meu coração.

Aos funcionários da sala de esterilização do ICB II, pela enorme prestatividade.

As funcionárias, Alice, Aninha e Naíde, da secretaria do departamento de microbiologia do ICB II. Muito Obrigada.

Aos funcionários da biblioteca do Instituto de Ciências Biomédicas pelo auxílio prestado na preparação deste trabalho.

A Universidade Federal da Bahia, especialmente, o campus Anísio Teixeira, pela liberação para a realização da parte experimental de meu trabalho.

Aos meus grandes amigos de sempre, Lídia, Rose, Renata, Thiago, Magda e Erly, que continuam meus companheiros de jornada e da qual não seria nada sem eles. Obrigado por tudo.

Aos amigos conquistados durante a realização desta dissertação: Alexandre, Arianne, Ana Cláudia, Amanda, Alessandra, Cássia, Elessandra, Jacinta, Luis Fernando, Patrícia, Rubens, Sheila, Viviane e Zigue. Que essa amizade siga para sempre. 
Aos amigos "conquistenses" conquistados na nova etapa de minha vida (Vitória da Conquista): Adriano, Amélia, Anderson, Angélica, Braga Junior, Cristiano, Dica, Djanilson, Fabiane, Francine, Gil, Gisele, Handyara, Igor, Patricio, Laize, Luciano, Maise, Mariluze, Marco, Najara, Raquel, Regiane, Robson, Sávio, Telma e Tiana. Sem vocês Conquista não teria a menor graça... nossa vida kinder ovo!! Que essa amizade também siga para sempre.

Aos meus companheiros de casa: Gil, Maise, Robson e agora, Braga, pela grande ajuda nestes dois anos de Vitória da Conquista. Foram grandes horas de conversas, com alegrias e poucas tristezas.

Á todos meus outros amigos aqui não mencionados, que ás vezes com poucas palavras puderam me incentivar a percorrer e concluir esta etapa.

A todos, aqui não mencionados, que de alguma forma viabilizaram o desenvolvimento deste trabalho. 
“A única certeza estável é a certeza de que tudo vai mudar...."

Luiz Marins 


\section{RESUMO}

MARQUES, L.M. Estudo da variabilidade genética e dos fatores de virulência de isolados de U. diversum. $100 \mathrm{f}$. Tese (Doutorado) - Instituto de Ciências Biomédicas da Universidade de São Paulo, São Paulo, 2009.

A patogenicidade e as características genéticas de $U$. diversum são pouco conhecidas. Estudou-se a variabilidade genética e dos fatores de virulência de de $U$. diversum obtidos de bovinos. Foram comparadas duas cepas ATCC e 34 isolados de campo, sendo 24 isolados de fêmeas com distúrbios reprodutivos e 10 isolados de sêmen bovino. As cepas foram submetidas a identificação pela PCR tendo como alvo os fragmentos do gene 16S rRNA e urease. Os produtos foram analisados quanto a variabilidade genética. A cápsula, atividade da fosfolipase C e IgAse, adesão e invasão em células Hep-2 foram avaliadas nos isolados e cepas de referência. $O$ sequênciamento parcial do gene 16S rRNA evidenciou polimorfismos em 44 posições e os microrganismos foram divididos em sete "clusters". A amostras de ureaplasma estudadas possuíam uma camada densa ao redor da membrana celular dos microrganismos, sendo esta, a primeira descrição de material do tipo capsular nestes microrganismos. Entre as amostras de $U$. diversum, 31 apresentaram alta atividade de fosfolipase $\mathrm{C}$, mas nenhuma apresentou atividade de IgA protease. A aderência e invasão em células Hep-2 foi observada em microscopia confocal e conformada pelo teste da gentamicina. Todos os ureaplasma foram detectados no interior das células após um minuto de infecção. Após 3 horas de infecção, estes microrganismos mostraram-se mais concentrados na região perinuclear das células, mas não no interior do núcleo. No teste da gentamicina, verificou-se que $1 \%$ do inoculo inicial dos microrganismos das cepas ATCC estavam no interior das células e $10 \%$ foi detectado dos isolados clínicos. O número de passagens in vitro das amostras de campo não influenciou os resultados. As amostras de $U$. diversum deste estudo evidenciaram propriedades biológicas não conhecidas e estas características contribuem na compreensão das infecções nos animais e bem como a sua diversidade genética.

Palavras-chave: Ureaplasma diversum, variabilidade genética, cápsula, fosfolipase $\mathrm{C}$, IgA protease, invasão bacteriana. 


\begin{abstract}
MARQUES, L.M. Study of genetic variability and virulence factors of $U$. diversum isolates. $100 \mathrm{f}$. Tese (Doutorado) - Instituto de Ciências Biomédicas da Universidade de São Paulo, São Paulo, 2009.
\end{abstract}

Little is known about the pathogenicity and genetic characteristic of $U$. diversum. The aim of the present study was the study of genetic variability and virulence factors of $U$. diversum clinical isolates. Thirty four isolates of $U$. diversum and two type-strains, ATCC 49782 and 49783, were studied. Twenty four isolates were recovered from the vaginal mucus of a bovine vulvovaginitis and 10 isolates were recovered from frozen bovine semen. The strains were submitted to PCR assays for 16S rRNA and urease genes, and analyzed to genetic variability. Moreover, the strains were analyzed to the virulence factors: capsule, phospholipase $C$ activity, IgA protease activity and adheson and invasion into Hep-2 cells. The sequencing of parcial 16S rRNA gene showed polymorphic patterns into 44 positions. This polymorphisms clustered the strins in seven groups. For the virulence factors, ureaplasma cells showed a dense-stained external capsule-like structure surrounding the cell membrane. This is the first description in U. diversum. A high level of phospholipase C activity was also detected in 31 studied ureaplasma. However, no strains showed IgA protease activity. For the invasion assay, the isolates and strains used were detected inside the cells after infection of one minute without difference in the arrangement for adhesion and invasion. The adhesion was scattered throughout the cells, and after three hours, the invasion, of the ureaplasmas surrounded the nuclear region but were not observed inside the nuclei. The gentamicin invasion assay detected that $1 \%$ of the ATCC strains were inside the infected Hep-2 cells in contrast to $10 \%$ to the clinical isolates. The results presented herein will help better understand $U$. diversum infections and genetic diversity, as much as cellular attachment and virulence.

Keywords: Ureaplasma diversum, genetic variability, capsule, phospholipase $\mathrm{C}, \lg \mathrm{A}$ protease, bacterial invasion. 


\section{LISTA DE FIGURAS}

Figura 1. Morfologia dos micoplasmas. Foto cedida pelo Prof. Dr. Michael Rabinovich

Figura 2. Crescimento em meio sólido como colônias em forma de "ovo frito". Aumento de $100 \mathrm{X}$

Figura 3. Eletroforese em gel de agarose dos produtos da PCR utilizando "primers" F16S e R16S a partir do DNA de U. diversum. Linhas 1 a 10: isolados de U. diversum. Linha 11: padrão de peso molecular $-1 \mathrm{Kpb}$

Figura 4. Analise de similaridade da seqüência parcial do gene 16S de amostras de U. diversum e seqüência 16S rRNA depositada no GenBank, realizada pelo método Clustal-W do programa MEGA - 4 .

Figura 5. Dendograma obtidos do sequenciamento parcial do gene 16S rRNA (5'$\left.3^{\prime}\right)$ de isolados de $U$. diversum isolados de bovinos. O método de construção foi calculado pelo algoritmo "Neighbor-Joining" com "Bootstrap" de 1.000 repetições.

Figura 6. Eletroforese em gel de agarose dos produtos amplificados na PCR utilizando "primers" 14b e 72c com DNA dos isolados e das cepas de referência de $U$. diversum. Colunas 1 a 15: amostras amplificadas; Coluna 16: amostra não amplificada; Coluna 17: controle negativo; Coluna 18: peso molecular $100 \mathrm{pb}$.

Figura 7. Microscopia eletrônica obtida de cepas de U. diversum tratadas com vermelho de ruteno, evidenciando material polissacarídico. A) isolado 77 (vaca); B) isolado 10T (touro). Barra 100nm ....

Figura 8. Figura evidenciando a alta atividade de fosfolipase de algumas cepas de $U$. diversum testadas. A) Amostras fosfolipase positiva; B) Controle negativo

Figura 9. Atividade de fosfolipase $\mathrm{C}$ avaliada nas cepas de $U$. diversum estudadas. A absorbância foi determinada em $405 \mathrm{~nm}$ após 24 horas de incubação a $37^{\circ} \mathrm{C}$ em caldo UB com pNPPC

Figura 10. Atividade de fosfolipase $C$ avaliada nas cepas de $U$. diversum estudadas no teste de adesão e invasão. A absorbância foi determinada em $405 \mathrm{~nm}$ após 24 horas de incubação a $37^{\circ} \mathrm{C}$ em caldo UB com pNPPC

Figura 11. Perfis protéicos (A) e representação esquemática (B) de lgA bovina após exposição por $24 \mathrm{~h}$ com cepa 49782 de U. diversum. Colunas 1: Padrão de peso molecular; Colunas 2: perfil protéico obtido do $U$. diversum 49782; Colunas 3: perfis protéicos obtido após $24 \mathrm{~h}$ de incubação do $U$. diversum 49782 incubado com a slgA bovina; Colunas 4: slgA bovina.....

Figura 12. Microscopia confocal evidenciando a internalização de U. diversum em células HEp-2 cells após 1 minuto (1), 30 minutos (2), 3 horas (3) e 12 horas (4) de infecção. Ureaplasmas foram marcados com Vibrant Dil (vermelho, A), filamentos de actina de HEp-2 foram marcados com FITC (verde, B) e o núcleo das células Hep-2 marcado com TO-PRO-3 (azul, C). Em D, sobreposição das imagens A, B, e C 
Figura 13. Microscopia confocal evidenciando a internalização de U. diversum em células HEp-2. Ureaplasmas foram marcados com Vibrant Dil (vermelho), filamentos de actina de HEp-2 foram marcados com FITC (verde) e o núcleo das células Hep-2 marcado com TO-PRO-3 (azul). A e B: secções ópticas $(A)$ e projeções ortogonais $(B)$ evidenciando a presença e distribuição dos ureaplasmas no interior de células Hep-2. C: Imagem e representação gráfica obtidas da localização dos ureaplasmas no interior de células Hep-2 após 12 horas de infecção, evidenciando os picos em vermelho (ureaplasmas) em um região perinuclear

Figura 14. Células HEp-2 infectadas que foram submetidas a imunoflorescência com anticorpo anti-lamina (verde), evidenciando os ureaplasmas (vermelho) em um região perinuclear, mas não no interior do núcleo 


\section{LISTA DE QUADROS}

Quadro 1 - "Primers" para a detecção do gene 16S rRNA ...................... 44

Quadro 2 - "Primers" para a detecção do gene da urease ...................... 45 


\section{LISTA DE TABELAS}

Tabela 1 - Polimorfismos entre as seqüências parciais do gene 16S rRNA de cepas e isolados de $U$. diversum e sequencia depositada no GenBank

Tabela 2 - Freqüência de invasão das cepas de U. diversum inoculadas em células Hep-2 


\section{SUMÁRIO}

1 INTRODUÇÃO 18

2 REVISÃO DE LITERATURA 20

2.1 Características gerais dos molicutes $\quad 20$

2.2 Micoplasmas animais $\quad 30$

2.3 Ureaplasma diversum 33

3 OBJETIVOS 40

3.1 Objetivos Gerais 40

3.2 Objetivos específicos $\quad 40$

4 MATERIAL E MÉTODOS 41

4.1 Cepas de ureaplasmas $\quad 41$

4.2 Meio de Cultura 41

4.2.1 Meio Ureaplasma Líquido $(100 \mathrm{~mL})$

4.2.2 Meio Ureaplasma Sólido $(100 \mathrm{~mL})$

4.3 Subcultivo das cepas e estirpes de U. diversum 42

4.4 Sequênciamento dos nucleotídeos 43

4.4.1 Subcultivo das amostras destinadas ao sequenciamento $\quad 43$

4.4.2 Extração do DNA 43

4.4.3 PCR para amplificação do gene 16S rRNA 44

4.4.4 PCR para amplificação do gene da urease 45

4.4.5 Detecção do produto amplificado 45

4.4.6 Purificação e quantificação do DNA para sequenciamento $\quad 46$

4.4.7 Sequenciamento 46

4.4.8 Alinhamento e construção de árvore de similaridade 46

4.5 Avaliação dos fatores de virulência de Ureaplasma diversum 47

4.5.1 Presença de cápsula 47

4.5.2 Atividade de fosfolipase C 47

4.5.3 Atividade de $\lg A$ protease $\quad 48$

4.5.4 Adesão e invasão 49

4.5.4.1 U. diversum e células Hep-2 49

4.5.4.2 Marcação e quantificação dos ureaplasmas $\quad 50$

4.5.4.3 Inoculação dos ureaplasmas em células Hep-2 (BASEMAN et al., 1995) 50

4.5.4.4 Marcação das células Hep-2 51

4.4.4.5 Verificação de invasão nuclear 51

4.5.4.6 Microscopia Confocal 51

4.5.4.7 Teste da Gentamicina 52

5 RESULTADOS 53

5.1 Subcultivo das cepas e estirpes de U. diversum 53

5.2 Variabilidade no gene 16S rRNA 53

5.2.1 PCR do gene 16S rRNA 53

5.2. 2 Análise intra-específica do gene 16S rRNA 54 
5.3 PCR do gene da Urease

5.4 Avaliação dos fatores de virulência de Ureaplasma diversum $\quad 60$

5.4.1 Presença de cápsula

5.4.2 Fosfofolipase C

62

5.4.3 Atividade de $\lg A$ protease

64

5.4.4 Invasão e adesão em células Hep-2

6 DISCUSSÃO

7 CONCLUSÕES

REFERÊNCIAS 


\section{INTRODUÇÃO}

A eficiência da produção bovina pode ser caracterizada por altas taxas de natalidade e baixas taxas de mortalidade. A taxa de natalidade do rebanho é influenciada pela taxa de concepção, índice de mortalidade embrionária e abortamento. Os distúrbios reprodutivos múltiplos em fêmeas denomina-se de infertilidade, sendo caracterizada pelo estro fraco ou ausente, volta repetida ou estro a intervalos regulares ou variáveis e a uma tendência à parição prematura, natimortos ou abortamentos (IDE, 1970; ANDREWS, 1992).

Os micoplasmas incluem-se entre os agentes causadores de infecções no trato reprodutivo dos animais (SHEPARD et al., 1974; RUHNKE et al., 1978; CARDOSO et al., 2000). Atualmente, molicute é termo utilizado genericamente para designar cerca de 200 espécies da Classe dos Mollicutes, composta por cinco ordens, seis famílias e 14 gêneros. Nos gêneros Mycoplasma, Ureaplasma e Acholeplasma encontram-se, na grande maioria, as espécies que habitam os animais como comensais, saprófitos ou patógenos (RAZIN e BARILE, 1985).

A virulência destas bactérias é esclarecida melhor em algumas espécies, porém desconhecida em outras. A competição por nutrientes, produção de metabólitos, enzimas e outros compostos e a necessidade por lipídios, pirimidinas e purinas pré-formadas nas células hospedeiras constituem-se entre os fatores de patogenicidade. Existem espécies que aderem, invadem ou mesmo provocam fusão com células, ocorrendo, neste contexto, mimetização, modulação ou evasão da resposta imune do hospedeiro. A preferência por epitélios, principalmente do trato respiratório ou urogenital, permite considerálos parasita de superfície (ROTTEM, 2002).

A presença de micoplasmas no trato reprodutivo de animais sadios ou doentes constitui-se tema controverso. Entretanto, dados sobre infecções naturais ou experimentais comprovam que espécies consideradas no passado como comensais, são consideradas, atualmente, patogênicas (DOIG et al., 1979; REID et al., 1989; RUHNKE e ROSENDAL, 1994; SARDERSON e CHENOWETH, 1999). 
No gênero Ureaplasma, são descritas atualmente duas espécies de origem humana e cinco de origem animal. Estima-se que estas bactérias possuam uma a duas cópias dos genes rRNA no genoma (BOATMAN et al.,1979). No metabolismo, destaca-se a urease, que hidrolisa a uréia e caracteriza o gênero Ureaplasma. $U$. diversum possui genoma de aproximadamente $750 \mathrm{Kpb}$ e filogeneticamente está próximo às espécies de Acholeplasma e Spiroplasma. U. diversum foi isolado pela primeira vez em 1967 do trato reprodutivo bovino por Taylor-Robinson et al. (1967). Posteriormente verificou-se que estes microrganismos habitavam o trato genital de fêmeas e machos sem distúrbios reprodutivos. Doig et al. (1980), experimentalmente, reproduziram quadros de vulvite granular bovina $\mathrm{e}$ demonstraram a importância deste agente para os bovinos. A inoculação de cepas de $U$. diversum na glândula mamária de bovinos e ovinos evidenciou significativas diferenças na virulência de algumas cepas (BALL e MACKIE, 1985; HOWARD et al., 1973).

Os ureaplasmas bovinos são considerados molecularmente $e$ sorologicamente heterogêneos. Buzinhani et al. (2007a, 2007b) observaram que isolados de $U$. diversum apresentaram heterogeneidade quando analisadas pelas técnicas de PFGE e AFLP.

A patogenicidade de $U$. diversum é pouco conhecida. Experimentalmente, este microrganismo não causou alterações ultraestruturais na mórula bovina (BRITTON et al., 1987), mas confirmou-se a presença de ureaplasmas na superfície externa da zona pelúcida, podendo ser transmitido para recipientes durante a transferência de embrião (BRITTON et al., 1989). Smits et al. (1994) sugeriram que U. diversum altera a integridade de células do oviduto, contribuindo para a deficiência de implantação do embrião bovino e seu desenvolvimento. Quando $U$. diversum cresce em células de oviduto, ocorre a ciliestase, desciliação e descamação do epitélio (STALHEIM et al., 1976). A toxicidade da amônia liberada pela hidrólise da uréia pode ser considerada fator de virulência, provavelmente por afetar tecidos adjacentes. A patogenicidade de $U$. diversum é pouco conhecida e o presente estudo tem 0 objetivo em contribuir neste aspecto destas bactérias. 


\section{REVISÃO DE LITERATURA}

\subsection{Características gerais dos molicutes}

O cultivo de micoplasma foi descrito inicialmente por Edmond Norcard e Emile Roux em 1898, que estudavam a pleuropneumonia bovina, doença observada há mais de um século na Europa e na África. O agente etiológico era filtrável, semelhante aos vírus que haviam sido recentemente descobertos. No entanto, estes microrganismos cresciam em meios de cultura como as bactérias. No decorrer do tempo, microrganismos semelhantes, isolados de humanos e de animais, foram descritos por outros pesquisadores e denominados de PPLO - "Pleuropneumonia-Like Organisms" (MOROWITZ, 2002; RAZIN e JACOBS, 1992).

O nome "micoplasma" foi usado para denominar os microrganismos da Classe Mollicutes, mas sugeriu-se o uso do termo molicutes como nome trivial, para designar qualquer microrganismo desta classe. O termo micoplasma refere-se atualmente apenas aos membros do gênero Mycoplasma. A Classe dos Mollicutes é composta por cinco ordens (Mycoplasmatales, Entomoplasmatales, Acholeplasmatales, Anaeroplasmatales e Incertae sedis), seis famílias (Mycoplasmataceae, Entomoplasmataceae, Spiroplasmataceae, Acholeplasmataceae, Anaeroplasmataceae e Erysipelothrichaceae) e 14 gêneros (Mycoplasma, Eperythozoon, Haemobartonella, Ureaplasma, Entomoplasma, Mesoplasma, Spiroplasma, Acholeplasma, Anaeroplasma, Asteroplasma, Erysipelothrix, Bulleidia, Holdemania e Solobacterium) (BERGEY'S Manual of Determinative Bacteriology, 2001).

Os molicutes estão amplamente distribuídos no Reino Animal como comensais, saprófitos ou patógenos (RAZIN e BARILE, 1985). Estes agentes estão associados a diversas doenças cujos sinais clínicos podem ser agudos, porém, freqüentemente apresentam caráter crônico (JASPER, 1967; SAHU e YEDLOUTSCHNIG, 1994; TULLY, 1993). Nas diferentes espécies animais, os molicutes são potenciais causadores de distúrbios no sistema respiratório, urogenital, glândula mamária, articulações, sistema nervoso e conjuntiva ocular 
(NASCIMENTO et al., 1986; KIRKBRIDE, 1987; STIPKOVITS et al., 1993; GARCIA et al., 1996).

Aproximadamente 200 espécies de Mollicutes são conhecidas, mas apenas um número reduzido, principalmente do gênero Mycoplasma, é considerado como patógeno de animais. As espécies patogênicas nos animais de produção causam grandes perdas econômicas. Algumas espécies, apesar de classificadas como comensais das regiões mucosas, são consideradas importantes na medicina veterinária (FREY, 2002).

A maioria das espécies de micoplasmas conhecida é de origem animal e, portanto, existe grande diversidade na relação parasito-hospedeiro neste campo da micoplasmologia (SIMECKA et al., 1992). Estas bactérias também infectam animais silvestres, de experimentação e domésticos (RAZIN, 1995). A natureza dos molicutes tem representado um desafio na compreensão da sua biologia, classificação e taxonomia. Por muito tempo, os micoplasmas foram considerados vírus, devido a capacidade de transpor filtros que bloqueavam a passagem de bactérias (RAZIN, 1992).

Os molicutes são microrganismos de vida livre, distintos de outras bactérias devido ao seu pequeno tamanho, total ausência de parede celular (RAZIN, 1995) e por apresentarem requerimentos nutricionais diferenciados quando comparados à maioria das bactérias de interesse veterinário e humano. Aminoácidos, nucleotídeos e esteróis exógenos são utilizados para seu crescimento in vitro. O esterol, presente no soro ou células do hospedeiro é incorporado pela membrana da maioria das espécies. Este composto contribui na fluidez necessária à membrana e confere resistência parcial à lise osmótica. Nos meios de cultura o soro animal é usualmente suplementado (RUHNKE e ROSENDAL, 1994). A membrana dos micoplasmas tem composição semelhante às das eubactérias e está exposta ao ambiente, com exceção de poucas espécies que possuem glicocálice (WIESLANDER et al., 1992).

Os micoplasmas são considerados os menores microrganismos de vida livre e não possuem parede celular, que desapareceu por evolução degenerativa (RAZIN e TULLY, 1983; NEIMARK, 1986). Apesar da ausência de parede celular, sua forma é geralmente ovóide. Os micoplasmas, em geral, aproximam-se das dimensões dos maiores vírus $(0,2$ a $0,4 \mu \mathrm{m})$. Poucas espécies, entretanto, apresentam-se espiraladas, atingindo cerca de $100 \mu \mathrm{m}$. A 
forma filamentosa é "multinucleada", podendo ocorrer em determinados momentos da multiplicação celular, pela falta de sincronia entre a septação na divisão celular e a replicação do DNA (Figura 1). Assim, além da fissão binária, a partir dos filamentos, formam-se cadeias ou conjuntos de pequenas células de micoplasma viáveis que se desprendem, e, sob pressão em filtros, podem transpor a porosidade de 0,22 $\mu \mathrm{m}$ (TIMENETSKY e METTIFOGO, 2002; BASEMAN e TULLY, 1997).

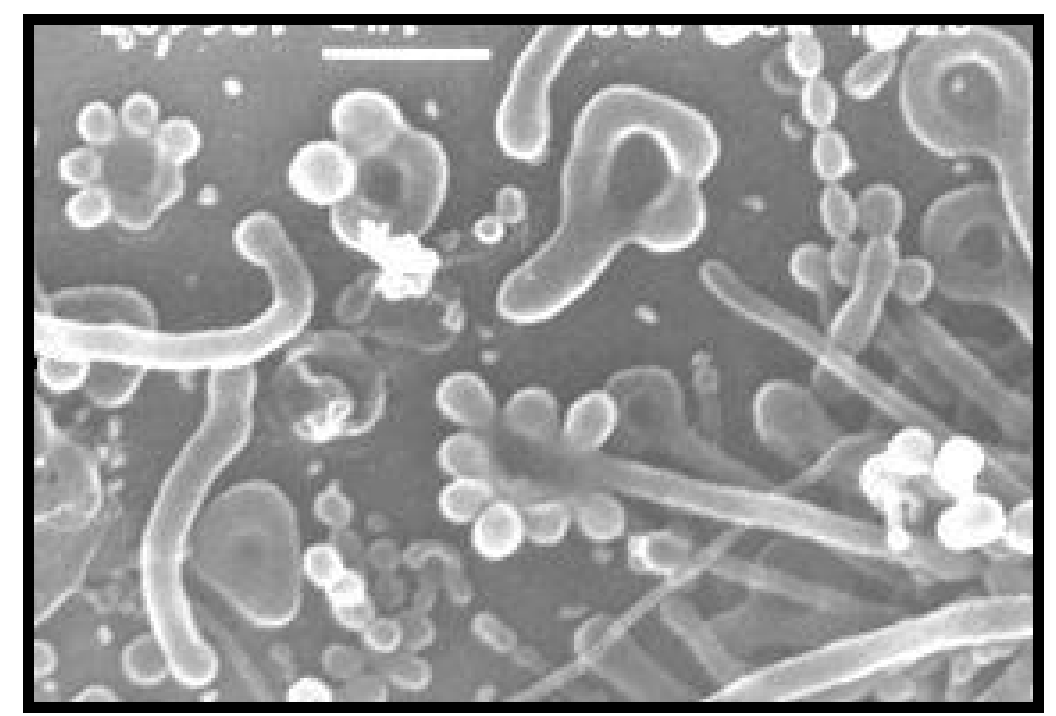

Figura 1. Morfologia dos micoplasmas. Foto cedida pelo Prof. Dr. Michael Rabinovich.

Várias características adaptativas existem nestes microrgansmos para a sua transmisão e subxistencia em diferentes nichos dos hospedeiros. Localizam-se principalmente nas células de mucosas e com potencial de invasão (DYBVIG e VOELKER, 1996). As mutações têm sido mencionadas como estratégia de sobrevivência, que podem ter ocorrido em função da evolução associada a perdas genômicas (DAVID et al., 2002).

Apesar de não possuírem flagelos, algumas espécies exibem deslizamento sobre superfícies líquidas ou apresentam contração celular. Alguns micoplasmas possuem um tipo de estrutura ou prolongamento polar em sua superfície, onde há alta concentração de moléculas de adesão, que permitem a sua aderência à célula hospedeira (RAZIN, 1992). Acredita-se que estas estruturas, em algumas espécies como Mycolasma penetrans, de origem humana, estejam envolvidas na invasão celular (LO et al., 1992). 
O genoma circular de dupla fita dos Mollicutes é o menor conhecido entre os procariotos. Membros desta classe têm sido divididos em dois grupos, de acordo com o tamanho do genoma; um é composto pelos gêneros Mycoplasma e Ureaplasma, que possui cerca de 770 a $800 \mathrm{Kpb}$, e o outro formado pelos gêneros Acholeaplasma, Spiroplasma e Anaeroplasma, que possuem o dobro do genoma (HEREMANN, 1992).

O genoma reduzido justifica a síntese de poucas proteínas e limitadas atividades metabólicas. Os Mollicutes são nutricionalmente exigentes e portanto, dificultam o seu estudo (MILES e NICHOLAS, 1998). Os genomas são caracterizados por possuírem baixo conteúdo de guanina e citosina $(C+$ G), variando de 24 a 33 mol\%, com exceção de algumas poucas espécies, que possuem cêrca de $41 \mathrm{~mol} \%$. O conteúdo do DNA tem sido utilizado entre os testes requeridos para a definição de novas espécies de Mollicutes (RAZIN, 1992).

As peculiares propriedades dos micoplasmas levaram a uma atenção especial quanto a sua filogenia. De acordo com um modelo, os micoplasmas representam microrganimos sobreviventes de descendentes primitivos. Um segundo modelo acredita que os micoplasmas surgiram de uma evolução degenerativa de bactérias gram positivas, mais especificadamentes dos clostridios. Enquantos os dados obtidos do sequenciamento do rRNA e tRNA fortalecem a segunda teoria, a diversidade genotípica e fenotípica dos microrganimos pertencentes a esta classe e suas peculiar propriedades, revelam a idéias de que os molicutes constitutem um grupo de situação rápida de evolução (FADIEL et al., 2007).

Os molicutes pertencem a um braço da árvore filogenética da bactéria Gram-positiva com baixo conteúdo C+G (MANILOFF, 1992). O ancestral dos molicutes originou-se do braço filogenético do Streptococcus, há cerca de 600 milhões de anos atrás, provavelmente de um microrganismo com genoma aproximado de $2000 \mathrm{Kpb}$. A árvore filogenética posteriormente originou dois braços maiores, relacionados aos microrganismos com cerca de 450 milhões de anos atrás, possivelmente a partir de um microrganismo com genoma de 1700 a $2000 \mathrm{Kpb}$ (MANILOFF, 2002). Um dos braços deu origem aos Anaeroplasma, Asteroplasma e Acholeplasma e o outro ao Spiroplasma, Entomoplasmas e Mycoplasmas. O Phytoplasma provavelmente originou-se do 
Acholeplasma e o Ureaplasma do Mycoplasma. A relação de citosina e guanina $(\mathrm{C}+\mathrm{G})$ no DNA de procariotos é um efetivo parâmetro taxonômico e está incluído entre os testes para a definição de novas espécies de Mollicutes. Seqüências de nucleotídeos proporcionam valiosas informações na determinação das relações genéticas entre diferentes bactérias e servem como base para o estabelecimento de espécies (RAZIN, 1992).

Embora os molicutes possuam pequeno genoma, que facilitam seu seqüenciamento, existem apenas informações parciais obtidas pelas técnicas de hibridização de DNA-DNA e DNA-RNA, perfil de clivagem genômica e mapas genéticos. Seqüências dos genes $16 \mathrm{~S}$ rRNA, de aproximadamente 40 espécies de molicutes, estão disponibilizadas no GenBank e contribuem na solução de problemas taxonômicos (WEISBURG et al., 1989). A compreensão da variabilidade genotípica inter-espécies e intra-espécie é importante no estudo da patogenicidade e na taxonomia (RAZIN, 1992).

Os molicutes parecem apresentar uma única DNA polimerase, em contraste às três DNA polimerases encontradas na $E$. coli e outros procariotos. Ainda não está claro, mas houve uma perda da atividade de exonuclease da DNA polimerase que pode proporcionar um marcador bioquímico indicativo de divergências entre os molicutes e eubactérias (MANILOFF, 1983). Achados recentes revelam a presença de apenas uma DNA polimerase em $M$. orale e $M$. hyorhinis, não apresentando a atividade de exonuclease $3^{\prime}-5^{\prime}$, que pode determinar problemas na mecanismos de profreeding relacionados a replicação. Entretanto os espiroplasmas apresentam três DNA polimerases, como em E. coli. Atividades fotoreativas e mecanismos de reparo foram observados em A. laidlawii, mas não em M. gallisepticum (DYBVIG et al., 1992).

Existem apenas uma a duas cópias de genes rRNA, sendo que a maioria das bactérias possuem cinco a dez cópias. Isto pode facilitar estudos sobre 0 controle de mecanismos de síntese do rRNA. Existem várias razões para focar atenção nestes genes como a obtenção de produtos altamente conservados, que servem como marcadores filogenéticos e facilitam a seleção e clonagem de sondas para detecção e identificação dos molicutes (RAZIN, 1985).

As RNA polimerases dos molicutes, como nas arqueobactérias, são resistentes a rifampicina. No entanto, as estruturas das subunidades se 
assemelham as eubactérias. As sequencias genéticas das regiões promotoras e terminadoras são semelhantes as eubactérias em poucos molicutes (GADEAU et al., 1986).

Os ribossomos dos micoplasmas são compostos por sequencias altamente conservadas, que podem ser utlizadas como marcadores filogenéticos. Estas moléculas apresentam estrutura e composição semelhantes a outras eubactérias, sendo os genes relacionados a esta proteínas apresentam alta concentração de A+T (71 mol\%). A porção $5 S$ rRNAs dos micoplasmas é menor que em outros procariontes, enquanto a porção 16S rRNA apresenta seqüências de nucleotídeos ausentes em outras bactérias (MUTO et al., 1983).

Os mollicutes pode ser também divididos em fermentadores e nãofermentadores. Os fermentadores produzem ácidos por meio da metabolização de glicose e de outros carboidratos, diminuindo o pH do meio de cultivo, e os não- fermentadores possuem a via da arginina-deidrolase como modo de obter ATP, aumentando o pH (RAZIN, 1978, 2004). Quando ambas as vias ocorrem, os ácidos produzidos da glicólise podem mascarar a alcalinização do caldo causada pela hidrólise da arginina (OLSON et al., 1993). Alguns micoplasmas não metabolizam açúcares e arginina, mas são capazes de oxidar ácidos orgânicos (lactato e piruvato) a acetato e $\mathrm{CO}_{2}$ (MILES et al., 1994). Os ureaplasmas requerem uréia (único entre os organismos vivos) para produzir ATP, hidrolizando este composto e produzindo amônia (RAZIN, 2004; BASEMAN e TULLY, 1997).

O estudo das exigencias nutrucionais dos molicutes contribui no seu isolamento e caracterização fenotípica. Mas a variação e a adaptação genética também é detectada (MILES, 1992). A definição de requerimentos orgânicos (aminoácidos, precursores de ácidos nucléicos, lipídeos, carboidratos, vitaminas e outros compostos) para o crescimento está relacionada à vias metabólicas de cada gênero. Os requerimentos inorgânicos são menos estudados e os resultados são freqüentemente difíceis de interpretar. Os elementos mais importantes são: $P(4,2 \%), \mathrm{Mg}^{2+}(0,6 \%), \mathrm{K}(1,2 \%)$ e $\mathrm{Fe}^{2+}$ $(0,02 \%)$. Outros elementos, principalmente metais, podem ser necessários em pequenas quantidades (MILES, 1992). 
A temperatura de aproximadamente $37^{\circ} \mathrm{C}$ é indicativa do "habitat" natural dos molicutes que corresponde à dos mamíferos e aves. Spiroplasmas, que infectam plantas, têm temperatura ótima de crescimento 30 a $32{ }^{\circ} \mathrm{C}$ e os Anaeroplasmas, podem crescer a temperaturas de até $49 \stackrel{\circ}{\circ} \mathrm{C}$ (GARDELLA e DEL GIUDICE, 1983).

O crescimento e sobrevivência dos molicutes em meio de cultura são dependentes do $\mathrm{pH}$. Para espécies originárias de plantas e vertebrados, o pH ótimo é de 7,4 e o crescimento ocorre entre pH 6,5 a 8,0. Os ureplasmas são exceções, sendo o pH ótimo de 5,5 a 6,0 e seu crescimento inibido em pH acima de 7,5 (RAZIN et al., 1977). A inibição do crescimento pode ocorrer pela excessiva produção de ácidos ou álcalis gerado pelo metabolismo microbiano primário.

A pressão osmótica, durante o crescimento de algumas espécies de Mycoplasma e o Acholeplasma laidlawii, em meio líquido ou sólido, foi próximo a $10 \mathrm{~atm}$ com variações entre os diferentes gêneros e espécies, atingindo valores de 6,5 a 32 atm (LEACH, 1962). O estabelecimento da osmolaridade para o crescimento de algumas espécies é significativa para pesquisa destas bactérias (RAZIN et al., 1977). A umidade e as condições atmosféricas de incubação são dependentes do $\mathrm{pH}$, nutrientes, capacidade de oxidação e redução destes compostos.

O crescimento destes microrganismos em meio sólido é expresso em pequenas colônias de 50 - $500 \mu \mathrm{m}$ de diâmetro, usualmente em forma de "ovo frito" (Figura 2), que são visualizadas com o auxílio de microscópio estereoscópio. Em meio líquido, o crescimento geralmente não causa turvação, provocando somente alteração no $\mathrm{pH}$, revelado por um indicador presente no meio de cultura (RAZIN, 1995). 


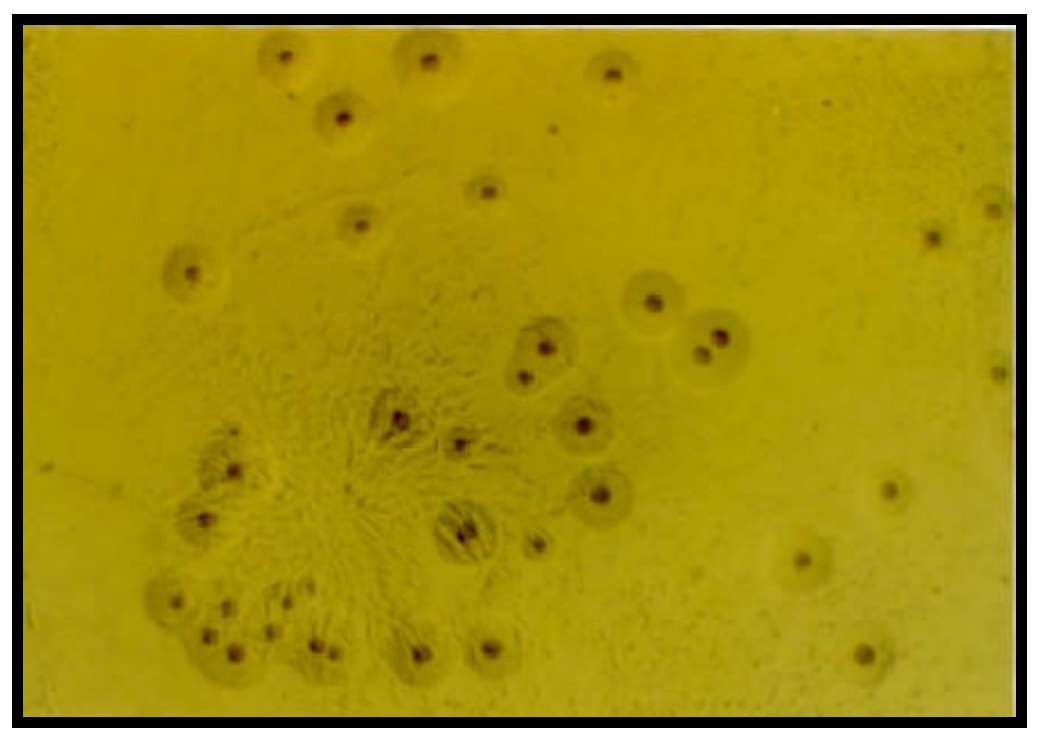

Figura 2. Crescimento em meio sólido como colônias em forma de "ovo frito". Aumento de 100X.

Em geral, os molicutes possuem aproximadamente $0,3 \mu \mathrm{m}$ de diâmetro e $98 \mu \mathrm{m}$ de extensão. Freqüentemente, os molicutes apresentam pleomorfismo, podendo ser cocóide e filamentoso (CARSON et al., 1992). Em muitas espécies, há evidencias de formação de filamentos, especialmente durante a fase exponencial inicial. Rodwell e Mitchell (1979) concluíram que crescimento filamentoso ocorre em quase todos molicutes sob condições adequadas e 0 aumento no tempo da cultura pode favorecer a mudança na forma. A morfologia também pode ser afetada pela qualidade nutricional, variação osmótica do meio e pelo conteúdo de lipídio da membrana (MILES, 1992).

Muitas espécies de micoplasmas expressam variavelmente na superfície celular antígenos estruturalmente heterogêneos. Modificações nos genes que codificam moléculas de adesão capazes de gerar mudanças antigênicas das moléculas de superfície, indicando um importante mecanismo de patogenicidade por mimetizar e evadir-se da resposta imune. Estas variações podem alterar os mecanismos de colonização e penetração dos micoplasmas nos tecidos (NICOLSON et al., 1999).

Os molicutes exibem estrita relação aos hospedeiros e especificidade a tecidos e órgãos, que reflete as suas características nutricionais e adaptação parasitária. Estas bactérias podem ocorrer em hospedeiros e tecidos diferentes de seu "habitat" normal. O "habitat" primário em humanos e animais são as 
superfícies mucosas do trato respiratório e urogenital, olhos, canal alimentar, glândulas mamária e articulações (RAZIN, 1992).

Os Anaeroplasmas, anaeróbios obrigatórios, são encontrados apenas no rúmen de bovinos e ovinos. Spiroplasmas e Phytoplasmas são encontrados no intestino, hemocele e glândula salivar de artrópodes (RAZIN et al., 1998). Os Spiroplasmas e Phytoplasmas podem ser inoculados, via aparelho sugador de insetos, no floema de plantas causando doenças (WHITCOMB e TULLY, 1989).

Os fatores de virulência dos molicutes são pouco conhecidos. No entanto, acredita-se existir competição, entre as células hospedeiras e os microrganismos, por substratos metabólicos como os precursores de lipídeos, pirimidinas e purinas pré-formadas. Os molicutes que infectam humanos e animais são consideradas como parasitas de superfície, pois aderem a mucosa do trato respiratório e urogenital. Este processo de aderência pode estar relacionado a dificuldade de eliminação destes parasitas por secreções mucosas ou urina (RAZIN et al., 1998). Diversas espécies de micoplasmas dependem da adesão ao tecido hospedeiro para colonizarem e infectarem células, sendo esta considerada como importante fator de virulência. As cepas mutantes deficientes em aderência são avirulentas (RAZIN e JACOBS, 1992; BASEMAN e TULLY, 1997).

Estruturas polares denominadas "bleb" ou "tip" foram descritas em algumas espécies de micoplasma. Nas espécies mais estudadas, verificou-se que esta tem função de aderência, invasão e/ou motilidade por deslizamento. Nestas estruturas localizam-se proteínas relacionadas com a adesão, conhecidas como adesinas, sendo uma denominada de proteína P1 (INAMINE et al., 1988) e outra de P30 (DALLO et al., 1990b), que encontram-se densamente agrupadas na extremidade desta estrutura. As espécies virulentas de $M$. pnemoniae apresentam estas adesinas, que são responsáveis por promoverem a citoaderência, bem como, induzir forte resposta imunológica (BALISH e KRAUSE, 2000; RAZIN e JACOBS, 1992).

Além de aderir, alguns micoplasma podem invadir células não fagocíticas. Esta habilidade tem sido intensivamente estudada em diversos micoplasmas, como $M$. penetrans, $M$. fermentans, $M$. pneumoniae, $M$. genitalium e $M$. gallisepticum, que demonstraram sob determinadas circunstâncias, residir no 
interior de células (ROTTEM, 2002). A entrada dos micoplasmas em células pode ser considerada uma estratégias para sua persistência nos hospedeiros imunocompetentes. Além disto, este processo pode permitir acesso a nutrientes essenciais e proteção contra o sistema imune. A invasão pode ter papel crucial no estabelecimento de nichos e desenvolvimento de infecções sistêmicas pela transposição da barreira mucosa, além de dificultar a ação de anticorpos e antibióticos (ANDREEV et al., 1995).

A invasão celular envolve processos complexos, tanto das bactérias quanto das células hospedeiras. Esta interação pode ser devido a associação entre adesinas e receptores celulares. Provavelmente as moléculas que facilitam o processo de adesão terão efeito na invasão, entretanto, somente a aderência não é suficiente para promover invasão (SHAW e FALKOW, 1998).

Os micoplasmas apresentam interação com o hospedeiro, principalmente com o sistema imune inato e adquirido (GLASS et al., 2000). Estes microrganismos causam uma série de reações imunológicas que conduzem a alterações patológicas (NICOLET, 1986). A ausencia da parede celular dos molicutes permite o contato íntimo com as células hospedeiras. Na microscopia eletrônica e sob condições apropriadas observou-se a fusão destas bactérias com células hospedeiras. Diversos estudos verificaram que este processo é dependente do conteúdo de colesterol da membrana dos micoplasmas (ROTTEM, 2002). Durante o processo de fusão observou-se a produção de proteases, fosfolipases e nucleases dentro da célula hospedeira afetando suas funções normais. Estas enzimas, combinadas com radicais superóxido podem levar ao efeito clastogênico. Diversos estudos relatam alterações ou fragmentações cromossomais e/ou morfológicas em células infectadas por espécies de micoplasmas (CUNHA et al., 1997; CHERNOV et al., 1995).

Outro fator relacionado as infecções micoplasmáticas é a possível indução de apoptose. Células infectadas por $M$. hyorhinis apresentaram fragmentação de DNA, um indicativo de apoptose (PADDENBERG et al., 1996). As altas concentrações de metabólitos durante a aderência dos micoplasmas nas células hospedeiras propiciam o processo de dano tecidual (YOU et al., 2006).

Infecções causadas por micoplasmas raramente são agudas, e geralmente seguem para a cronicidade. A patogenicidade dos micoplasmas 
ainda não estão bem esclarecidas, mas acredita-se que os danos relacionados as infecções em humanas ou animais sejam mais prováveis pela respostas imune e inflamatórias do hospedeiro, do que diretamente pelo efeito citotóxico destes microrganismos. No entanto, potentes toxinas estão associadas aos micoplasmas e produtos do seu metabolismo, como peróxido de hidrogênio e radicais superóxidos, que têm sido apontados pelos seus efeitos oxidativos às membranas das células hospedeiras (RAZIN, 2004). A urease presente nos ureaplasmas pode ser considerada um fator de virulência importante, devido a liberação da amônia produzida pela hidrólise da uréia.

\subsection{Micoplasmas animais}

O primeiro micoplasma foi relatado em 1898, M. mycoides subsp. Mycoides, causador da CBPP (NOCARD e ROUX, 1898). Posteriormente, micoplasmas e ureaplasmas têm sido isolados de animais domésticos, silvestres e de laboratório, portanto, são economicamente importantes na agropecuária e pesquisa biomédica. As infecções estão usualmente associadas ao pulmão, trato genito-urinário, articulações e outros tecidos. As infecções estão associadas aos tratos respiratório e genito-urinário, conjuntivas, articulações e outros tecidos. Desta forma, patogenia, diagnóstico e tratamento de doenças animais causadas por molicutes continuam sendo bastante enfatizados (SIMECKA et al., 1992).

Ratos e camundongos apresentam micoplasmose respiratória murina (MRM) causada pelo M. pulmonis. A doença normalmente tem caráter crônico, com diferenças na virulência das estirpes e susceptibilidade dos animais que podem resultar na forma severa ou apenas subclínica. A morbidade ou mortalidade, resultante de infecções, pode afetar drasticamente pesquisas biomédicas. $M$. pulmonis, $M$. arthritidis, $M$ muris, $M$. neurolyticum e $M$. collis foram isolados de diferentes sítios anatômicos de roedores e podem ser relacionados a doenças genitais, artrite e conjuntivite (DAVIDSON et al., 1994).

Os micoplasmas são importantes patógenos aviários, responsáveis por doenças respiratórias e articulares, acarretando grandes perdas econômicas na avicultura brasileira e mundial. Esta micoplasmose é considerada como um dos principais problemas sanitários na cadeia produtiva avícola, juntamente com a 
doença de New Castle, coccidiose, colibacilose, doença de Gumboro e a salmonelose. Dentre as 20 espécies isoladas de aves, M. gallisepticum, $M$. synoviae, $M$. meleagridis e $M$. iowae são considerados os principais agentes patogênicos para galinhas e perus. Estas espécies, contribuem em perdas econômicas importantes devido ao decréscimo na taxa de crescimento e no ganho de peso, perdas por condenações de carcaças, devido à doença respiratória crônica em frangos de corte, bem como a redução na produção e eclodibilidade de ovos, além dos custos com profilaxia e uso de drogas terapêuticas (HOERR et al., 1994; MOHAMMED et al., 1987).

A Pneumonia Enzoótica Suína (PES) encontra-se disseminada mundialmente causando grandes perdas econômicas na suinocultura. $O$ agente primário desta enfermidade é o $M$. hyopneumoniae. A PES é uma doença multifatorial, sua gravidade e importância econômica nas granjas estão associadas a variações climáticas, sistema de produção e manejo (STÄRK et al., 2007). A doença caracteriza-se por baixa mortalidade e alta morbidade. $O$ sinal clínico mais comum é tosse seca crônica, entretanto, muitos animais não manifestam sinais aparentes. $M$. hyorhinis e $M$. hyosynoviae também são espécies patogênicas para suínos, no entanto, a sua participação na PES ainda não bem esclarecida (ARMSTRONG, 1994).

Ovinos e caprinos são acometidos, com algumas exceções, pelas mesmas espécies de micoplasmas. $M$. agalactiae causa a síndrome da agalaxia em ovelhas e cabras, classificadas como uma das mais importantes doenças causadas por micoplasmas. M. capricolum também causa semelhante agalaxia e doenças septicêmicas fatais em animais jovens. Pleuropneumonia contagiosa caprina (M. mycoides subsp. mycoides LC), septicemias, poliartrites em caprinos (M. mycoides subsp. capri) e ceratoconjuntivites (M. conjuntivae) são algumas das doenças causadas pelos micoplasmas nestes animais (ROSENDAL, 1994). Os ureaplasmas isolados de ovinos foram estudados por Livingston et al. (1978, 1982) e Ball et al. (1985) por meio de inoculações experimentais, sendo o sorotipo IX relacionado como responsável por infertilidade e aborto em ovelhas. Estes ureaplasmas não receberam ainda a designação de espécie, sendo apenas conhecidas suas características sorológicas. No entanto, o conteúdo de DNA e de polipeptídeos indicaram 
maior similaridade com U. diversum (HOWARD et al., 1978; KOTANI et al., 1980; HOWARD e POCOCK, 1983).

Os micoplasmas podem ser habitantes normais das vias aéreas superiores de alguns bovinos. Diversas espécies estão envolvidas na pneumonia de bezerros e podem ser consideradas como agentes primários de infecções respiratórias (SIMECKA et al., 1992). Rebhun et al. (2000) descreveram o isolamento freqüente de micoplasmas em surtos de pneumonia aguda e crônica em bezerros e esse microrganismo pode estar associado em até $50 \%$ das endemias investigadas. Entretanto, raramente é o único patógeno isolado (RADOSTITS, 2002). Em países onde a Pleuropneumonia contagiosa bovina causada por M. mycoides subsp. mycoides SC é ausente, $M$. dispar e M. bovis são os principais agentes etiológicos identificados (REBHUN et al., 2000). O trato genital de bovinos também pode ser colonizado por molicutes. M. bovigenitalium causa infertilidade, endometrite, vulvovaginte granular, vesiculite seminal necrotizante e diminui a motilidade de espermatozóides. $M$. bovis está relacionado a quadros de endometrite, salpingite e aborto e $M$. canadense é freqüentemente isolado do trato genital de touros $\mathrm{e}$ esporadicamente de fetos abortados. Além destas espécies, $U$. diversum também é considerado importante nos disturbios relacionados ao trato reprodutivo bovino (RUHNKE e ROSENDAL, 1994).

As doenças crônicas associadas às micoplasmoses são raramente reconhecidas como doenças emergentes em animais silvestres (BROWN et al., 2005). Diversos micoplasmas estão associados a animais em todas as classes de vertebrados. Estas bactérias, comumente, são espécie-específicas, porém algumas apresentam a capacidade de infectar diferentes hospedeiros (RAZIN, 1995). M. gallisepticum, patógeno respiratório importante na avicultura, já foi descrito acometendo conjuntivite em aves silvestres. A maioria das espécies de micoplasmas isolados em humanos têm sido descobertas em primatas nãohumanos. Devido a este fato, foi sugerido por Del Guiduce et al. (1971) classificar estas espécies como relacionadas a primatas, o que engloba humanos e macacos. Poucas espécies de molicutes de origem animal foram isolados de humanos, mas causaram doença em indivíduos imunossuprimidos (PITCHER e NICHOLAS, 2005). 


\subsection{Ureaplasma diversum}

Os ureaplasmas são microrganismos pleomórficos. A sua morfologia dependente da cepa, do tempo da cultura e do método de observação. Estruturas relacionadas a motilidade não foram observadas. São bactérias, microaerófilas e possuem temperatura ótima de crescimento de $37^{\circ} \mathrm{C}$, mas podem crescer entre $22^{\circ} \mathrm{C}$ e $42^{\circ} \mathrm{C}$. Em meio sólido produzem colônias de 15 a $60 \mu \mathrm{m} \mathrm{em} \mathrm{pH}$ ideal de 6,0. Todos ureaplasmas hidrolizam uréia com a produção de amônia. São frequentemente encontrados no trato respiratório e urogenital de humanos e espécies animais. $A$ mol\% de $G=C$ no DNA dos ureaplasma humanos é cerca de 26,9 a 28,0 e na espécie bovina é de 29,7 a 30,2 (BERGEY'S, 2001)

Os ureaplasmas de origem bovina foram isolados pela primeira vez do trato reprodutivo bovino em 1967 por Taylor-Robinson et al., obtendo incidência de $11 \%$ de isolamento da vagina de vacas aparentemente sadias. Estudos subseqüentes demonstraram que estes microrganismos eram isolados do trato genital de fêmeas e machos que não apresentavam distúrbios reprodutivos. Por esta razão, os ureaplasmas foram descritos como agentes não patogênicos por muitos anos, acreditando-se que pertenciam à microbiota residente do trato reprodutivo. Posteriormente, Doig et al. (1980a e 1980b), por meio de estudo experimental com inoculação vulvar, reproduziram quadros de vulvite granular bovina e confirmaram a importância deste agente no trato reprodutivo. Resultados da inoculação, de várias estirpes de $U$. diversum na glândula mamária de vacas e ovelhas, indicaram a existência de diferenças na virulência de algumas cepas, justificando a presença destes microrganismos no trato reprodutivo normal (BALL e MACKIE, 1985; HOWARD et al., 1973).

Os ureaplasmas bovinos são sorologicamente heterogêneos, sendo distinguidos com anti-soros produzidos em coelhos em três grupos sorologicamente similares, mas não idênticos. Além disto foi observado que estas bactérias são sorologicamente distintas dos ureaplasmas isolados de humanos. Por análise genômica, observou-se que o conteúdo de $G+C$ eram diferentes dos valores obtidos nas cepas de $U$. urealyticum. Estas diferenças 
sorológicas e genéticas levaram a determinação de uma espécie para os ureaplasmas isolados em bovinos: Ureaplasma diversum (OGATA et al., 1979).

O U. diversum pertence à família Mycoplasmataceae, ordem Mycoplasmatales, com genoma de aproximadamente $750 \mathrm{Kpb}$ é considerado filogeneticamente recente quando comparados às espécies de Acholeplasma e Spiroplasma. Acredita-se que os ureaplasmas também possuam uma a duas cópias dos genes rRNA em seu genoma. $U$. diversum não possui glicocálice como o U. urealyticum, mas há descrição da presença de exopolímero mais fino (BOATMAN et al., 1979). O seu metabolismo é destacado pela enzima urease que caracteriza o gênero ureaplasma.

Os ureaplamas de bovinos são sorologicamente heterogêneos, sendo classificados como grupo A, B e C. Estes microrganismos reagem diferentemente de acordo com o tipo de teste empregado, espécie animal na qual o anti-soro é produzido e possivelmente ao meio em que é cultivado. Não há associação entre o grupo sorológico e uma doença em particular, mas amostras do grupo $B$ são mais freqüentemente isoladas de casos clínicos que o grupo A e o grupo C não é isolado com freqüência (TRUSCOTT, 1983). Há indicações que o microrganismo pertencente a um grupo em particular tende a residir em determinados órgãos. Os ureaplasmas do grupo $C$ foram isolados comumente da genitália de fêmeas e o do grupo B em pulmões (HOWARD e GOURLAY, 1981), porém microrganismos dos três grupos são isolados da genitália de vacas e touros e sêmen (SAUNDERS e LUVIRA, 1986).

A patogenicidade de $U$. diversum é pouco conhecida. A vulvite granular, causada por este microrganismo foi reproduzida por meio de aspersão do agente sobre a mucosa vulvar não escarificada (DOIG et al., 1980) e por inoculação intrauterina (BALL e MACKIE, 1985). A doença pode ocorrer na forma aguda e crônica, sendo a aguda caracterizada pela presença de descarga vaginal mucopurulenta intermitente que persiste por três a 10 dias, com hiperemia da vulva e ocorrência de pequenos grânulos opacos ou vermelhos (1 - $2 \mathrm{~mm}$ de diâmetro) na mucosa vulvar adjacente ao clitóris e na parede lateral da vagina. Microscopicamente, as lesões consistem em agregações de linfócitos abaixo do epitélio escamoso. Nódulos brancos (2 - 5 $\mathrm{mm}$ ) ocorrem na parede dorso-lateral ou na comissura dorsal da vulva, em 10\% das vacas acometidas, podendo ser confundidos com vulvovaginite pustular 
infecciosa (IPV, bovine herpersvirus Group 1 infection), sendo em alguns casos seguida pela infecção viral. A infecção aguda por ureaplasma causa maior volume de descarga mucopurulenta que a IPV e as lesões são salientes e produtivas (KIRBRIDE, 1987). Rae et al. (1993) verificaram uma forte associação entre a presença de $U$. diversum com lesões vaginais. No entanto, não houve associação entre a gravidade das lesões vaginais e atividade ovariana. Os autores acreditam que $U$. diversum está relacionado com 0 processo de infertilidade, mas o papel destes microrganismos nesta enfermidade ainda não está esclarecido.

A fertilidade bovina é comprometida pelo $U$. diversum, segundo Kreplin et al. (1987). U. diversum é capaz de produzir severa placentite e alveolite fetal e pode resultar em aborto. Abortos, em rebanhos infectados, são esporádicos e ocorrem em qualquer estágio da gestação ou pode resultar no nascimento de bezerros vivos, mas fracos (HOWARD et al., 1973). Sanderson et al. (2000) observaram que vacas que apresentram-se negativas para $U$. diversum tiveram maior facilidade de fertilização do que aquelas que apresentram cultura positiva.

Inoculação na vulva e cérvix não produziram lesões no útero ou ovidutos, mas inoculações intrauterinas resultaram em salpingites e endometrites (DOIG et al., 1980a; DOIG et al., 1980b). A salpingite, em alguns casos, ocorre sem o desenvolvimento de endometrite, indicando a predileção do microrganismo pelo oviduto. As lesões produzidas não são tão severas quanto às causadas pelo $M$. bovis, mas a infecção pode resultar em um ambiente desfavorável para 0 embrião. Morte embrionária pode ocorrer aos 40-45 dias pós inseminação e o retorno ao cio por volta de 15 a 40 dias, freqüentemente acompanhado de descarga vulvar purulenta (DOIG et al., 1984). No entanto, CHELMONSKASOYTA et al. $(1994,2001)$ observaram que $U$. diversum estimula IL-1, TNF- $\alpha$ e NO em leucócitos mononucleares, mas não impede o desenvolvimento embrionário e a formação do blastocisto.

Alguns estudos demonstraram que este microrganismo não causa alterações ultra-estruturais na mórula sob condições experimentais (BRITTON et al., 1987), mas confirmam a presença de ureaplasmas na superfície externa da zona pelúcida podendo ser transmitido para recipientes durante a transferência de embrião (BRITTON et al., 1989). Smits et al. (1994) sugeriram 
a hipótese que $U$. diversum altera a integridade de células do oviduto, contribuindo para a deficiência de implantação do embrião e desenvolvimento. Quando o $U$. diversum cresce em culturas de oviduto, há primeiramente a perda da ação ciliar com posterior desciliação e descamação do epitélio (STALHEIM et al., 1976).

A amônia, liberada pela hidrólise da uréia, potente urease dos ureaplasmas, pode ser considerada um fator de virulência, provavelmente afetando tecidos adjacentes aos ureaplasmas. Outro fator de virulência é a significante diminuição da prostaglandina $\mathrm{E}_{2}$ e $\mathrm{F}_{2 \mathrm{a}}$, pelas células do endométrio, após infecção pelo $U$. diversum. As prostaglandinas são necessárias para a implantação e manutenção da gestação (KIM et al., 1994) e os ureaplasmas são capazes alterar este contexto, provavelmente pela atividade da fosfolipase A2 (LAMONT et al., 1990). Esta enzima pode liberar quantidades excessivas de ácido aracdônico, resultando na inibição dos substratos para a síntese da prostaglandina (CASSEL et al., 1993).

$U$. diversum tem sido isolado freqüentemente de animais com histórico de aborto em Ontário, Canadá, com $10 \%$ de isolamento de fetos abortados (MAXIE, 1986). Mulira et al. (1992) observaram a presença de $U$. diversum em $43,3 \%$ de vacas leiterias e em $27,1 \%$ de vacas de corte. Além disto, os autores verificaram que $\mathrm{o}$ isolamento deste molicutes em fêmeas que apresentavam lesões vulvar foi duas vezes maior que em fêmeas sadias. Petit et al. (2008) observou a presença de Ureaplasma diversum em $12 \%$ das amostras de suabe cervical e em $36 \%$ de suabe vaginal. Além disto, esta espécie foi detectada em oito dos 17 animais com vaginite.

No Brasil, observaram a presença de $U$. diversum em $38.8 \%$ de vacas apresentando vulvaginite, associando a presença destes microrganimos com disturbios reprodutivos do rebanho brasileiro, revelando a importancia do diagnóstico laboratorial desta espécie (CARDOSO et al., 2000). Buzinhani et al. (2007c) observaram que $U$. diversum foram isolados em $25,0 \%$, das amostras analisadas. Além disto, pela PCR específica, este microrganismo foi detectado $37,5 \%$ das amostras.

Estudo realizado por Leon et al. (1995), indicaram como fatores de risco associados às infecções por ureaplasmas no trato reprodutivo de vacas leiteiras, a idade dos bovinos, número de partos e raça. Vacas mais jovens e 
com menor número de partos possuem maior risco de adquirir a infecção. As infecções ocorrem com maior freqüência no inverno, quando comparadas ao verão, sugerindo a transmissão direta em rebanhos confinados. A transmissão venérea de touros infectados é importante na disseminação da doença, não podendo ser descartada a transmissão indireta, por fômites (DOIG et al., 1981). As vias de eliminação dos micoplasmas e ureaplasmas são secreções orgânicas, especialmente sêmen, mucos prepucial e vaginal, secreção conjuntiva e leite. A principal forma de transmissão é o contágio direto pelo coito, onde touros infectados disseminam por meio da monta natural ou inseminação artificial (BRITTON et al., 1988; KIRKBRIDE, 1987; MILLER et al., 1994). A inseminação artificial está associada a severas diminuições de concepção no primeiro serviço, infecções agudas, sendo a forma crônica menos severa, mas também responsável por infertilidade. A infecção pode ser introduzida no útero através do sêmen infectado ou por infecções préexistentes na vagina carreadas para a cérvix pela pipeta de inseminação (DOIG et al., 1979).

U. diversum está envolvido em casos de vesiculite seminal, balanopostite, epididimite (PILASZEK e TRUSZCYNSKI, 1988) e outras patologias por alterações morfológicas e funcionais nos espermatozóides (EAGLESOME et al., 1992; PANANGALA et al., 1981). Os ureaplasmas colonizam o prepúcio e a porção distal da uretra de touros e raramente foram isolados da ampola e vesícula seminal (FISH et al., 1985). A cavidade prepucial parece ser o principal ponto na contaminação do sêmen em touros quando a coleta é efetuada com vagina artificial. Entretanto, demonstrou-se que a uretra também é altamente colonizada, sugerindo que os procedimentos instituídos para reduzir o número de microrganismos no prepúcio, podem não ser totalmente efetivo na eliminação da contaminação do sêmen (DOIG et al., 1981).

Le Grand et al. (1995) demonstraram a alta freqüência de ureaplasma na cavidade prepucial e sêmen de touros destinados a inseminação artificial. Ball et al. (1987) cultivaram 332 amostras de sêmen fresco e encontraram micoplasmas em $46 \%$ e ureaplasma em $32 \%$. Estes ureaplasmas não foram eliminados pelo tratamento com lincospectina. Ruhnke e Rosendal (1994) reportaram variação de 23 a $84 \%$ de culturas positivas em sêmen fresco de 
touros para $U$. diversum e 29 a $100 \%$ de positivos em amostras de muco prepucial e secreção de uretra distal. Le Grande et al. (1995) isolaram U. diversum em $74 \%$ das amostras de sêmen analisadas, sendo os grupos B e C predominantes. MULIRA et al. (1992) observaram que $47,2 \%$ do touros leiteiros e $67,6 \%$ dos touros de cortes apresentavam $U$. diversum no trato reprodutivo.

A aderência dos microrganismos interfere na espermatogênese, transporte espermático, capacitação e fecundação. Os espermatozóides podem atuar na transmissão dos agentes, pois os antibióticos rotineiramente utilizados em Centrais de Inseminação não eliminam micoplasmas e ureaplasmas (ERA et al., 1995).

$U$. diversum também é capaz de produzir severa placentite e alveolite fetal, que pode resultar em aborto ou nascimento de bezerros fracos. A infecção apresenta-se de forma crônica, onde o microrganismo multiplica-se no concepto por 117 dias e pode ser eliminado pela urina e por descarga vulvar após a expulsão do bezerro (MILLER et al., 1983). Este microrganismo foi associado a aborto e morte de bezerros recém-nascidos por isolamento deste agente no pulmão dos fetos abortados e histopatologia das lesões (RUHNKE et al., 1984).

Alguns trabalhos relatam a patogenicidade no trato respiratório de $U$. diversum pela conseqüência da inoculação experimental em bezerros. Howard et al. (1976) inocularam o agente endobroquialmente e concluíram que a espécie era patogênica para bezerros devido à morte destes animais. Ter Laak et al. (1993), com o mesmo tipo de inoculação, observaram a formação de um agrupamento de células arredondadas ao redor dos brônquios e bronquíolos e o desenvolvimento de pneumonia lobular catarral.

Existem poucos dados na literatura de estudos epidemiológicos de $U$. diversum no trato respiratório de bezerros, o que pode ser explicado pela necessidade do uso de meios específicos para o isolamento desta espécie. No presente estudo, $U$. diversum foi detectado em 12 amostras (8,22\%) coletadas de animais sadios e $49(31,61 \%)$ com distúrbios respiratórios. Ter Laak et al. (1992) estudaram 148 bezerros com pneumonia e detectaram U. diversum em $48 \%$ das amostras. Gagea et al. (2006) determinaram a prevalencia de diversos patógenos associados com mortalidade e morbidade em bezerros de corte, sendo $U$. diversum detectado em $25 \%$ dos animais analisados. 
Muenster et al. (1978) utilizaram fragmentos de pulmão de bezerros com pneumonia e detectaram a presença desta espécie em $44 \%$ dos animais. Os resultados obtidos deste trabalho, no entanto, não concordam com Thomas et al. (2002), onde $U$. diversum não foi detectado em animais sadios, somente em $15,4 \%$ dos animais doentes. Os animais sadios positivos para $M$. dispar e $U$. diversum estavam em contato direto com animais doentes em que foram detectadas estas espécies. Em propriedades onde não havia animais doentes, estas espécies não foram diagnosticadas. No Brasil, Marques et al. (2007) detectaram este microrganismo em $8,22 \%$ das amostras de muco nasal de bezerros sadios e em $31,6 \%$ de amostras coletadas em animais apresentando distúrbios respiratórios. 


\section{OBJETIVOS}

\subsection{Objetivos Gerais}

- Avaliar a variabilidade genética e fatores de virulência em cepas e isolados de $U$. diversum.

\subsection{Objetivos específicos}

- Avaliar a variabilidade genética nos genes $16 \mathrm{~S}$ rRNA e urease de $U$. divesum isolados de material clínico;

- Verificar a presença de cápsula dos ureaplasmas isolados de material clínico;

- Examinar a atividade de fosfolipase C dos ureaplasmas isolados de material clínico;

- Verificar a atividade de IgA protease nos ureaplasmas isolados de material clínico;

- Avaliar a adesão e invasão em células Hep-2 dos ureaplasmas isolados de material clínico. 


\section{MATERIAL E MÉTODOS}

\subsection{Cepas de ureaplasmas}

Neste estudo incluíram-se as cepas de U. diversum ATCC sorogrupo A (49782), sorogrupo C (49783) e 34 isolados de campo, sendo 24 obtidos de fêmeas com distúrbios reprodutivos e 10 isolados de sêmen bovino. Os isolados de fêmeas foram obtidos de muco vulvovaginal de fêmeas provenientes de sete propriedades tecnificadas, sendo quatro no Estado de São Paulo (P1: cepas A203, 64 e 59; P2: ALVA, GOTA, 98, 91, 95, 93, 94, 100 e 102; P4: 77, 84, 72, 73 e 74; P7: 19V, 16V, 7V e 9V), uma no Mato Grosso do Sul (P3: 1664 e 805) uma em Minas Gerais (P6: Ud11, Ud18 e Ud3) e uma em Alagoas (P5: 112). As coletas das amostras de muco vulvovaginal foram realizadas no período de 1999 a 2005. Os isolados de amostras de sêmen foram obtidos diretamente da semeadura de sêmen envasado em palhetas, adicionados antibióticos, de cinco centrais de inseminações no Estado de São Paulo (cepas S1, S6, S7, S8, 12T, 13T, 15T, 16T, 10T e 7T). Para o controle de alguns testes incluiu-se a cepa T-960 de U. urealyticum (correspondente ao sorotipo 7) de origem humana.

\subsection{Meio de Cultura}

Os meios líquidos e sólidos Ureaplasma (RUHNKE, 1994), acrescido de CRML®, foram utilizados no cultivo das cepas e estirpes de $U$. diversum. $\mathrm{Na}$ avaliação das características morfológicas das colônias utilizou-se o meio sólido contendo 1\% de ágar (RUHNKE, 1994).

\subsubsection{Meio Ureaplasma Líquido - UB (100 mL)}

PPLO $\left(\right.$ Merck $\left.^{(}\right)$

Água deionizada $63,0 \mathrm{~mL}$

pH em 6,0 
Autoclavar a $121^{\circ} \mathrm{C}$ por 20 minutos (min);

Acrescentar assepticamente ao meio autoclavado:

Soro eqüino (Cultilab)

$20 \mathrm{~mL}$

Extrato fresco de levedura $25 \%$

$10 \mathrm{~mL}$

Penicilina $100000 \mathrm{U} / \mathrm{mL}\left(\right.$ Sigma $\left.^{(\circledast)}\right)$

$0,5 \mathrm{~mL}$

CRML 1066 (Invitrogen ${ }^{(\Theta)}$

$5,0 \mathrm{~mL}$

Uréia 10\% $\left(\right.$ Sigma $^{(\Theta)}$

$1,0 \mathrm{~mL}$

L-cisteína 2\% $\left(\right.$ Merck $\left.^{(\circledR)}\right)$

$0,1 \mathrm{~mL}$

Vermelho de fenol 0,5\% $\left(\right.$ Merck $\left.^{\circledR}\right)$

$0,4 \mathrm{~mL}$

Realização do teste de esterilidade a $37^{\circ} \mathrm{C}$, por 24 horas.

\subsubsection{Meio Ureaplasma Sólido - UB (100 mL)}

TSB $\left(\right.$ Merck $^{(\Theta)}$

Água deionizada

Ágar Noble (Invitrogen ${ }^{(\boxplus)}$
$2,1 \mathrm{~g}$ $60,0 \mathrm{~mL}$

$1,0 \mathrm{~g}$

$\mathrm{pH}$ em 6,0

Autoclavar a $121^{\circ} \mathrm{C}$ por 20 minutos (min);

Acrescentar assepticamente ao meio autoclavado:

Soro eqüino (Cultilab)

$20 \mathrm{~mL}$

Extrato fresco de levedura $25 \%$

$10 \mathrm{~mL}$

Penicilina 100000 U/mL (Sigma $\left.{ }^{(}\right)$

$0,5 \mathrm{~mL}$

CRML 1066 (Invitrogen ${ }^{(\mathbb{\theta})}$ )

$5,0 \mathrm{~mL}$

Uréia $10 \%\left(\right.$ Sigma $\left.^{\circledR}\right)$

$1,0 \mathrm{~mL}$

Sulfato de manganês 3\% $\left(\right.$ Merck $\left.^{\circledR}\right)$

$0,5 \mathrm{~mL}$

Vermelho de fenol 0,5\% $\left(\right.$ Merck $\left.^{\circledR}\right)$

$0,4 \mathrm{~mL}$

Realização do teste de esterilidade a $37^{\circ} \mathrm{C}$, por 24 horas.

\subsection{Subcultivo das cepas e estirpes de U. diversum}

Os microrganismos, previamente estocados a $\quad-70 \quad{ }^{\circ} \mathrm{C}$, foram descongelados e subcultivados em meio líquido UB. Inoculou-se $200 \mu \mathrm{l}$ de 
cada cultura estoque em $1,8 \mathrm{~mL}$ de meio líquido e incubou-se a $37{ }^{\circ} \mathrm{C}$. $\mathrm{O}$ crescimento foi observado com a mudança de cor do meio, pela alcalinização do $\mathrm{pH}$ (vermelho de fenol), resultante da hidrólise da uréia. No meio sólido, observou-se a formação de pequenas colônias granulosas de coloração marrom escuro, resultante da precipitação de cátions de manganês pela atividade da urease (RUHNKE, 1994). Volumes de 2 a $200 \mathrm{~mL}$, das culturas de ureaplasma, foram usados nos testes de fatores de virulência e na obtenção dos DNAs utilizados nas metodologias moleculares.

\subsection{Sequênciamento dos nucleotídeos}

As cepas e os isolados de $U$. diversum foram submetidas a PCR para os genes 16S rRNA e urease e os produtos sequenciados para a análise da variabilidade genética.

\subsubsection{Subcultivo das amostras destinadas ao seqüenciamento}

Realizou-se o subcultivo, em $2 \mathrm{~mL}$ de meio UB, das cepas de $U$. diversum (ATCC 49782 e 49783), de 24 isolados de obtidos de muco vulvovaginal e dez, de sêmen bovinos.

\subsubsection{Extração do DNA}

A extração de DNA dos isolados e das cepas de $U$. diversum foi realizada pelo método de extração descrito por Boom et al. (1990), com algumas modificações. Foi transferido a um microtubo, $700 \mu \mathrm{l}$ da amostra (cultura dos isolado e cepas), $1,0 \mathrm{~mL}$ do tampão de lise e $40 \mu \mathrm{l}$ de suspensão de sílica, homogeneizado em agitador (30 s) e mantido em repouso por 10 minutos (min). Em seguida, esta solução foi centrifugada a $14175 \mathrm{~g}$ por $3 \mathrm{~min}$, removendo-se o sobrenadante. O sedimento foi homogeneizado com $0,5 \mathrm{~mL}$ de tampão de lavagem e centrifugado a $14175 \mathrm{~g}$ por $3 \mathrm{~min}$, por duas vezes. Adicionou-se a este sedimento $500 \mu \mathrm{l}$ etanol (70\%), que foi homogeneizado e centrifugado, como anteriormente. Após o tratamento com etanol, o sedimento foi homogeneizado em $500 \mu \mathrm{l}$ de acetona, centrifugado e lavado duas vezes 
como tampão de lavagem e mantido em estufa a $37{ }^{\circ} \mathrm{C}$ por 20 min até total desidratação. O sedimento foi homogeneizado com $150 \mu \mathrm{l}$ de água ultrapura, por 60 segundos (s), e mantidos a $56{ }^{\circ} \mathrm{C}$ por $10 \mathrm{~min}$. Em seguida, a solução foi homogeneizada por $60 \mathrm{~s}$ e concentrada a $14175 \mathrm{~g}$ por $10 \mathrm{~min}$. O sobrenadante final de $150 \mu$ l, contendo o DNA bacteriano, foi retirado e armazenado a $-20{ }^{\circ} \mathrm{C}$.

\subsubsection{PCR para amplificação do gene 16S rRNA}

Os "primers" F16S e R16S (Quadro 1) utilizados foram descritos por Harasawa et al. (1996) e amplificam a seqüência 16S rRNA da Classe Mollicutes.

Quadro 1. "Primers" para a detecção do gene 16S rRNA.

\begin{tabular}{|ccc|}
\hline Iniciadores & \multicolumn{1}{c|}{ Seqüência } & Produto \\
\hline F16S & 5'- GAG TTT GAT CCT GGC TCA GG-3' & \\
R16S & 5'- GGG ATA CCT TGT TAC GAC TT-3' & 1400 pb \\
\hline
\end{tabular}

Para a reação em cadeia da polimerase foi adicionado a um microtubo $(0,2 \mathrm{~mL}): 10 \mu \mathrm{l}$ de tampão para a PCR $(\mathrm{KCl} 500 \mathrm{mM}$, Tris $200 \mathrm{mM}$ em pH 8,4), 10 pmol de cada "primer", 0,5 U de Taq DNA polimerase High Fidelity (Platinum-Invitrogen ${ }^{\circledR}$ ), 1,5 mM de $\mathrm{MgCl}_{2}, 200 \mathrm{mM}$ de deoxiribonucleotídeos trifosfato (dNTP), $5 \mu \mathrm{L}$ da amostra de DNA e água ultrapura até o volume final de $50 \mu \mathrm{L}$. A amplificação foi realizada em termociclador programado para: um ciclo de $94{ }^{\circ} \mathrm{C}$ por 5 min, 30 ciclos de $95{ }^{\circ} \mathrm{C}$ por $30 \mathrm{~s}, 58{ }^{\circ} \mathrm{C}$ por $30 \mathrm{~s}, 72{ }^{\circ} \mathrm{C}$ por $1 \mathrm{~min}$, um ciclo final de $72{ }^{\circ} \mathrm{C}$ por 5 min e $4{ }^{\circ} \mathrm{C}$ por $10 \mathrm{~min}$. Após a amplificação, as amostras foram mantidas a $4 \stackrel{\circ}{\circ}$, até o momento da eletroforese. 


\subsubsection{PCR para amplificação do gene da urease}

Para a amplificação do gene da urease, foram utilizados os "primers" (Quadro 2), que compreende a região $\mathrm{C}$-terminal da subunidade $\beta$, uma região intergênica e a região $\mathrm{N}$-terminal da subunidade $\alpha$ do gene da urease (KNOX et al., 1998).

Quadro 2. "Primers" para a detecção do gene da urease.

\begin{tabular}{|lcc|}
\hline Iniciadores & \multicolumn{1}{c}{ Seqüência } & Amplicon \\
\hline $14 \mathrm{~b}$ & $5^{\prime}$-CCAGGTAAATTAGTACCAGG- 3' & $458 \mathrm{pb}$ \\
$72 \mathrm{c}$ & $5^{\prime}$-CCTAATCTAACGCTATCACC-3' & \\
\hline
\end{tabular}

A reação foi preparada em volumes de $100 \mu$ contendo: $10 \mu$ de tampão para a PCR $(\mathrm{KCl} 500 \mathrm{mM}$, Tris $200 \mathrm{mM}$ em pH 8,4); $200 \mathrm{mM}$ de dNTP; $2,5 \mathrm{mM}$ de $\mathrm{MgCl}_{2} ; 25$ pmol de cada "primer"; $2 \mu \mathrm{l}$ de amostra de DNA e 2 unidade de Taq DNA polimerase High Fidelity (Platinum-Invitrogen ${ }^{\circledR}$ ). A amplificação do gene da urease foi estabelecida em: 1 ciclo de 5 min, a $94{ }^{\circ} \mathrm{C}, 35$ ciclos de 30 $\mathrm{s}$, a $94{ }^{\circ} \mathrm{C}, 1 \mathrm{~min}$ a $55^{\circ} \mathrm{C}$ e 1 min a $72{ }^{\circ} \mathrm{C}$ e, logo após, 1 ciclo de $10 \mathrm{~min}$ a 72 ${ }^{\circ} \mathrm{C}$. Após a amplificação, as amostras foram mantidas a $4 \stackrel{\circ}{\circ} \mathrm{C}$, até o momento da eletroforese.

\subsubsection{Detecção do produto amplificado}

Os produtos da PCR $(10 \mu \mathrm{l})$ e o marcador 100 pb DNA Ladder $\left(\right.$ Invitrogen ${ }^{\circledR}$ ) foram separados por eletroforese em gel de agarose a $1 \%$, contendo $10 \mu \mathrm{g} / \mathrm{mL}$ de brometo de etídeo, em tampão TAE (40 mM Trisacetato; 2 mM EDTA, pH 8,0). A visualização dos produtos foi sob luz UV. 


\subsubsection{Purificação e quantificação do DNA para seqüenciamento}

Os produtos da PCR do gene 16S rRNA e gene da urease foram analisados em eletroforese em gel de agarose para confirmar a presença de apenas um fragmento. O produto foi purificado utilizando o GFX PCR DNA and Gel Band Purification Kit (Amersham ${ }^{\circledR}$ ) e quantificado em gel de agarose 2\% utilizando o Low DNA Mass Ladder (Invitrogen ${ }^{\circledR}$ ).

\subsubsection{Sequenciamento}

As amostras amplificadas e purificadas foram enviadas ao Instituto de Ciências Biomédicas (ICB-USP), Laboratório de Reparo de DNA. As reações de seqüenciamento foram realizadas de acordo com o protocolo para 0 MegaBACE 1000, utilizando o DYEnamic ET Dye Terminator Kit (com Thermo Sequenase $^{\mathrm{TM}}$ II DNA Polimerase) código US81090. As sequências foram analisadas pelo software Sequence Analyser utilizando o Base Caller Cimarron 3.12.

\subsubsection{Alinhamento e construção de árvore de similaridade}

As sequências obtidas foram analisadas e comparadas à publicada no GenBank, por meio da verificação de similaridades pelo programa BLAST (BENSON et al., 2002). As análises foram realizadas utilizando o Programa MEGA-4 ("Phylogenetic and molecular evolutionary analyses - MEGA version 4.1") (TAMURA et al., 2007). O alinhamento dos nucleotídeos foi realizado pelo método Clustal-W (THOMPSON et al., 1997) com deleção dos gaps. As seqüências alinhadas foram reamostradas com "bootstrap" de 1.000 e as árvores foram construídas pelo método de "neighbor-joining", com matriz de distância Tajima-Nei. 


\subsection{Avaliação dos fatores de virulência de Ureaplasma diversum}

Os isolados e cepas de $U$. diversum foram avaliados quanto a presença de cápsula, atividade de fosfolipase $C$, atividade de $\lg A$ protease e adesão e invasão em células Hep-2.

\subsubsection{Presença de cápsula}

Para este estudo, foram utilizadas as cepas de referência de $U$. diversum e sete isolados, sendo cinco de muco vulvovaginal de fêmeas bovinas $(77,64$, Ud11, A203 e Alva) e dois de sêmen bovino (10T e S8). A presença de cápsula nas espécies de ureaplasma foi determinada por microscopia eletrônica de transmissão, como descrita por Almeida e Rosenbusch (1991), com modificações. Os isolados foram primeiramente cultivados em $50 \mathrm{~mL}$ de meio UB. Os ureaplasmas foram sedimentados por centrifugação a $20.600 \mathrm{~g}$ por 30 min, sendo o sedimento homogeneizado em tampão cacodilato 0,01 M com 3\% de glutaraldeído e $0.2 \%$ de vermelho de ruteno $(\mathrm{pH} \mathrm{7,4)}$. Os microrganismos foram lavados cinco vezes com tampão cacodilato $0.05 \mathrm{M}$, fixados com $1 \%$ de tetróxido de ósmio, desidratados com gradiente de etanol e tratado com resina Spurr (Electron Microscopy Sciences, Fort Washington, USA). Os cortes ultrafinos foram analisados em Microscópio Eletrônico de Transmissão JEOL 1010.

\subsubsection{Atividade de fosfolipase C}

Nesta avaliação, foram utilizados os 34 isolados e as cepas de $U$. diversum e uma cepa de referência de U. urealyticum (T960). Para o teste qualitativo de fosfolipase, o composto cromogênico p-nitrofenilfosforilcolina $\left(\right.$ Sigma $\left.^{\circledR}\right)$, um análogo de fosfatidilcolina, foi usado como substrato, como descrito por Silva e Quinn (1987). A hidrólise deste composto libera fosforilcolina e p-nitrofenol (cromógeno amarelo). Para a visualização da 
atividade fosfolipase, o ágar UB foi suplementado com $20 \mathrm{mM}$ de $\mathrm{p}$ nitrofenilfosforilcolina (pNPPC). As espécies de ureaplasma $(50 \mu \mathrm{l})$ foram plaqueadas uniformemente na superfície do ágar e incubadas em aerofilia a 37 ${ }^{\circ} \mathrm{C}$ por $24 \mathrm{~h}$. Como controles negativos foram semeadas bactérias em meio UB sem a adição do p-nitrofenilfosforilcolina e meio UB com adição de pNPPC, mas sem a inoculação de ureaplasma.

Para o teste quantitativo, foi utilizado caldo UB suplementado com $20 \mathrm{mM}$ de pNPPC. A análise foi realizada em microplaca com 96 orifícios (TPP Switzerland). As cepas e isolados foram inicialmente cultivadas em $1 \mathrm{~mL}$ de caldo UB suplementado com pNPPC por $24 \mathrm{~h}$ a $37^{\circ} \mathrm{C}$. As amostras foram centrifugadas a $20.600 \mathrm{~g}$ por $30 \mathrm{~min}$. e o sobrenadante foi transferido para as microplacas e avaliado em espectrocolorímetro (Multiskan Microplate Reader, Flow Laboratories, Canadá) com comprimento de onda de $405 \mathrm{~nm}\left(\mathrm{OD}_{405}\right)$. A hidrólise do PNPPC foi determinada, em triplicata, por meio da diferença dos valores obtidos das cepas e isolados e do controle negativo com meio UB suplementado com pNPPC, sem cultura bacteriana.

\subsubsection{Atividade de IgA protease}

Neste estudo, foram utilizadas 34 isolados, as cepas ATCC de $U$. diversum e uma cepa de referência de $U$. urealyticum (T960). Para o teste de IgAse foi utilizado o procedimento descrito por Kapatais-Zoumbos et al. (1985), com modificações. Dez mililitros da cultura bacteriana foram concentrados em $50 \mu \mathrm{l}$ de PBS por centrifugação a $14714 \mathrm{~g}$. Este volume foi incubado com $10 \mu \mathrm{l}$ de slgA bovina ( $10 \mathrm{mg} / \mathrm{ml}$ - InterCell Tecnologies $\left.{ }^{\circledR}\right)$ a $37{ }^{\circ} \mathrm{C}$ por 18 horas (h.). As suspensões foram centrifugadas a $14714 \mathrm{~g}$ por $10 \mathrm{~min}$., sendo o sobrenadante armazenado a $-20 \stackrel{\circ}{ } \mathrm{C}$ até 0 momento da análise. Nos sobrenadantes foram adicionados $\beta$-mercaptoetanol e Loading Buffer (Tris 0,5 M; SDS 10\%; $\beta$ mercaptoetanol; Bromofenol Blue), e foram submetidos a fervura por $5 \mathrm{~min}$. As amostras foram submetidas à eletroforese em gel SDS-PAGE (12\% de poliacrilamida) com Running Buffer (Tris $250 \mathrm{mM} ; 2 \mathrm{M}$ Glicina; 1\% SDS). As proteínas do gel foram reveladas usando o método de nitrato de prata (TUÑON e JOHANSON, 1984). O peso molecular dos fragmentos de imunoglobulinas 
foram obtidos por meio do marcador Low molecular weight calibration kit for SDS eletrophoresis com fragmentos variando entre 14.4 a $97 \mathrm{KDa}$ (GE Healthcare $\left.{ }^{\circledast}\right)$. Na eletroforese foram adicionados a cepa ou isolado analisado sem a incubação com a slgA e a slgA $\left(10 \mathrm{mg} / \mathrm{ml}\right.$ - InterCell Tecnologies $\left.{ }^{\circledR}\right)$, como controles. A análise dos resultados foi realizada pela comparação dos perfis proteícos obtidos da cepa incubada com a slgA comparado com os perfis dos controles, para verificar a presença ou ausência de bandas resultantes da atividade da enzima.

\subsubsection{Adesão e invasão}

As cepas e isolados de $U$. diversum selecionados foram inoculados em células Hep-2 para a análise em microscópio confocal e confirmação de internalização por meio do teste da gentamicina.

\subsubsection{U. diversum e células Hep-2}

Foram estudados quatro isolados de $U$. diversum e as cepas de referência, ATCC 49782 e 49783. Os isolados 77 e A203 foram obtidos de muco vaginal de vacas apresentando vulvovaginite (alta passagem) e os isolados 10T e S8 foram obtidos de sêmen bovino (baixa passagem).

A linhagem celular Hep-2 (ATCC-USA CCL-23), utilizada no estudo de invasão, foi previamente testada, quanto à ausência de micoplasmas, por cultura e PCR (VAN KUPPEVELD et al., 1992). As células foram cultivadas em meio MEM (Minimum Essential Medium) com 2 mM L-glutamina, solução de Earl's e 10\% de soro fetal bovino (Cult Lab, São Paulo, Brazil) em 5\% $\mathrm{CO}_{2}$ a 37 ${ }^{\circ} \mathrm{C}$. As células foram re-cultivadas, $24 \mathrm{~h}$ antes da infecção, em confluência de 10-20\% em placas de poliestireno com 24 orifícios (TPP - Suíça), contendo lamínulas de vidro de $13 \mathrm{~mm}$ (Glasstécnica - Brasil), com $1 \mathrm{~mL}$ de MEM para análise na microscopia confocal. 


\subsubsection{Marcação e quantificação dos ureaplasmas}

O método utilizado foi descrito por Basemam et al. (1995), com modificações. Os ureaplasmas foram primeiramente cultivados em $50 \mathrm{~mL}$ de meio $U B$ a $37 \stackrel{\circ}{\circ}$. As bactérias foram centrifugadas a $20.600 \mathrm{~g}$ por $30 \mathrm{~min}$ e o sedimento foi lavado duas vezes com PBS. No sedimento foram adicionados $200 \mu \mathrm{l}$ de carbocyanine dye solution (Vybrant ${ }^{\mathrm{TM}}$ Dil cell-labeling solution-Dil, V22885, Molecular Probe, Eugene, Oregon, USA - diluição 1:200) e incubado a $37 \stackrel{\circ}{\circ}$ por $40 \mathrm{~min}$. A quantificação do inóculo bacteriano $\left(10^{5}\right.$ a $10^{7}$ ureaplasma/mL) foi realizada por diluição decimal (1:10) para a determinação da Unidade de Mudança Colorimétrica ("Color Change Unit" - CCU) (TAYLORROBINSON, 1983). Os ureaplasmas marcados foram centrifugados a $20.600 \mathrm{~g}$ por 10 min, lavados duas vezes com PBS e homogeneizados para a inoculação nas monocamadas de células Hep-2.

\subsubsection{Inoculação dos ureaplasmas em células Hep-2 (BASEMAN et al., 1995)}

As culturas de células Hep-2 com 60 a $70 \%$ de confluência, com aproximadamente $10^{6}$ células/lamínula, foram selecionadas para a infecção com ureaplasmas marcados. As células foram inicialmente lavadas com PBS e inoculadas com $10^{5}$ a $10^{7}$ ureaplasmas marcados homogeneizados em $1 \mathrm{~mL}$ de MEM com $2 \%$ de soro fetal bovino. As células inoculadas foram incubadas a 37 - $\mathrm{C}$ com $5 \%$ de $\mathrm{CO}_{2}$ e avaliadas após primeiro minuto de infecção, aos $30 \mathrm{~min}$, 3, 8 e $12 \mathrm{~h}$. A cada período avaliado, o inóculo bacteriano foi removido e as células foram lavadas três vezes com PBS. As células foram fixadas com 3,7\% de formaldeído por $30 \mathrm{~min}$ em temperatura ambiente, lavadas por três vezes com PBS e incubadas com $0.05 \%$ de Triton X-100 por 10 min. 


\subsubsection{Marcação das células Hep-2}

Para a visualização do citoesqueleto de células infectadas e não infectadas, estas foram incubadas por $30 \mathrm{~min}$ a $37^{\circ} \mathrm{C}$ com faloidina associada ao isotiocianato de fluoresceína (FITC, Sigma ${ }^{\circledR}$ ) diluído a 1:200. O fluorocromo foi removido por meio de três lavagens com PBS e as células foram tratadas com RNase (10 mg/mL) por 30 min. O núcleo foi marcado com TO-PRO-3 (Molecular Probes ${ }^{\circledast}$, diluição 1:500). As lamínulas com as células Hep-2 infectadas e marcadas foram montadas com Vecta Shield (Vecta Shield, Vector Laboratories, Burlingame, CA, USA) em lâminas histológicas.

\subsubsection{Verificação de invasão nuclear}

A células Hep-2 foram infectadas e fixadas com 3.7\% de formaldeído, tratadas com $0.5 \%$ Triton X-100 e a delimitação da invasão do núcleo pelos ureaplasmas foram realizadas por meio da incubação com anticorpo primário anti-B lamina $\left(1: 100\right.$, Sigma $\left.^{\circledR}\right)$ por $18 \mathrm{~h}$. Em seguida, as células foram lavadas três vezes com PBS e incubadas por $3 \mathrm{~h}$ com anticorpo secundário "anti-goat" conjugado com fluoresceína $\left(\right.$ FITC, Sigma $\left.{ }^{\circledR}\right)$. As células foram lavadas três vezes com PBS e as lâminas histológicas foram montadas com Vecta Shield. A lamina nuclear é uma proteína supramolecular associada à superfície da membrana nucleoplasmática, localizada no interior da membrana nuclear.

\subsubsection{Microscopia Confocal}

Células Hep-2 infectadas e não infectadas foram observadas em Microscópio Confocal (Carl Zeiss LSM 510, Germany), equipado com laser Argônio, $488 \mathrm{~nm}$, e dois hélio/neônio $543 \mathrm{~nm}$ de comprimentos de onda para diferenciar a luminescência dos fluorocromos. Aproximadamente vinte campos, com 8 a 10 células infectadas ou não com ureaplasma, foram examinados nos períodos de estudo da infecção. Cortes ópticos, variando da região basal à 
apical da célula, incluindo secções do plano nuclear e imagens tri-dimensionais da distribuição intracelular dos microrganismos marcados, foram obtidos e documentados.

\subsubsection{Teste da Gentamicina}

O teste da gentamicina, descrito por Yavlovich et al. (2004a), foi realizado para a determinação da taxa de invasão dos ureaplasmas. As células Hep-2 foram cultivadas em placas de poliestireno com 24 orifícios ( $10^{4}$ células por orifício). Após $24 \mathrm{~h}$ de incubação ( $5 \% \mathrm{CO}_{2}$ e $\left.37^{\circ} \mathrm{\circ}\right)$, as células foram infectadas com $10^{5}$ a $10^{7}$ ureaplasmas $(\mathrm{CCU} / \mathrm{mL})$ e incubadas por três horas. Em seguida, as células foram lavadas três vezes com PBS e incubadas por três horas em meio MEM ( $1 \mathrm{~mL} /$ orifício), contendo $400 \mu \mathrm{g} / \mathrm{mL}$ de gentamicina, para eliminar os ureaplasmas que não internalizaram nas células. $O$ antibiótico foi removido e as células infectadas foram tripsinizadas e cultivadas em meio UB para a determinação da CCU. A taxa de infecção foi calculada comparando-se o número de microrganismos estimado em $\mathrm{CCU} / \mathrm{mL}$ no inóculo inicial do teste de infecção com o $\mathrm{CCU} / \mathrm{mL}$ obtido após tratamento com a gentamicina. Todos os testes foram realizados em triplicata. 


\section{RESULTADOS}

\subsection{Subcultivo das cepas e isolados de $U$. diversum}

As cepas e isolados de $U$. diversum, estocadas a $-70^{\circ} \mathrm{C}$, apresentaram tempos de crescimento diferenciados de 10 a $48 \mathrm{~h}$ de incubação, que foram acompanhadas pela visualização da mudança de cor do meio. Todas as amostras confirmaram crescimento em ágar, pela produção de colônias marrom escuras de aspecto granuloso.

\subsection{Variabilidade no gene 16S rRNA}

\subsubsection{PCR do gene 16S rRNA}

Todas as amostras amplificadas com os "primers" universais para o gene 16S rRNA resultaram em um produto de aproximadamente 1500 pb (Figura 3). No sequenciamento deste produto foram obtidos dois fragmentos com aproximadamente $650 \mathrm{pb}$.

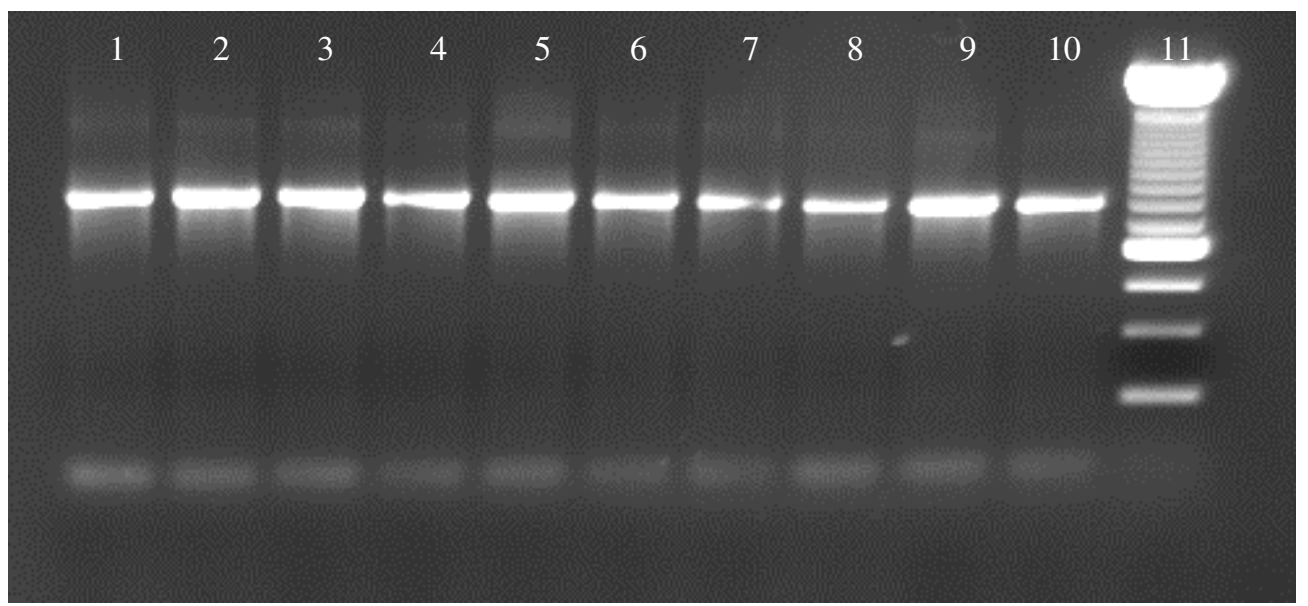

Figura 3. Eletroforese em gel de agarose dos produtos da PCR utilizando "primers" F16S e R16S a partir do DNA de U. diversum. Linhas 1 a 10: isolados de U. diversum. Linha 11: padrão de peso molecular - $1 \mathrm{Kpb}$ 


\subsubsection{Análise intra-específica do gene 16S rRNA}

A seqüência completa do gene $16 \mathrm{~S}$ rRNA do $U$. diversum, disponível no Genbank (HARASAWA e CASSELL, 1996) número de acesso D78650, foi utilizada para a comparação das seqüências obtidas no presente estudo. As abreviações A, C, G e T referem-se, respectivamente, aos nucleotídeos Adenina, Citosina, Guanina e Timina. Os polimorfismos foram nomeados pela sua posição em relação ao gene $16 \mathrm{~S}$ rRNA, indicados no código da União Internacional de Bioquímica (IUBMB) como: $Y=T / C ; R=A / G ; M=A / C ; K=$ $\mathrm{G} / \mathrm{T} ; \mathrm{W}=\mathrm{A} / \mathrm{T}$ e $\mathrm{S}=\mathrm{G} / \mathrm{C}$.

A análise do sequênciamento parcial do gene 16S rRNA de aproximadamente $595 \mathrm{pb}$ das duas cepas de referência e 34 isolados de $U$. diversum. Este fragmento esta presente entre as posições 99 a 694 do gene $16 \mathrm{~S}$ rRNA de $U$. diversum, e abrange em quatro regiões de variabilidade, como descrito por Harasawa e Cassell (1996). Esta análise resultou na presença de polimorfismos em 44 posições da seqüência (Tabela 1) e presença de deleções e inserções apenas no isolado 112.

Alteração nas posições 160 e 238 do tipo $M$ foram observadas em todos os isolados quando comparados as cepas de referência sequenciadas neste estudo e à sequência depositada no GenBank. Foi observado polimorfismos nas posições 295, 298, 406, 448, 459, 515 e 534 em grande parte dos isolados estudados.

Alguns polimorfismos foram observados nos isolados pertencentes as mesmas propriedades, como a presença nas posições 133, 212 e 213, que foram restritos aos isolados da propriedade Touro 2. Nas propriedades Touro 2, P6 e P7 observou-se que os isolados, de cada propriedade, apresentavam perfis idênticos. Os isolados da P1 e P3 apresentaram padrões polimórficos distintos, quando comparados entre si. As propriedades P2, P4, P5 e Touro 1 apresentavam menores números de polimorfismos quando comparados aos isolados da $\mathrm{P} 1$ e $\mathrm{P} 3$.

Os polimorfismos $W$ e $R$ foram os mais presentes nas posições analisadas (11 posições cada), seguidos do $Y$ (10 posições), $S$ e $K$ (9 posições). O polimorfismo menos frequente foi o $\mathrm{M}$, presente em apenas quatro posições. 
A matriz de distância entre as amostras dos ureaplasmas pode ser observada na figura 4, onde a distância média entre as cepas e isolados foi de 0,0966 e a observada no isolado 112 foi de 0,2280.

As cepas e os isolado de $U$. diversum apresentaram similaridade mínima de $96 \%$, com exceção do isolado 112 (Figura 5). Como ponto de corte para a definição dos "cluster" na análise intra-específica, utilizou-se a distância de 0,03, o que representa uma similaridade mínima de $97 \%$ entre os isolados. $O$ dendrograma obtido formou sete "cluster": A a G. O "cluster" A foi composto por 18 isolados provenientes de quatro propriedades, sendo duas do Estado de São Paulo (P2 e P7), uma do Mato Grosso do Sul (P3) e uma de Minas Gerais (P6). O "cluster" B foi formado pelo isolado A203 (P1) e o C, composto pelos isolados de sêmen de palhetas (Touro 2).

As cepas de referência $U$. diversum ATCC 48782, ATCC 49783, seqüenciadas, e a sequência de $U$. diversum depositada no GenBank foram agrupadas no "cluster" D. O "cluster" E corresponde aos isolados obtidos nas propriedades do Estado de São Paulo (P1 e P4) e o F, aos de sêmen de palhetas, denominado grupo Touro 1. O "cluster" $G$ foi composto pelo isolado 112 obtido do Estado do Alagoas (P5) e apresentou uma distância aproximada $12 \%$. 
Tabela 1 . Polimorfismos entre as seqüências parciais do gene 16S rRNA de cepas e isolados de $U$. diversum e sequencia depositada no GenBank

\begin{tabular}{|c|c|c|c|c|c|c|c|c|c|c|c|c|c|c|c|c|c|c|c|c|c|c|c|c|c|}
\hline \multirow{2}{*}{ Cepa } & \multicolumn{25}{|c|}{ Posição } \\
\hline & 118 & 119 & 133 & 134 & 159 & 160 & 162 & 171 & 177 & 196 & 197 & 212 & 213 & 238 & 249 & 253 & 255 & 284 & 285 & 295 & 298 & 299 & 300 & 314 & 345 \\
\hline GenBank & $G$ & $G$ & $\mathrm{~T}$ & $A$ & $C$ & $A$ & $G$ & $C$ & $\mathrm{~T}$ & $G$ & $G$ & $A$ & $G$ & $A$ & $C$ & $A$ & $\mathrm{~T}$ & $A$ & $G$ & $A$ & $C$ & $\mathrm{~T}$ & $\mathrm{C}$ & $A$ & $\mathrm{C}$ \\
\hline $5 \mathrm{~T}$ & - & - & W & $\mathrm{R}$ & - & $M$ & - & - & - & - & - & $\mathrm{R}$ & $\mathrm{K}$ & $M$ & - & - & - & $\mathrm{R}$ & $\mathrm{R}$ & - & $\mathrm{Y}$ & $\mathrm{Y}$ & $\mathrm{Y}$ & - & - \\
\hline $7 \mathrm{~T}$ & - & - & W & $\mathrm{R}$ & - & $M$ & - & - & - & - & - & $\mathrm{R}$ & $\mathrm{K}$ & $M$ & - & - & - & $\mathrm{R}$ & $\mathrm{R}$ & - & $\mathrm{Y}$ & $\mathrm{Y}$ & $\mathrm{Y}$ & - & - \\
\hline $7 \mathrm{~V}$ & - & - & - & - & - & $M$ & - & - & - & - & - & - & - & $M$ & - & - & - & - & - & W & $\mathrm{Y}$ & - & - & - & $\mathrm{Y}$ \\
\hline $9 \mathrm{~V}$ & - & - & - & - & - & M & - & - & - & - & - & - & - & M & - & - & - & - & - & W & $\mathrm{Y}$ & - & - & - & $\mathrm{Y}$ \\
\hline 10T & - & - & W & $\mathrm{R}$ & - & $M$ & - & - & - & - & - & $\mathrm{R}$ & $\mathrm{K}$ & $M$ & - & - & - & $\mathrm{R}$ & $\mathrm{R}$ & - & Y & $Y$ & Y & - & - \\
\hline 13T & - & - & W & $\mathrm{R}$ & - & $M$ & - & - & - & - & - & $\mathrm{R}$ & $\mathrm{K}$ & $M$ & - & - & - & $\mathrm{R}$ & $\mathrm{R}$ & - & $\mathrm{Y}$ & Y & $\mathrm{Y}$ & - & - \\
\hline 15T & - & - & W & $\mathrm{R}$ & - & $M$ & - & - & - & - & - & $R$ & $\mathrm{~K}$ & $M$ & - & - & - & $R$ & $R$ & - & $Y$ & - & - & - & - \\
\hline $16 \mathrm{~V}$ & - & - & - & - & - & $M$ & - & - & - & - & - & - & - & $M$ & - & - & - & - & - & W & $Y$ & $Y$ & $Y$ & - & $Y$ \\
\hline $18 \mathrm{~T}$ & - & - & W & $R$ & - & $M$ & - & - & - & - & - & $\mathrm{R}$ & $\mathrm{K}$ & $M$ & - & - & - & $R$ & $R$ & - & $\mathrm{Y}$ & - & - & - & - \\
\hline $19 \mathrm{~V}$ & - & - & - & - & - & $M$ & - & - & - & - & - & - & - & $M$ & - & - & - & - & - & W & $Y$ & - & - & - & $Y$ \\
\hline 59 & - & - & - & - & - & W & - & - & - & - & - & - & - & W & - & - & - & - & - & - & $Y$ & - & - & - & - \\
\hline 64 & - & - & - & - & - & W & - & - & - & - & - & - & - & W & - & - & - & - & - & - & $Y$ & - & - & - & - \\
\hline 72 & - & - & - & - & - & $M$ & - & - & - & - & - & - & - & $M$ & - & - & - & - & - & - & $Y$ & - & - & - & - \\
\hline 73 & - & - & - & - & - & $M$ & - & - & - & - & - & - & - & $M$ & - & - & - & - & - & - & $Y$ & - & - & - & - \\
\hline 74 & - & - & - & $\mathrm{R}$ & - & $M$ & - & - & $Y$ & - & - & - & - & $M$ & - & - & $Y$ & - & - & - & $Y$ & - & - & - & - \\
\hline 77 & - & - & - & $R$ & - & $M$ & - & - & - & - & - & - & - & $M$ & - & - & - & - & - & - & $Y$ & - & - & - & - \\
\hline 84 & - & - & - & $R$ & - & $M$ & - & - & $Y$ & - & - & - & - & $M$ & - & - & $Y$ & - & - & - & $Y$ & - & - & - & - \\
\hline 91 & $S$ & $S$ & - & - & - & $M$ & - & - & - & $S$ & $S$ & - & - & $M$ & - & - & - & - & - & W & $Y$ & - & - & - & $Y$ \\
\hline 93 & $S$ & $S$ & - & - & - & $M$ & - & - & - & $S$ & $S$ & - & - & $M$ & - & - & - & - & - & W & $Y$ & - & - & - & $Y$ \\
\hline 94 & $S$ & $S$ & - & - & - & $M$ & - & - & - & $S$ & $S$ & - & - & $M$ & - & - & - & - & - & W & $Y$ & - & - & - & $Y$ \\
\hline 95 & - & - & - & - & - & $M$ & - & - & - & - & - & - & - & $M$ & - & - & - & - & - & W & $Y$ & - & - & - & $Y$ \\
\hline 98 & $S$ & $S$ & - & - & - & $M$ & - & - & - & $S$ & $S$ & - & - & $M$ & - & $R$ & - & - & - & W & $Y$ & - & - & W & $Y$ \\
\hline 100 & $S$ & $S$ & - & - & - & $M$ & - & - & - & $S$ & $S$ & - & - & $M$ & - & $R$ & - & - & - & W & $Y$ & - & - & W & $Y$ \\
\hline 102 & $S$ & $S$ & - & - & - & $M$ & - & - & - & $S$ & $S$ & - & - & $M$ & - & $R$ & - & - & - & W & $Y$ & - & - & W & $Y$ \\
\hline 112 & - & - & - & - & - & $M$ & - & $Y$ & - & - & - & - & - & $M$ & $Y$ & - & - & $R$ & $R$ & - & - & - & - & - & - \\
\hline 805 & - & - & - & - & - & $M$ & - & - & - & - & - & - & - & $M$ & - & - & - & - & - & W & $Y$ & - & - & - & $Y$ \\
\hline 1664 & - & - & - & - & - & $M$ & - & - & - & - & - & - & - & $M$ & - & - & - & - & - & W & $\mathrm{Y}$ & - & - & - & $\mathrm{Y}$ \\
\hline 49782 & - & - & - & - & - & - & - & - & - & - & - & - & - & - & - & - & - & - & - & - & - & - & - & - & - \\
\hline 49783 & - & - & - & - & - & - & - & - & - & - & - & - & - & - & - & - & - & - & - & - & - & - & - & - & - \\
\hline A203 & - & - & - & - & - & $M$ & - & - & - & - & - & - & - & $M$ & - & - & - & - & - & - & $\mathrm{Y}$ & - & - & - & - \\
\hline Alva & - & - & - & - & - & $M$ & - & - & - & - & - & - & - & $M$ & - & $\mathrm{R}$ & - & - & - & W & $\mathrm{Y}$ & - & - & - & $Y$ \\
\hline Gota & $S$ & $S$ & - & - & - & $M$ & - & - & - & $S$ & $S$ & - & - & $M$ & - & - & - & - & - & W & $\mathrm{Y}$ & - & - & W & $Y$ \\
\hline S1 & - & - & - & - & - & W & $S$ & $Y$ & $Y$ & - & - & - & - & W & $Y$ & - & $Y$ & - & - & - & $Y$ & - & - & - & - \\
\hline S6 & - & - & - & - & - & W & - & $\mathrm{Y}$ & $\mathrm{Y}$ & - & - & - & - & W & $Y$ & - & $Y$ & - & - & - & $\mathrm{Y}$ & - & - & - & - \\
\hline S7 & - & - & - & - & - & W & - & $Y$ & $Y$ & - & - & - & - & W & $Y$ & - & $\mathrm{Y}$ & - & - & - & $\mathrm{Y}$ & - & - & - & - \\
\hline S8 & - & - & - & - & - & W & - & $Y$ & $Y$ & - & - & - & - & W & $Y$ & - & $\mathrm{Y}$ & - & - & - & $Y$ & - & - & - & - \\
\hline Ud3 & - & - & - & - & $Y$ & $M$ & - & - & - & - & - & - & - & $M$ & - & - & - & - & - & W & $\mathrm{Y}$ & - & - & - & $Y$ \\
\hline Ud11 & - & - & - & - & $Y$ & $M$ & - & - & - & - & - & - & - & $M$ & - & - & - & - & - & W & $Y$ & - & - & - & $Y$ \\
\hline Ud18 & - & - & - & - & $Y$ & $M$ & - & - & - & - & - & - & - & $M$ & - & - & - & - & - & W & $Y$ & - & - & - & $Y$ \\
\hline
\end{tabular}


Tabela 1 (continuação)

\begin{tabular}{|c|c|c|c|c|c|c|c|c|c|c|c|c|c|c|c|c|c|c|c|c|c|c|c|c|c|}
\hline \multirow{2}{*}{ Cepa } & \multicolumn{25}{|c|}{ Posição } \\
\hline & 355 & 394 & 401 & 404 & 405 & 406 & 408 & 416 & 417 & 427 & 428 & 439 & 444 & 448 & 459 & 463 & 473 & 487 & 488 & 499 & 500 & 515 & 529 & 531 & 534 \\
\hline GenBank & $T$ & $\mathrm{C}$ & $\mathrm{T}$ & $G$ & $A$ & $G$ & $A$ & $\mathrm{~T}$ & $A$ & $\mathrm{~T}$ & $A$ & $C$ & $A$ & $A$ & $A$ & $T$ & $\mathrm{C}$ & $\mathrm{T}$ & $A$ & $G$ & $\mathrm{~T}$ & $G$ & $\mathrm{~T}$ & $G$ & $\mathrm{G}$ \\
\hline $5 \mathrm{~T}$ & - & $Y$ & - & - & $\mathrm{R}$ & $\mathrm{R}$ & M & W & $\mathrm{R}$ & - & - & - & - & - & W & - & $S$ & W & W & $\mathrm{s}$ & $\mathrm{K}$ & - & $\mathrm{K}$ & $\mathrm{K}$ & $\mathrm{R}$ \\
\hline 7T & - & $Y$ & - & - & $\mathrm{R}$ & $R$ & $M$ & W & $\mathrm{R}$ & - & - & - & - & - & W & - & S & W & W & $S$ & $\mathrm{~K}$ & - & $\mathrm{K}$ & $\mathrm{K}$ & $\mathrm{R}$ \\
\hline $7 \mathrm{~V}$ & - & - & K & $\mathrm{R}$ & - & $R$ & - & - & - & - & - & - & - & W & W & K & - & - & - & - & - & S & - & - & $\mathrm{K}$ \\
\hline $9 \mathrm{~V}$ & - & - & $\mathrm{K}$ & $\mathrm{R}$ & - & $\mathrm{R}$ & - & - & - & - & - & - & - & W & W & $\mathrm{K}$ & - & - & - & - & - & S & - & - & $\mathrm{K}$ \\
\hline 10T & - & $Y$ & - & - & $\mathrm{R}$ & $R$ & M & W & $\mathrm{R}$ & - & - & - & - & - & W & - & S & W & W & $S$ & K & S & $\mathrm{K}$ & $\mathrm{K}$ & $\mathrm{R}$ \\
\hline 13T & - & Y & - & - & $\mathrm{R}$ & $R$ & M & W & $\mathrm{R}$ & - & - & - & - & - & W & - & S & W & W & S & $\mathrm{K}$ & - & $\mathrm{K}$ & $\mathrm{K}$ & $R$ \\
\hline 15T & - & $Y$ & - & - & $\mathrm{R}$ & $R$ & $M$ & W & $\mathrm{R}$ & - & - & - & - & - & W & - & $S$ & W & W & $S$ & $\mathrm{~K}$ & - & K & K & $R$ \\
\hline $16 \mathrm{~V}$ & - & & $\mathrm{K}$ & $\mathrm{R}$ & - & $R$ & - & - & - & - & - & - & - & W & W & $\mathrm{K}$ & - & - & - & - & - & $S$ & - & - & $\mathrm{K}$ \\
\hline $18 \mathrm{~T}$ & - & Y & - & - & $R$ & $R$ & $M$ & W & $\mathrm{R}$ & - & - & - & - & - & W & $\cdots$ & $S$ & W & W & $S$ & K & - & K & K & $R$ \\
\hline $19 \mathrm{~V}$ & - & - & K & $R$ & - & $R$ & - & - & - & - & - & - & - & W & W & K & - & - & - & - & - & $S$ & - & - & $\mathrm{K}$ \\
\hline 59 & - & - & - & - & - & - & - & - & - & W & $\mathrm{R}$ & - & W & - & - & - & - & - & - & - & - & $S$ & - & - & $\mathrm{K}$ \\
\hline 64 & - & - & - & - & - & - & - & - & - & W & $R$ & - & W & - & - & - & - & - & - & - & - & $S$ & - & - & $\mathrm{K}$ \\
\hline 72 & $\mathrm{~K}$ & $Y$ & - & - & - & $R$ & - & - & - & W & $R$ & $M$ & - & W & - & - & - & - & - & - & - & $S$ & - & - & $R$ \\
\hline 73 & $\mathrm{~K}$ & $Y$ & - & - & - & $R$ & - & - & - & W & $R$ & $M$ & - & W & - & - & - & - & - & - & - & $S$ & - & - & $R$ \\
\hline 74 & K & $Y$ & - & - & - & $R$ & - & - & - & W & $R$ & M & - & W & - & - & - & - & - & - & - & $S$ & - & - & $\mathrm{R}$ \\
\hline 77 & $\mathrm{~K}$ & $Y$ & - & - & - & $R$ & - & - & - & W & $R$ & $M$ & - & W & - & - & - & - & - & - & - & $S$ & - & - & $R$ \\
\hline 84 & $\mathrm{~K}$ & $Y$ & - & - & - & $R$ & - & - & - & W & $R$ & M & - & W & - & - & - & - & - & - & - & $R$ & - & - & $R$ \\
\hline 91 & - & - & K & $\mathrm{R}$ & - & $\mathrm{R}$ & - & - & - & - & - & - & - & W & W & $\mathrm{K}$ & - & - & - & - & - & $S$ & - & - & $\mathrm{K}$ \\
\hline 93 & - & - & K & $\mathrm{R}$ & - & $R$ & - & - & - & - & - & - & - & W & W & $\mathrm{K}$ & - & - & - & - & - & $S$ & - & - & $\mathrm{K}$ \\
\hline 94 & - & - & $\mathrm{K}$ & $\mathrm{R}$ & - & $R$ & - & - & - & - & - & - & - & W & W & $\mathrm{K}$ & - & - & - & - & - & $S$ & - & - & $\mathrm{K}$ \\
\hline 95 & - & - & $\mathrm{K}$ & $\mathrm{R}$ & - & $R$ & - & - & - & - & - & - & - & W & W & $\mathrm{K}$ & - & - & - & - & - & $S$ & - & - & $\mathrm{K}$ \\
\hline 98 & - & - & K & $R$ & - & $R$ & - & - & - & - & - & - & - & W & W & $\mathrm{K}$ & - & - & - & - & - & $S$ & - & - & $\mathrm{K}$ \\
\hline 100 & - & - & $\mathrm{K}$ & $\mathrm{R}$ & - & $R$ & - & - & - & - & - & - & - & W & W & $\mathrm{K}$ & - & - & - & - & - & $S$ & - & - & $\mathrm{K}$ \\
\hline 102 & - & - & K & $\mathrm{R}$ & - & $R$ & - & - & - & - & - & - & - & W & W & $\mathrm{K}$ & - & - & - & - & - & $S$ & - & - & $\mathrm{K}$ \\
\hline 112 & - & - & - & - & $R$ & $R$ & $R$ & - & $\mathrm{R}$ & - & - & - & - & W & W & - & - & $Y$ & - & - & - & $S$ & - & - & $\mathrm{R}$ \\
\hline 805 & - & - & - & - & - & $R$ & - & - & - & - & - & - & - & W & W & - & - & - & - & - & - & S & - & - & $\mathrm{K}$ \\
\hline 1664 & - & - & - & - & - & $\mathrm{R}$ & - & - & - & - & - & - & - & W & W & - & - & - & - & - & - & $S$ & - & - & $\mathrm{K}$ \\
\hline 49782 & - & - & - & - & - & - & - & - & - & - & - & - & - & - & - & - & - & - & - & - & - & - & - & - & - \\
\hline 49783 & - & - & - & - & - & - & - & - & - & - & - & - & - & - & - & - & - & - & - & - & - & - & - & - & $\mathrm{K}$ \\
\hline A203 & - & - & - & - & - & $\mathrm{R}$ & - & - & - & - & - & - & - & - & - & - & S & - & - & $S$ & K & S & - & - & $\mathrm{K}$ \\
\hline Alva & - & - & $\mathrm{K}$ & $\mathrm{R}$ & - & $\mathrm{R}$ & - & - & - & - & - & - & - & W & W & $\mathrm{K}$ & - & - & - & - & - & $S$ & - & - & $\mathrm{K}$ \\
\hline Gota & - & - & $\mathrm{K}$ & $\mathrm{R}$ & - & $\mathrm{R}$ & - & - & - & - & - & - & - & W & W & K & - & - & - & - & - & $S$ & - & - & $\mathrm{K}$ \\
\hline $\mathrm{S} 1$ & - & - & - & - & - & - & - & - & - & W & $\mathrm{R}$ & - & W & - & - & - & - & - & - & - & - & $S$ & - & - & - \\
\hline S6 & - & - & - & - & - & - & - & - & - & W & $\mathrm{R}$ & - & W & - & - & - & - & - & - & - & - & $S$ & - & - & - \\
\hline S7 & - & - & - & - & - & - & - & - & - & W & $\mathrm{R}$ & - & W & - & - & - & - & - & - & - & - & $S$ & - & - & - \\
\hline S8 & - & - & - & - & - & - & - & - & - & W & $\mathrm{R}$ & - & W & - & - & - & - & - & - & - & - & $S$ & - & - & - \\
\hline Ud3 & - & - & $\mathrm{K}$ & $\mathrm{R}$ & - & $\mathrm{R}$ & - & - & - & - & - & - & - & W & W & $\mathrm{K}$ & - & - & - & - & - & $S$ & - & - & K \\
\hline Ud11 & - & - & $\mathrm{K}$ & $\mathrm{R}$ & - & $\mathrm{R}$ & - & - & - & - & - & - & - & W & W & $\mathrm{K}$ & - & - & - & - & - & $S$ & - & - & $\mathrm{K}$ \\
\hline Ud18 & - & - & $\mathrm{K}$ & $\mathrm{R}$ & - & $\mathrm{R}$ & - & - & - & - & - & - & - & W & W & $\mathrm{K}$ & - & - & - & - & - & $S$ & - & - & $\mathrm{K}$ \\
\hline
\end{tabular}

-indica um nucleotídeo idêntico ao respectivo, indicado pela posição referente no gene 16S rRNA / Polimorfismos estão indicados pelas letras $\mathrm{Y}$, $\mathrm{R}$, M, $\mathrm{K}$, W, 


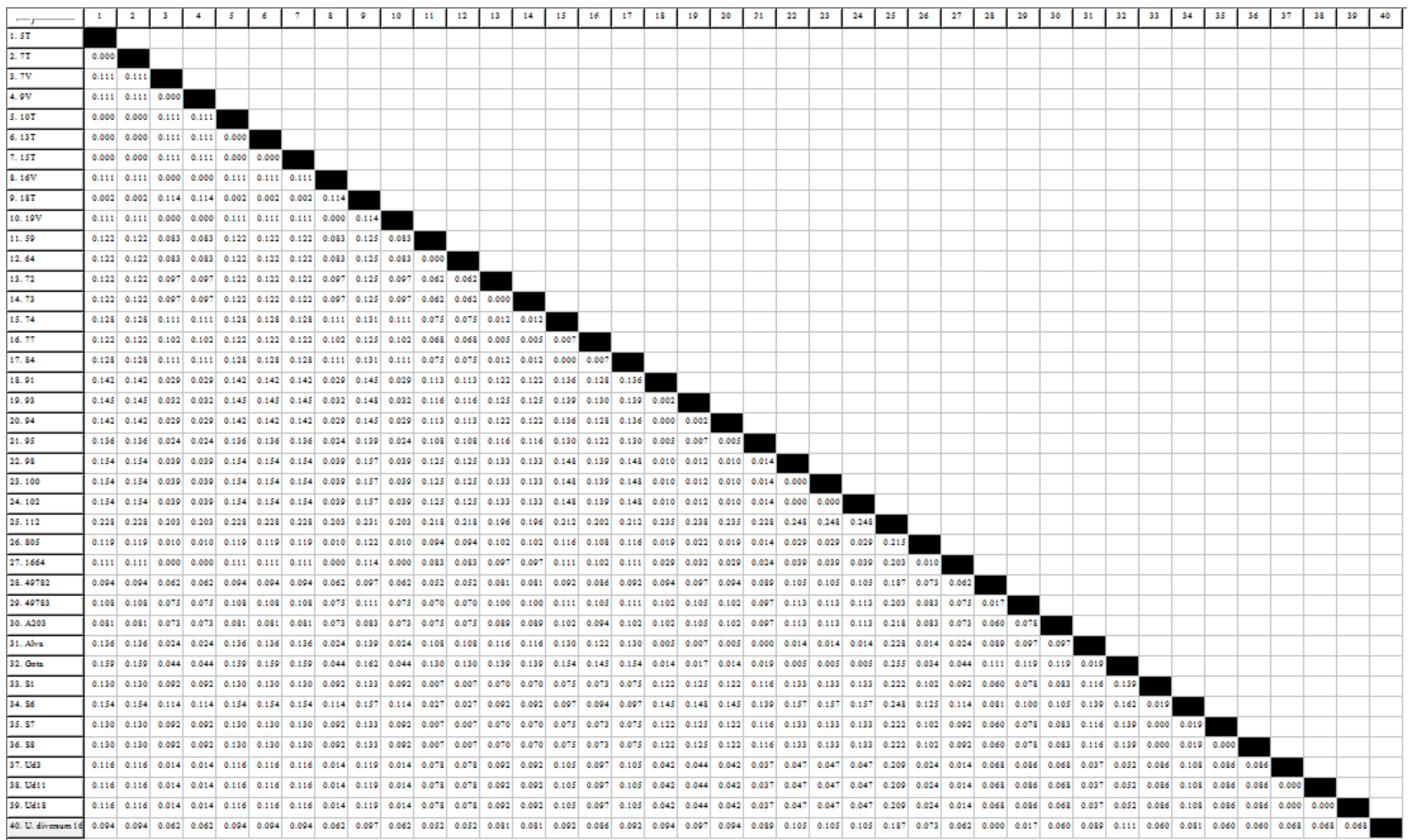

Figura 4. Análise de similaridade da seqüência parcial do gene $16 \mathrm{~S}$ de isolados e cepas de U. diversum e seqüência 16S rRNA depositada no GenBank, realizada pelo método Clustal-W do programa MEGA -4. 


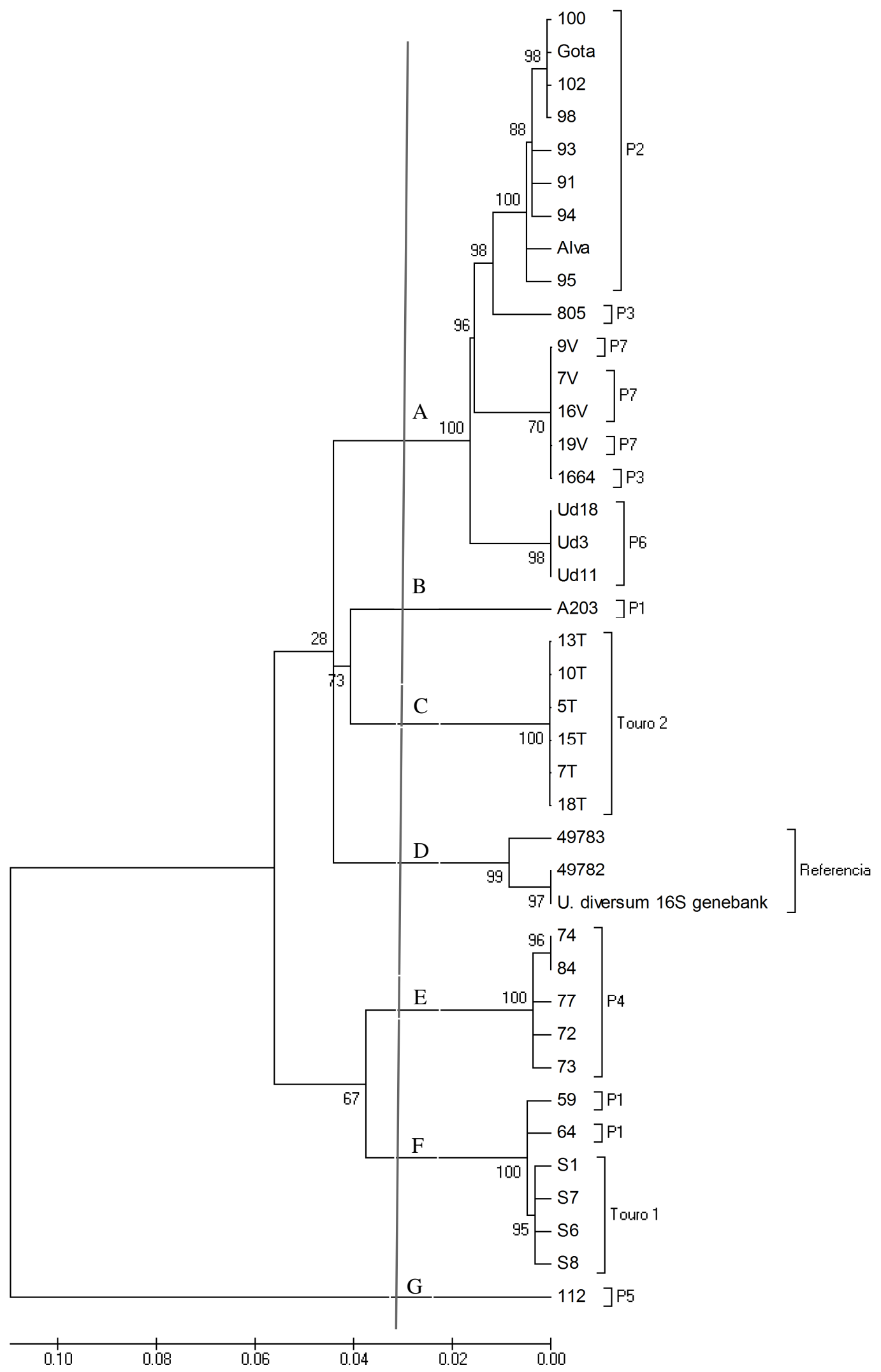

Figura 5. Dendograma obtido com as seqüências parciais do gene 16S rRNA (5'- 3') das cepas e isolados de $U$. diversum e seqüência completa do 16S rRNA do $U$. diversum depositada no GenBank. O método de construção foi calculado pelo algoritmo "Neighbor-Joining" com "Bootstrap" de 1.000 repetições. 


\subsection{PCR do gene da Urease}

Na PCR, com os "primers" do gene urease, foi obtido um produto de 458 pb em 16 isolados e duas cepas de referência (Figura 6). Quatorze isolados não apresentaram produtos na PCR e, desta forma, a análise de agrupamento e construção de dendrograma não foi realizada.

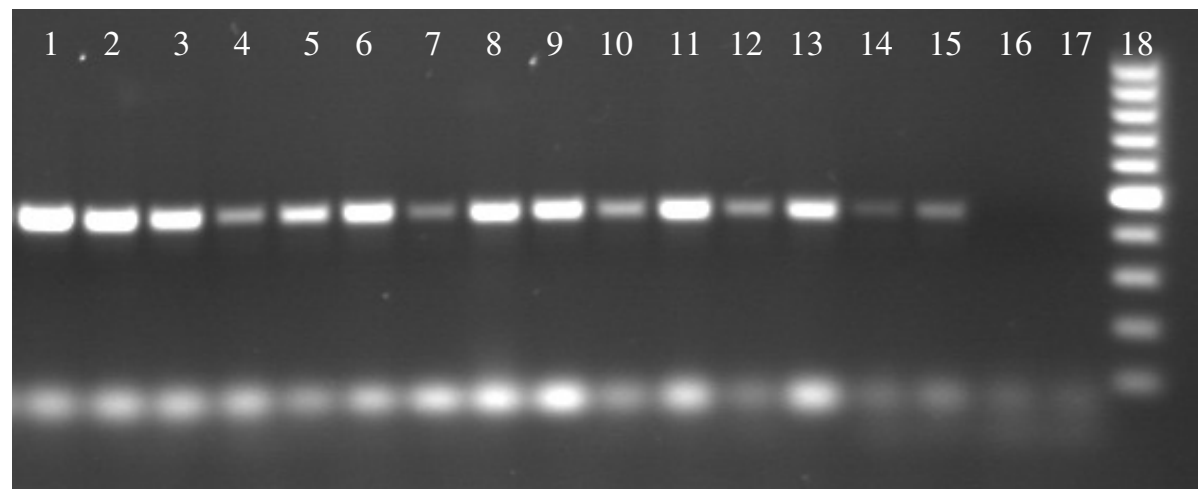

Figura 6. Eletroforese em gel de agarose dos produtos amplificados na PCR utilizando "primers" 14b e 72c com DNA dos isolados e das cepas de referência de $U$. diversum. Colunas 1 a 15: amostras amplificadas; Coluna 16: amostra não amplificada; Coluna 17: controle negativo; Coluna 18: peso molecular 100 pb.

\subsection{Avaliação dos fatores de virulência de Ureaplasma diversum}

\subsubsection{Presença de cápsula}

As células de $U$. diversum, a partir de cultivo, apresentaram uma camada densa externa à da membrana celular dos microrganismos estudados. Esta estrutura apresentou-se difusa e amorfa, estendendo 11 a $17 \mathrm{~nm}$ a partir da membrana em todas as cepas e isolados analisados(Figura 7). Este material polissacarídico foi observada em menor intensidade, internamente a membrana celular, o que pode indicar uma secreção deste material momento do cultivo. 

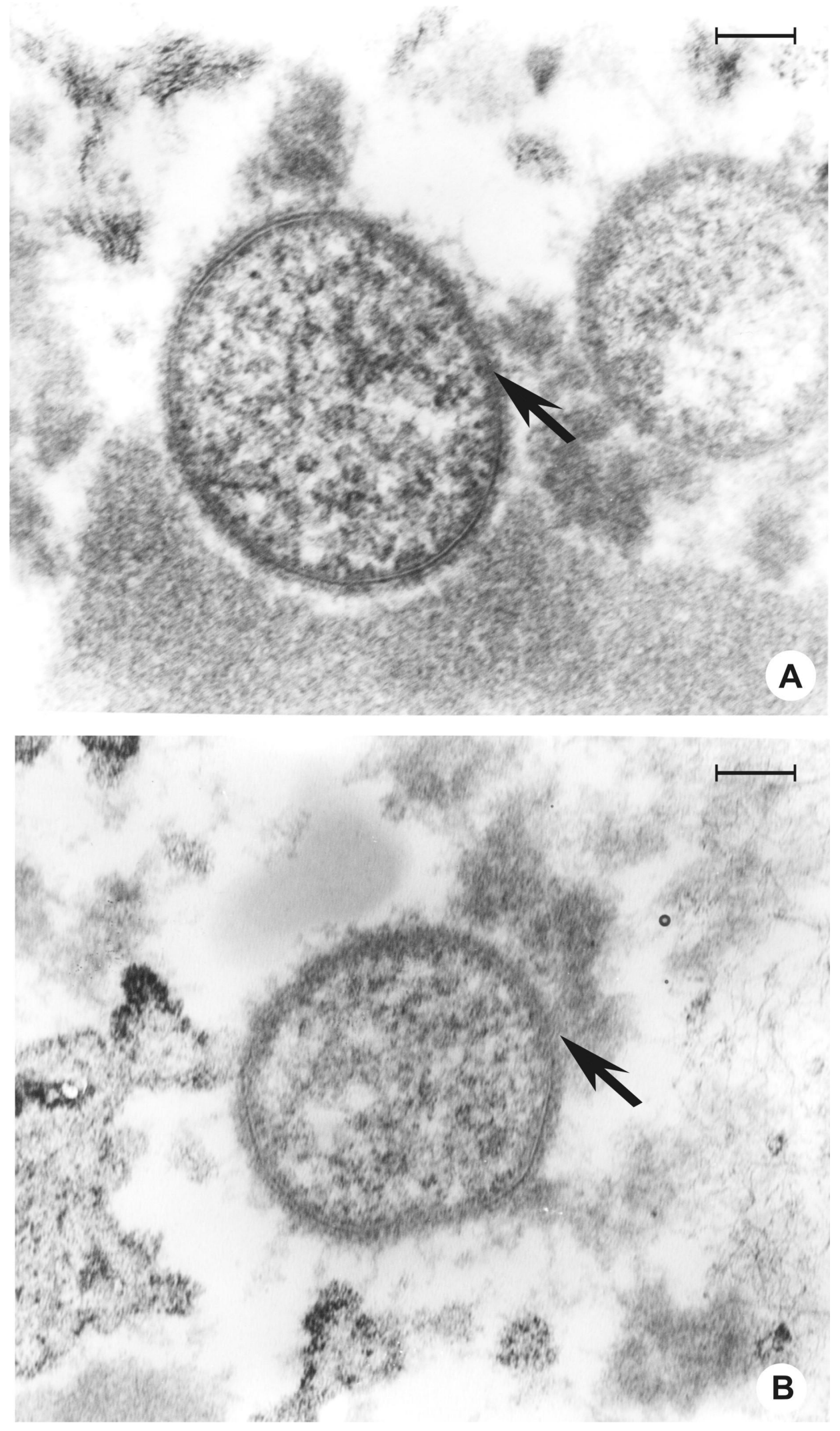

Figura 7. Microscopia eletrônica de células de U. diversum, obtidas no cultivo de isolados provenientes de mucovulvovaginal e sêmen bovino, tratadas com vermelho de ruteno, evidenciando material polissacarídico. A) isolado 77 (vaca); B) isolado 10T (touro). Barra $100 \mathrm{~nm}$. 


\subsubsection{Fosfofolipase C}

No teste qualitativo, os ureaplasmas estudados foram classificados quanto a atividade de fosfolipase $\mathrm{C}$ em alta, média e baixa, conforme a intensidade de fluorescência emitida. Das amostras analisadas, 18 (50,0\%) apresentaram alta, 14 (33,3\%) média e 7 (16,7\%) baixa atividade (Figura 8).

No teste quantitativo, cinco (13,9\%) isolados de ureaplasma apresentaram baixa atividade (hidrólise de pNPPC entre 0,292 a 0,409 U mg-1 proteína) e 31 (86,1\%) alta atividade desta enzima (hidrólise 2,476 de 3,396 U $\mathrm{mg}^{-1}$ proteína). Não foi possível detectar a atividade do isolado $9 \mathrm{~V}$ devido à inviabilidade no cultivo. Os isolados com baixa atividade eram provenientes de duas propriedades e centros de inseminação, sendo dois obtidos de muco vulvovaginal (Ud3 e Ud8) e três de sêmen de palhetas (S1, S7 e 15T) (Figura 9). A figura 10 ilustra a alta atividade de fosfolipase $C$ nas cepas e isolados.

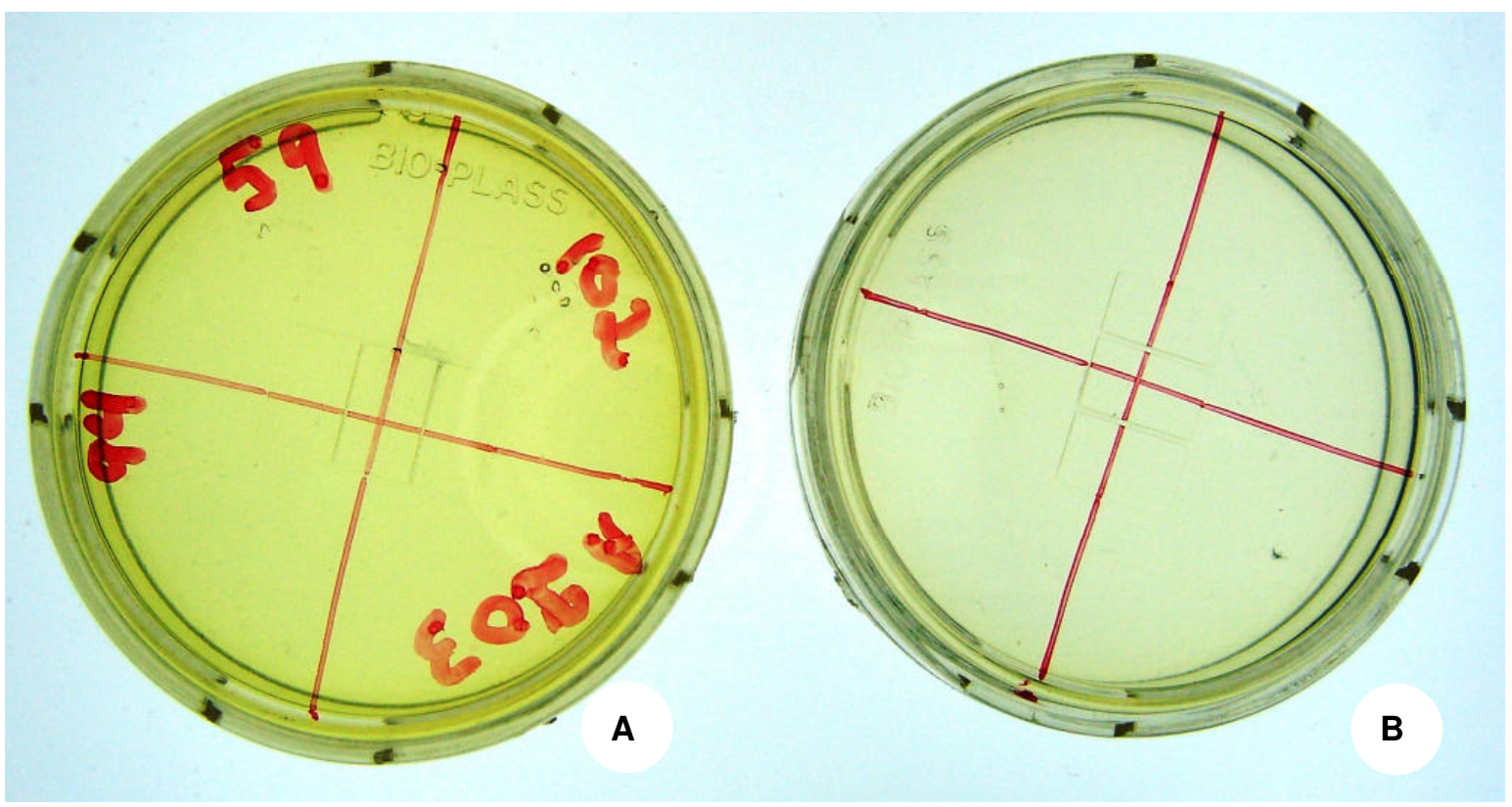

Figura 8. Evidência de alta atividade de fosfolipase de isolados de $U$. diversum. A) Amostras fosfolipase positiva; B) Controle negativo. 


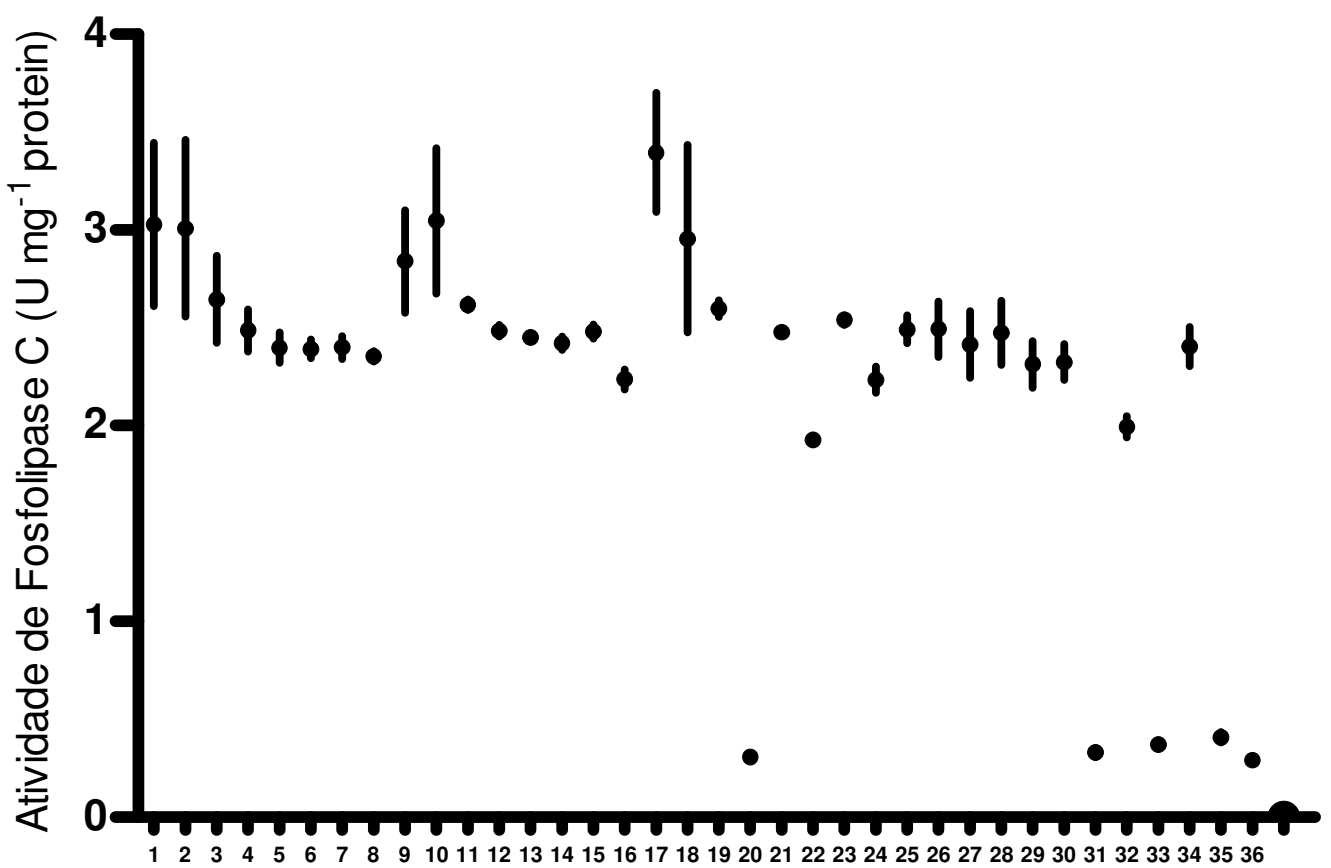

Amostras

Figura 9. Atividade de fosfolipase $\mathrm{C}$ avaliada nas cepas e isolados de $U$. diversum estudadas. A absorbância foi determinada em $405 \mathrm{~nm}$ após $24 \mathrm{~h}$ de incubação a $37^{\circ} \mathrm{C}$ em meio UB com pNPPC.

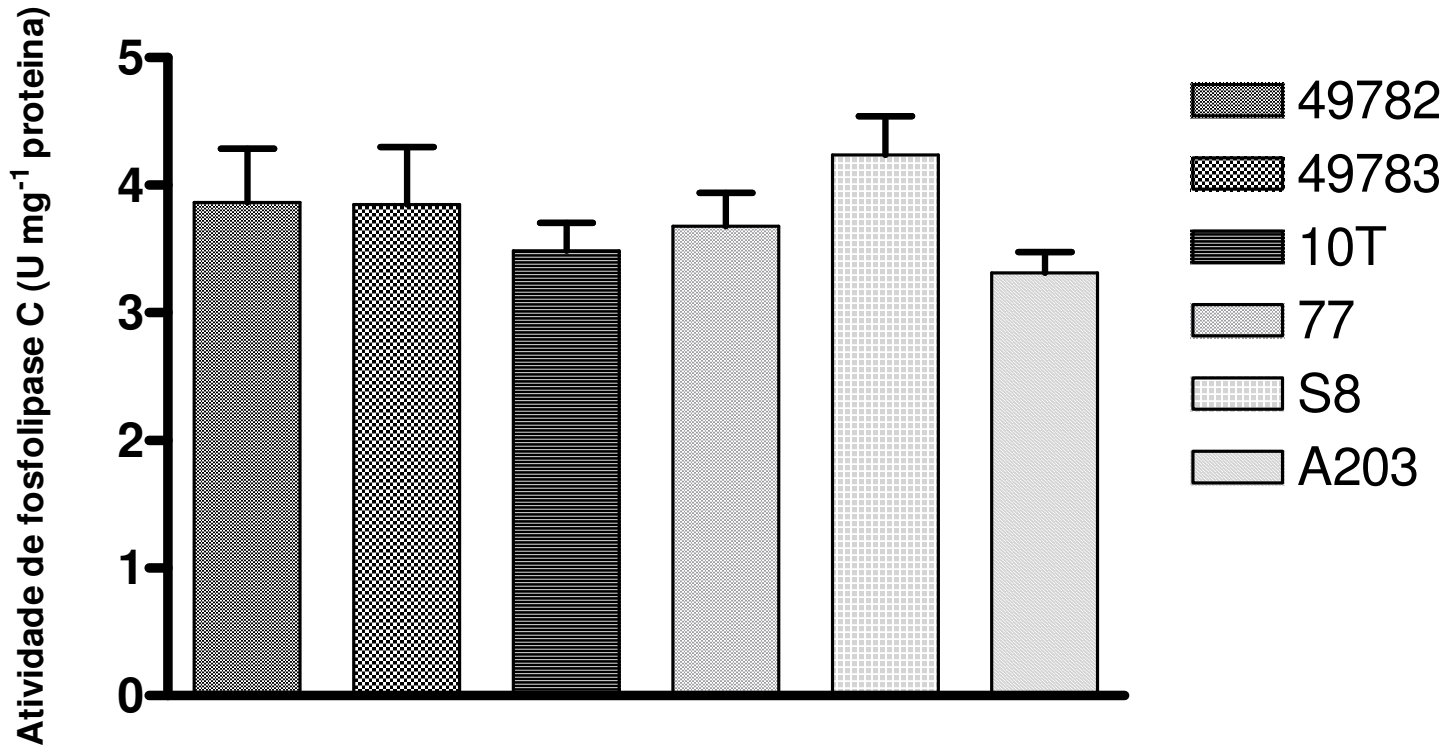

\section{Amostra}

Figura 10. Atividade de fosfolipase $C$ avaliada nas cepas e isolados de $U$. diversum estudadas no teste de adesão e invasão. A absorbância foi determinada em $405 \mathrm{~nm}$ após $24 \mathrm{~h}$ de incubação a $37^{\circ} \mathrm{C}$ em meio UB com pNPPC. 


\subsubsection{Atividade de $\lg \mathrm{A}$ protease}

Não houve diferença nos perfis proteícos das cepas e isolados de $U$. diversum incubados com os da IgA quando comparado com a cepa ou isolado analisado sem a incubação com a slgA e a slgA, indicando ausência de atividade de IgAse nas culturas estudadas (Figura 11).
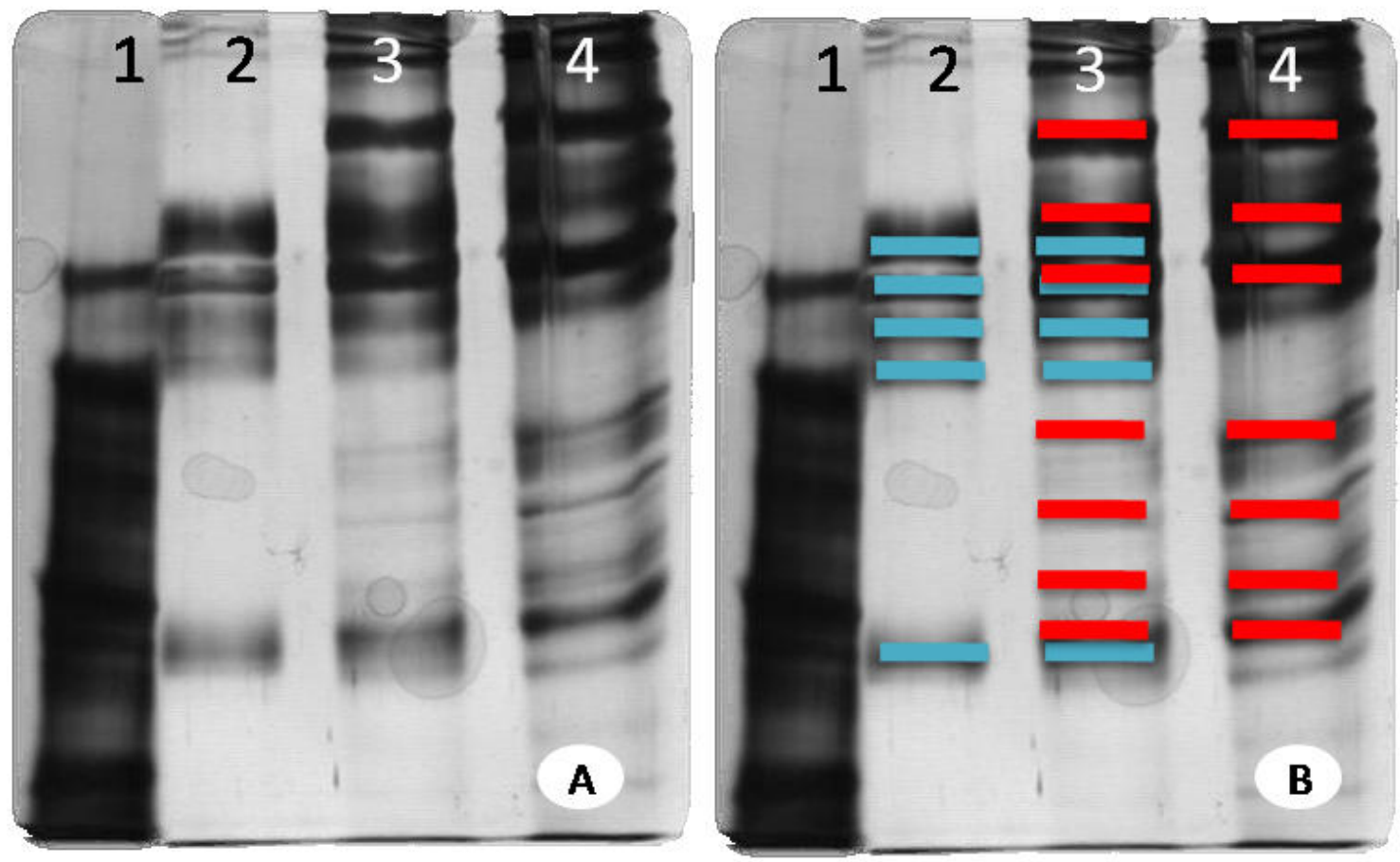

Figura 11. Perfis protéicos $(A)$ e representação esquemática $(B)$ de IgA bovina após exposição por 24 h com cepa 49782 de U. diversum. Colunas 1: Padrão de peso molecular; Colunas 2: perfil protéico obtido do U. diversum 49782; Colunas 3: perfis protéicos obtido após $24 \mathrm{~h}$ de incubação do U. diversum 49782 incubado com a slgA bovina; Colunas 4: slgA bovina.

\subsubsection{Adesão e invasão em células Hep-2}

As células infectadas não apresentaram efeito citopático nos períodos de infecção estudados. O fluocromo Vybrant Dil não apresentou citotoxicidade bacteriana, pois foi verificado a viabilidade dos ureaplasmas após a marcação com fluorocromo (dados não mostrados). 
Não foi observado fluorescência intracelular do Vybrant Dil $C$ em células Hep-2 marcadas com FITC e não infectadas. Imagens obtidas no microscópio confocal variando da região basal a apical da célula, evidenciaram a coloração verde da actina e azul da luminescência obtida no DNA.

As imagens das células Hep-2 infectadas evidenciaram a presença de ureaplasmas aderidos a membrana e no espaço citoplasmático (Figura 12). Os ureaplasmas marcados foram detectados em vermelho, distinguindo-se da actina e do DNA. Após um minuto de infecção, poucos ureaplasmas foram visualizados no citoplasma das células Hep-2 (Figura 12.1). Após 30 min de infecção, a concentração de ureaplasmas dispersos no citoplasma da célula foi maior. Nos períodos de 3, 8 e $12 \mathrm{~h}$ de infecção, os microrganismos foram detectados em maior concentração na região perinuclear (Figura 12.3 e 12.4). As cepas e isolados de $U$. diversum não apresentaram perfil de adesão e invasão diferentes nos períodos de infecção analisados.

Evidências adicionais da invasão de $U$. diversum em células Hep-2 foram observadas na figura $13 \mathrm{~A}$, com a presença de fluorescência vermelha em diferentes secções, incluindo aquelas relacionadas à região citoplasmática. $\mathrm{Na}$ figura 13B, com os cortes ortogonais de células Hep-2, após três horas de infecção, a fluorescência vermelha pôde ser detectada no citoplasma desde a região apical à basolateral da célula e no espaço perinuclear. A confirmação da presença dos ureaplasmas no espaço perinuclear foi realizada com o software Imaris 3.1.3 (Bitplane AG) que resultou na representação gráfica da fluorescência (Figura 13C).

$\mathrm{Na}$ figura 14 pôde-se observar a localização perinuclear dos ureaplasmas, evidenciado pela sua proximidade à proteína nuclear lamina, sem comprovação da invasão nuclear.

Previamente a realização do teste da gentamicina, as cepas foram expostas a $400 \mu \mathrm{g} / \mathrm{mL}$ do antibiótico e não apresentaram crescimento quando inoculadas em meio UB,.confirmando a sua ação bactericida. A internalização dos ureaplasmas em células Hep-2 foi confirmada pelo teste da gentamicina. Este antibiótico, impermeável às células mamárias na concentração utilizada, impediu o crescimento nos subcultivos, em meio UB líquido, dos ureaplasmas 
localizados na região extracelular. As taxas de invasão, expressas na porcentagem de CCU, obtidas após a inoculação do antibiótico na célula, em relação ao inóculo inicial, estão sumarizados na Tabela 2. Os resultados mostraram que aproximadamente $1 \%$ do inóculo inicial sobreviveu ao tratamento da gentamicina nas cepas de referência (ATCC 49782 e 49783) e $10 \%$ nos isolados clínicos. As cepas ATCC possuem alta passagem apresen taram taxas de invasão inferiores aos isolados ( $p$-valor $<2.2 \mathrm{e}-16$, teste de igualdade de proporções com correção de continuidade, R project, Vienna, Austria). Não foram observadas diferenças nas taxas de invasão entre os isolados de alta e baixa passagem ( $p$-value $<2.2 \mathrm{e}-16$ ). 


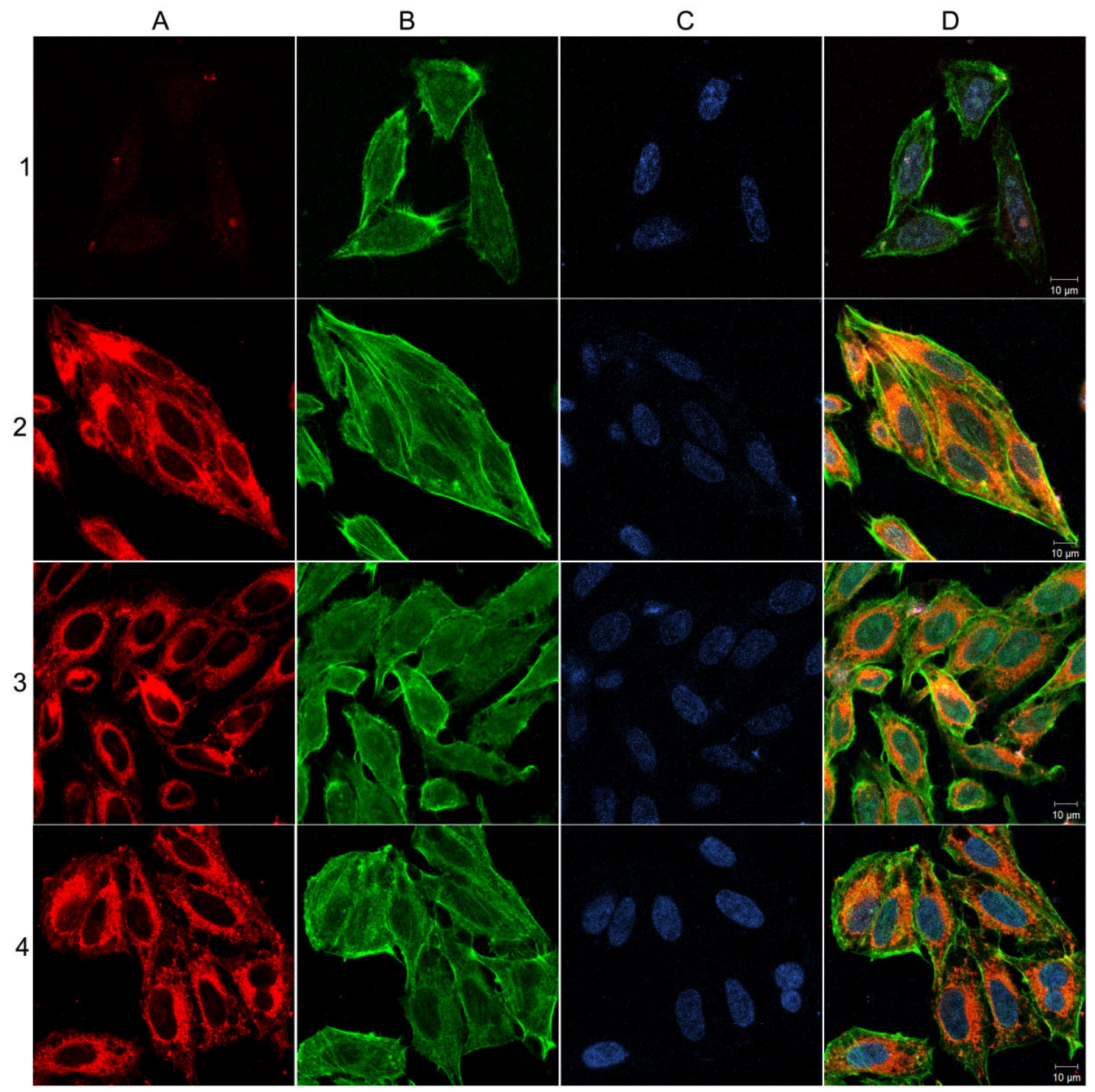

Figura 12. Microscopia confocal evidenciando a internalização de $U$. diversum em células Hep2 após $1 \mathrm{~min}(1), 30 \mathrm{~min}(2), 3 \mathrm{~h} \mathrm{(3)} \mathrm{e} 12$ h (4) de infecção. Ureaplasmas foram marcados com Vibrant Dil (vermelho, A), filamentos de actina de HEp-2 foram marcados com FITC (verde, B) e o núcleo das células Hep-2 marcado com TOPRO-3 (azul, C). Em D, sobreposição das imagens A, B, e C. 


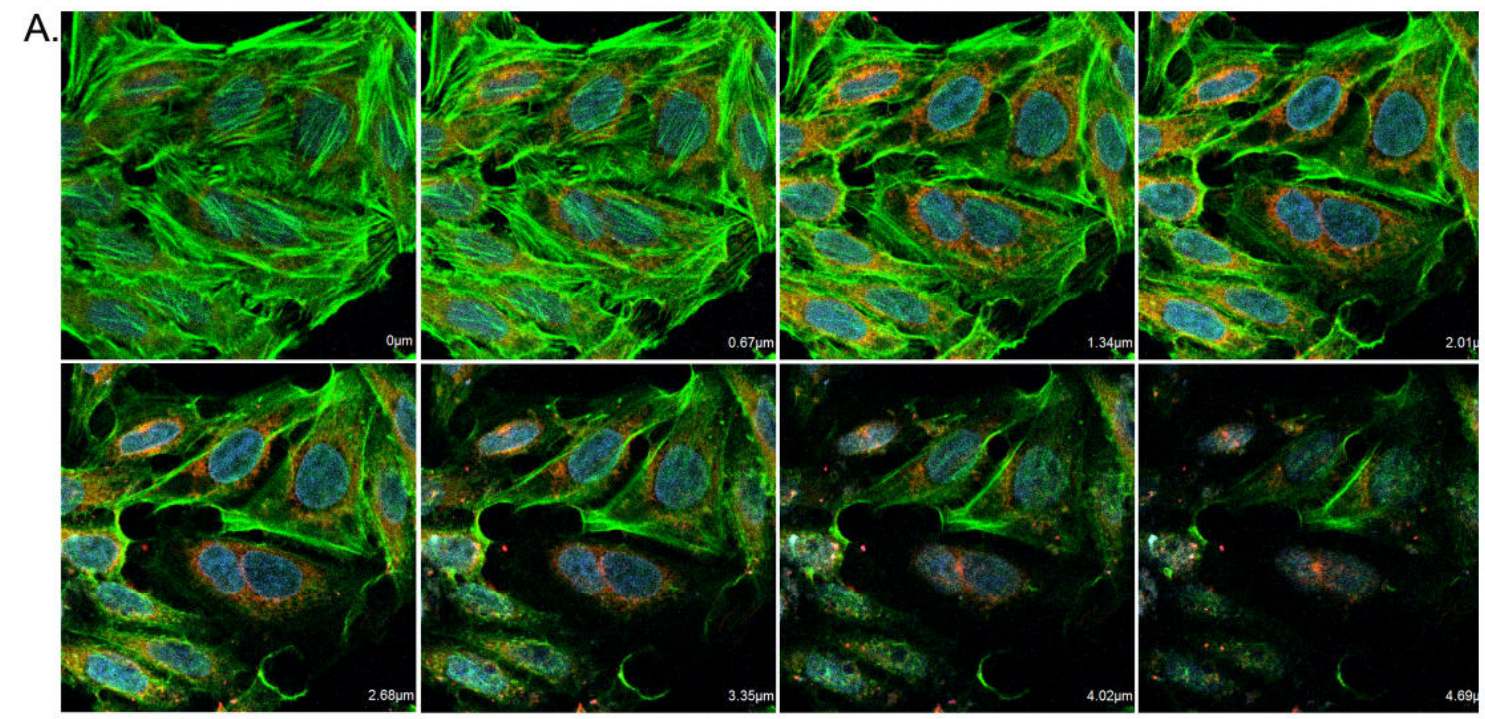

B.

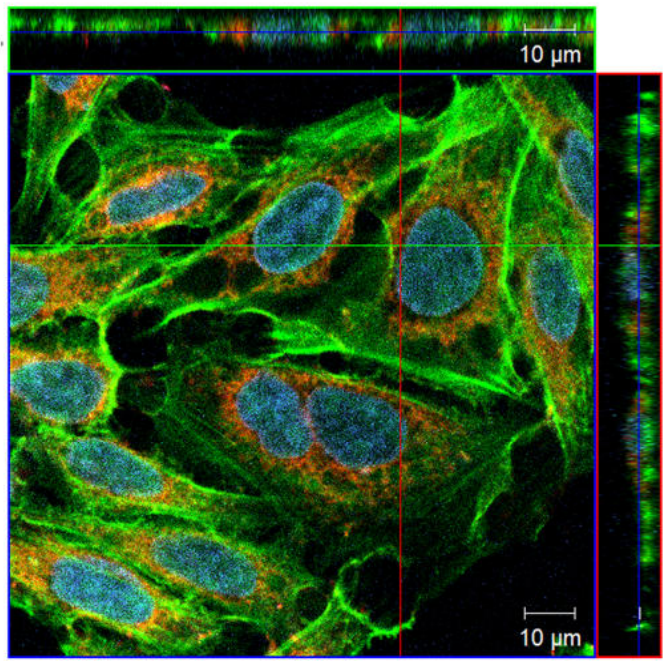

C.
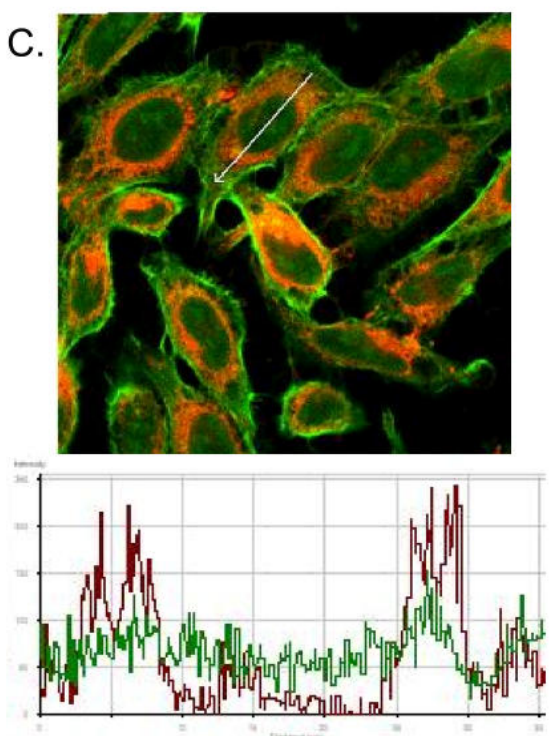

Figura 13. Microscopia confocal evidenciando a internalização de $U$. diversum em células HEp2. Ureaplasmas foram marcados com Vibrant Dil (vermelho), filamentos de actina de HEp-2 foram marcados com FITC (verde) e o núcleo das células Hep-2 marcado com TO-PRO-3 (azul). A e B: secções ópticas (A) e projeções ortogonais (B) evidenciando a presença e distribuição dos ureaplasmas no interior de células Hep2. C: Imagem e representação gráfica obtidas da localização dos ureaplasmas no interior de células Hep-2 após 12 h de infecção (picos em vermelhos) em um região perinuclear. 


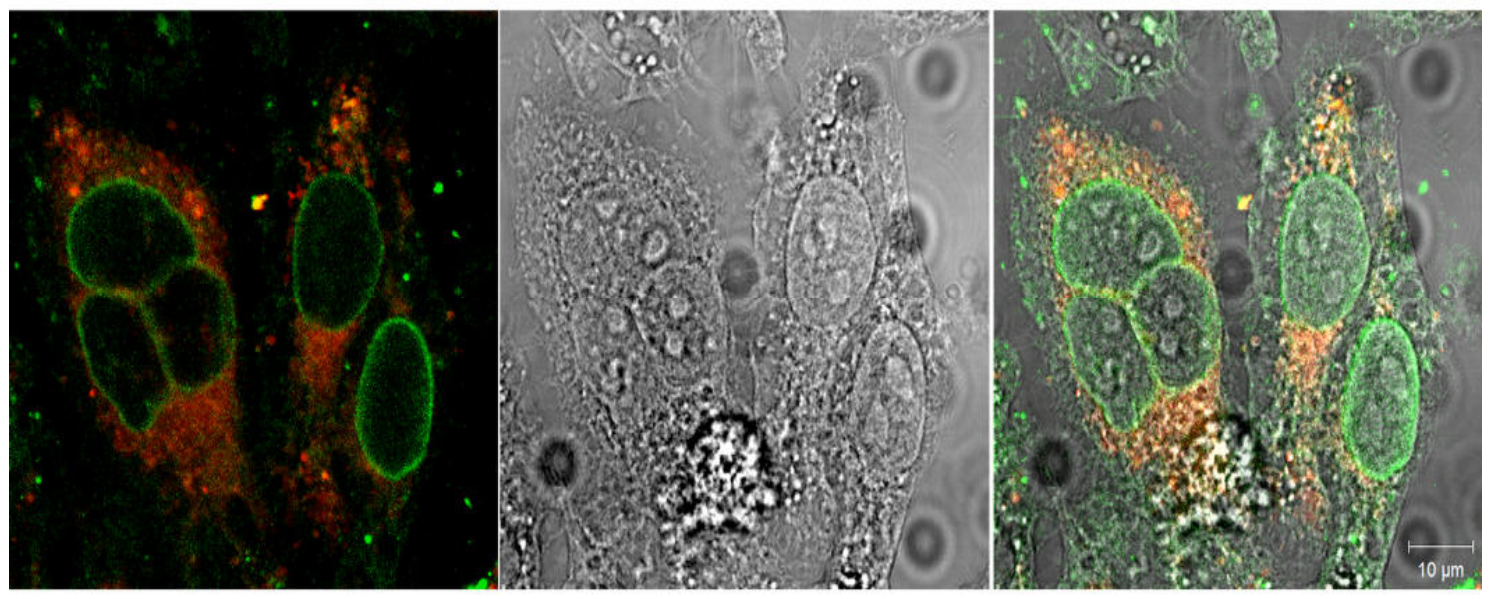

Figura 14. Células Hep-2 infectadas e submetidas a imunoflorescência com anticorpo antilamina (verde), evidenciando os ureaplasmas (vermelho) em região perinuclear.

Tabela 2. Taxas de invasão das cepas e isolados de $U$. diversum inoculadas em células Hep-2.

\begin{tabular}{cccc}
\hline Cepa & CCU inoculado & $\begin{array}{c}\text { CCU depois } \\
\text { tratamento com } \\
\text { gentamicina }\end{array}$ & \% invasão \\
\hline 49782 & $10^{6}$ & $10^{4}$ & 1.0 \\
49783 & $10^{7}$ & $10^{5}$ & 1.0 \\
$10 T$ & $10^{5}$ & $10^{4}$ & 10.0 \\
77 & $10^{5}$ & $10^{4}$ & 10.0 \\
S8 & $10^{4}$ & $10^{3}$ & 10.0 \\
A203 & $10^{4}$ & $10^{3}$ & 10.0 \\
\hline
\end{tabular}




\section{DISCUSSÃO}

Os ureaplasmas são pouco estudados no Brasil e em outros países, sendo as informações nacionais sobre ocorrência, epidemiologia e patogenicidade escassas. Desta forma, controle da ureaplasmose na pecuária bovina é inadequado e resulta em prejuízo econômico.

No presente estudo, a seqüência 16S rRNA dos ureaplasmas, isolados de animais sadios e apresentando distúrbios apresentou grande número de polimorfismo quando comparada à sequência depositada no GenBank, que constata a existência de variação intraespecífica entre os isolados de $U$. diversum. A presença de polimorfismos tem sido descrita nas espécies da Classe Mollicutes (BUIM et al., 2008; KÖNIGSSON et al., 2002). Königsson et al. (2002) sequenciaram produtos amplificados das regiões U1 e U8 do gene 16S rRNA, de 17 isolados de $M$. agalactiae e oito do $M$. bovis, encontrando 21 e 12 posições polimórficas, respectivamente. Estas espécies são estreitamente relacionadas geneticamente, porém, possuem alta variabilidade no gene 16S rRNA. M. agalactiae apresentou maior taxa de variabilidade no gene $16 \mathrm{~S}$ rRNA quando comparado com outros micoplasmas isolados de ruminantes, como $M$. bovis, M. bovirhinis e M. alkalescens (PETTERSSOM et al., 1996).

Buim et al. (2008) observaram que o número de polimorfismo variou entre zero e seis, quando analisaram um fragmento de 207 pb no gene 16S rRNA de M. synoviae, observando-se que a cepa vacinal apresentou maior número de polimorfismos quando comparada às outros isolados. A causa da diversidade genotípica encontrada entre as amostras não foi identificada.

As cepas de $M$. capripneumoniae apresentaram grande número de polimorfismos no gene 16S rRNA, onde verificou-se que 11 posições polimórficas foram comuns a todos isolados investigados. Além disso, os polimorfismos encontrados foram maiores quando comparados a outras espécies do cluster M. mycoides (HELDTANDER et al., 2001; PETTERSSON et al., 1998).

As conseqüências das variações genotípicas nas funções biológicas dos ureaplasmas são desconhecidas, bem como as causas da ocorrência da diversidade encontrada. Diversos fatores podem estar relacionados à presença 
destes polimorfismos, como a organização dos genes da síntese de rRNA. Estes genes apresentam organização multigênica em operon, sendo sua quantidade variável conforme a espécie bacteriana (CILIA et al., 1996). Mycobacterium smegmatis apresenta duas cópias de rDNA por genoma (SUZUKI e YAMADA, 1988). No entanto, foi observada a presença de sete destas cópias em Escherichia coli e Salmonella typhimurium (HILL e HARNISH, 1981) e nove em Bacilllus subtillis (LOUGHNEY et al., 1982). Os molicutes também apresentam a organização em operons, sendo que possuem uma a duas cópias de rDNA e a organização destes pode diferir de outros microrganismos (AMIKAN et al., 1984).

Cilia et al. (1996) observaram que as diferenças entre as sete cópias de rDNA de $E$. coli estavam localizadas em regiões específicas, de alta taxa de variação evolucionária, mas que não alterariam a estrutura secundária da proteína. Além disto, os autores relacionaram a presença dos polimorfismos com os seguintes fenômenos: presença de organização multigênica originária de taxon divergentes, estabilização de mutação randômica, conversão genética entre os multigenes ou transferência lateral de genes. Nos molicutes, o polimorfismo nas seqüências do gene $16 \mathrm{~S}$ rRNA pôde ser relacionado à presença de mais de um operon rRNA (PETTERSSON et al., 1996; HELDTANDER et al., 1998; PETTERSSON et al.,1994).

O mecanismo de reparo dos molicutes pode ser outro fator relacionado à presença de polimorfismos, pois estes microrganismos apresentam maior porcentagem de mutações quando comparado a outras bactérias (WOESE et al.,1995). Königsson et al. (2002) descreveram que a perda dos mecanismos de reparo poderia explicar as sucessivas alterações nas bases do DNA, induzindo a mutações. Os principais tipos de sistemas que efetuam o reparo de DNA, como fotoreativação enzimática, excisão de bases por endonucleases e exonucleases de restrição e sistema pós replicativo ou recombinacional, estão ausentes nos molicutes (ROCHA e BLANCHARD, 2002).

$A$ variabilidade genotípica pode estar relacionada à freqüente ocorrência de elementos repetitivos ou inserções de seqüências nos genoma dos molicutes (BUZINHANI, 2006). A integração de seqüências virais no cromossoma, como descrito em Spiroplasma citri, pode resultar em variação intraespecífica no tamanho do genoma (BÉBÉAR et al., 1996). 
No presente estudo, a presença de polimorfismos no gene 16S rRNA proporcionou a análise discriminatória entre os ureaplasmas estudados. As cepas e isolados foram divididas em sete grupos, definidos de acordo com perfil de polimorfismos similares ou idênticos. Pettersson et al. (1998), observaram no sequenciamento do gene 16S rRNA um marcador discriminatório entre isolados de $M$. capripneumoniae em diversas regiões da África. Da mesma forma, Heldtander et al. (2001) relacionaram a presença de polimorfismos como excelentes marcadores para estudos epidemiológicos.

As cepas e isolados das propriedades 1, 2, 3, 4 e 5 do presente estudo, foram previamente submetidas a análise de variação genotípica por meio das metodologias de PFGE e AFLP (BUZINHANI et al., 2007a; BUZINHANI et al., 2007b). Os isolados pertencentes à propriedade 2 foram agrupados no mesmo "cluster" na PFGE e AFLP, semelhantemente ao grupo obtido na análise do seqüenciamento do gene 16S rRNA no presente estudo. Os isolados das propriedades 1, 3 e 4 não apresentaram o mesmo critério de agrupamento no estudo de variação pela PFGE e AFLP e no sequenciamento. $\mathrm{Na}$ análise de similaridade, cada "cluster" foi formado por isolados de uma mesma propriedade, com exceção dos isolados da propriedade 1, que foram distribuídos em diferentes "clusters". A presença de variação genotípica nos isolados de $U$. diversum assemelha-se aos resultados apresentados por Mygind et al. (1998) que observaram heterogeneidade entre isolados de $M$. hominis, quando estas cepas foram analisadas pela metodologia de sequenciamento do gene 16S rRNA. No presente estudo, não foi possível correlacionar a heterogeneicidade dos microrganismos isolados de animais sadios e doentes, bem como, com fatores de virulência das cepas e isolados estudados.

$\mathrm{O}$ isolado 112, obtido no Estado de Alagoas, permaneceu em um "cluster" separado das cepas e isolados analisados no presente estudo. Buzinhani (2006) não obteve resultados com este isolado nas metodologias de PFGE e AFLP, no entanto, este isolado foi tipificado como $U$. diversum por meio de inibição metabólica com soros hiperimunes das referência 49782 e 49783. Apesar do isolado 112 ser identificado sorologicamente como $U$. diversum, sua variação genotípica sugere a possibilidade de indentifica-lo como outra espécie no Gênero Ureaplasma. 
No presente estudo, não foi possível a amplificação do gene da urease em todos isolados, que pode ser devido à presença de identidade parcial neste gene entre o $U$. urealyticum e $U$. diversum, uma vez que o protocolo descrito foi utilizado na amplificação do gene do $U$. urealyticum. Pode haver alteração no local de inserção dos "primers" que impediram a amplificação deste gene em alguns isolados.

Existem poucos dados na literatura quanto aos fatores ou características associadas à virulência de $U$. diversum. No presente estudo, foi observada, por meio de microscopia eletrônica, uma densa estrutura difusa e amorfa externamente a membrana citoplasmática das cepas e isolados de $U$. diversum. $O$ vermelho de ruteno utilizado liga-se especificamente com polissacarídeos e sugere a presença de estrutura similar ao glicocalix nos ureaplasmas estudados. Estudos anteriores com $U$. diversum falharam quanto ao uso da técnica de vermelho de ruteno, e esta estrutura não foi observada (ROBERTSON e SMOOK, 1976; HOWARD e GOURLAY, 1974).

Estruturas capsulares têm sido descritas em diversos micoplasmas, como M. meleagridis (GREEN e HANSON, 1973), M. mycoides subsp. mycoides SC, M. dispar (HOWARD e GOURLAY, 1974), U. urealyticum (ROBERTSON e SMOOK, 1976), M. gallisepticum (TAJIMA et al., 1982), M. ovipneumoniae (NIANG et al., 1998) e M. hyopneumoniae (TAJIMA e YAGIHASHI, 1982). Estes estudos sugerem que esta estrutura pode estar associada com a adesão, atividade anti-fagocitária e com outros fatores de virulência semelhante às cápsulas de bactérias com parede celular.

Tajima et al. (1982) observaram maior densidade da estrutura capsular de $M$. gallisepticum inoculados em traquéia de aves, quando comparado ao cultivado em meio líquido. Isto pode ser justificado pela maior expressão de fatores relacionados a virulência dos microrganismos em condições in vivo que in vitro. Niang et al. (1998) observaram que expressão de material capsular produzido por $M$. ovipneumoniae facilita a adesão dos microrganismos ao epitélio ciliar.

O glicocalix presente nos molicutes pode estar relacionado ao escape destes microrganismos aos mecanismos de defesa do hospedeiro. Almeida et al. (1992) demonstraram que cepas de M. dispar que expressavam material capsular apresentavam maior resistência à fagocitose quando comparado a 
cepas mutantes. Almeida e Rosenbusch (1991) demonstraram que bezerros infectados com $M$. dispar produziram anticorpos nas secreções pulmonares, e que estes anticorpos foram capazes de reconhecer o material capsular produzido em cepas cultivadas in vitro. Estes resultados indicam que a produção de material capsular pelo microrganismo é similar quando estes são cultivados ou presentes no hospedeiro.

A constituição bioquímica do material extracelular observado em $U$. diversum não foi definida no presente estudo, mas sugere-se semelhança a outros molicutes. Na cápsula de M. mycoides subsp. mycoides, M. mycoides subsp. capri e $M$. dispar foram identificadas a presença de resíduos de galactose (BUTTERY, 1970), poliglucanos (JONES et al., 1965) e polímeros de ácido galacturônico (MINION e ROSENBUSCH, 1993), respectivamente. A relação da quantidade destas substâncias pode estar associada às características patogênicas do micoplasma. De acordo com Howard e Gourlay (1974), a quantidade de galactana na cápsula de cepas de M. mycoides subsp. mycoides SC pode estar diretamente relacionada com a virulência. Os polissacarídeos extracelulares produzidos pelas bactérias, em geral, estão diretamente relacionados com fatores de virulência, contribuindo com o mimetismo molecular à resposta imune, resistência ao sistema complemento $\mathrm{e}$ escape da fagocitose (COMSTOCK e KASPER, 2006).

No presente estudo, as cepas e isolados de $U$. diversum apresentaram atividade de fosfolipase $\mathrm{C}$ nos testes quantitativos e qualitativos. A fosfolipase $C$, detectada em diversas bactérias, é uma enzima considerada fator de virulência para a destruição celular (SCHMIEL e MILLER, 1999; JEPSON TITBALL, 2000) e foi detectada em molicutes como U. urealyticum e M. hominis (SHIBATA et al., 1995; SILVA e QUINN, 1987). Silva e Quinn (1986) associam as fosfolipases $A_{2}$ e $C$ ao processo de remodelamento dos fosfolipídeos de $U$. urealyticum e toxicidade no processo de produção da doença.

Um fator de virulência importante de $U$. diversum está diretamente relacionado a ação de fosfolipases. Este microrganismo promove distúrbio na produção de prostaglandina, necessária na implantação e manutenção da gestação (KIM et al., 1994). Provavelmente a atividade da potente fosfolipase $A_{2}$, resulta na significante diminuição na produção da prostaglandina $E_{2}$ e $F_{2 a}$ 
pelas células do endométrio, após infecção pelo $U$. diversum (LAMONT et al., 1990). A fosfolipase dos ureaplasmas pode liberar quantidades excessivas de ácido aracdônico, resultando na inibição dos substratos para a síntese da prostaglandina (CASSEL et al., 1993). A fosfolipase $C$ atua semelhantemente a fosfolipase $A$, produzida pelo $U$. diversum, no entanto, possui seu sítio de ligação em ponto diferente da molécula de fosfolipídio. A fosfolipase $C$ também favorece o processo de escape do vacúolo, permitindo o acesso destas bactérias ao citoplasma (MEYER et al., 1997). Listeria monocytogenes deficientes em fosfolipase $\mathrm{C}$ mostrou-se menos virulenta que a amostra com esta enzima, quando inoculada em ratos (MARQUIS et al., 1995).

As IgA proteases bacterianas são um grupo de enzimas proteolíticas que clivam a imunoglobulina A, sendo sua primeira descrição em 1973 (MEHTA et al., 1973). Esta enzima apresenta-se como um fator de virulência, pois favorece a colonização bacteriana nas superfícies mucosas (MISTRY e STOCKLEY, 2006). A precisa função das IgA proteases é incerta, no entanto, acredita-se estar associada ao mecanismo de escape do sistema imune hospedeiro (VITOVSKI et al., 2002), que resulta na proteção das mucosas contra agentes infecciosos. Entre os molicutes, esta atividade tem sido bastante caracterizada em ureaplasmas de origem humana (ROBERTSON et al., 1984; KILIAN et al., 1984; SPOONER et al., 1992), no entanto, nos ureaplasmas bovinos não foi possível detectá-la.

A adesão e invasão são fatores de virulência pouco estudados nos molicutes de origem animal, mas conhecidos nas espécies de origem humana de maior importância. A adesão é considerada fator crucial na patogenicidade dos microrganismos e considerada um evento anterior à invasão. A invasão em células fagocíticas e não-fagocíticas tem sido descrita em diversos microrganismos e pode justificar, em parte, a cronicidade e recorrência de algumas infecções, bem como, o escape ao sistema imune e antibioticoterapias (ROTTEM, 2003).

A microscopia confocal utilizada no presente estudo mostrou-se um procedimento eficiente para a detecção de micoplasmas no interior de células não-fagocitárias, previamente infectadas com estes microrganismos. Foi possível observar a presença de ureaplasmas no espaço citoplasmático das 
células Hep-2, sendo sua intracelularidade confirmada pelo teste da gentamicina.

A invasão de células HeLa por M. penetrans pôde ser detectada com 20 min de infecção (BOROVSKY et al., 1998), e em células Hep-2, com 2 h pós infecção (BASEMAN e TULLY, 1997). O mesmo tempo de invasão (20 min) foi observado na infecção de $M$. genitalium em células HeLa, sendo o microrganismo visualizado no interior da célula por até 7 dias (DALLO e BASEMAN, 2000). Winner et al. (2000) observaram que a penetração de $M$. gallisepticum em células HeLa-229 e CEF ocorreu com cinco minutos de infecção e a concentração destes microrganismos aumentou com duas horas. Vancini e Benchimol (2008) detectaram a invasão de M. hominis em Trichomonas vaginalis, facilitando o seu escape da vacuolização, permanecendo no citosol celular. Esta internalização foi determinada pela combinação da microscopia confocal e teste da gentamicina, sendo estes testes amplamente utilizados para a determinação de invasão em micoplasmas.

Até o momento, não havia descrição na literatura da capacidade de internalização do $U$. diversum em linhagens celulares. A taxa de invasão, estudada pelo teste da gentamicina, foi maior nos isolados clínicos quando comparadas às das cepas ATCC. Os isolados de $U$. diversum de baixa e alta passagem apresentaram taxas de invasão similares no teste de gentamicina, não concordando com outros estudos, onde micoplasmas de alta passagem foram menos virulentos do que os de baixa passagem, quando inoculados em animais ou culturas celulares (WINNER et al. 2000; MUCH et al., 2002). Normalmente, as cepas de alta passagem são mais adaptadas ao crescimento em condições axigênicas, contrastando com as cepas de baixa passagem, que se mostram mais agressivas em infecções experimentais (VOGL et al., 2007). As cepas de M. gallisepticum de baixa passagem apresentaram maiores taxas de invasão em eritrócitos, células HeLa-229 e CEF do que as cepas de alta passagem (WINNER et al. 2000; VOGL et al., 2007). Os autores sugerem a que o cultivo freqüente dos molicutes em meios de cultura, pode induzir a perda ou inativação de informações genéticas, que por sua vez, podem estar associadas ao processo de invasão. 
Buim (2005) observou que cepas de alta (WVU 1853) e baixa passagem (MS1 e MS2) de M. synoviae apresentaram características similares de adesão e invasão em células Hep-2, com presença na região perinuclear. Ueno et al. (2008) observaram resultados semelhantes na invasão com cepas de $M$. genitallium infectando células HeLa e endometrial humana.

As características de invasão dos isolados e cepas ATCC de U. diversum em células Hep-2 indicam a localização perinuclear destes microrganismos após três horas de infecção, não sendo observadas diferenças entre amostras de alta ou baixa passagem. No presente estudo, a delimitação da lamina nuclear pela microscopia confocal foi importante para determinar a presença dos microrganismos na região perinuclear e a não invasão no espaço intranuclear. A disposição perinuclear de molicutes foi observada em diferentes espécies (BUIM, 2005; WINNER et al., 2000; YAVLOVICH et al., 2004a; BASEMAN et al., 1995). No entanto, Ueno et al. (2008) detectou M. genitalium no interior do núcleo após 30 min de infecção. Meseguer et al. (2003) também observou fluorescência na área nuclear, mas não pôde confirmar a presença de M. pneumoniae nesta região.

A invasão dos molicutes no citoplasma de células está sendo determinada em diversas espécies da Classe Mollicutes, porém mecanismos de invasão ainda não estão totalmente definidos. A ativação de plasminogênio favorece a invasão de $M$. fermentans, sugerindo a participação deste composto como fator na invasão celular desta bactéria durante a infecção (YAVLOVICH et al., 2001; 2004b). Além disto, acredita-se que a fosfolipase $C$ do ureaplasma pode estar associada a alterações na membrana e citoesqueleto da célula hospedeira, durante o processo de invasão (ROTTEM e NAOT, 1998; ANDREEV et al., 1995). Os molicutes, considerados capazes de invadir células não fagocitárias, geram sinais que desencadeiam alteração no citoesqueleto da célula hospedeira. A invasão de $M$. penetrans está associada com a fosforilação da tirosina, que ativa a fosfolipase $C$, gerando fosfatidilinositol e diacilglicerol (ANDREEV et al., 1995). Existem evidências que $M$. penetrans estimula a fosfolipase da célula hospedeira para clivar os fosfolipídeos da própria membrana, iniciando cascata de sinalização para o processo de invasão. O papel desta sequência para a penetração, sobrevivência e 
proliferação dos micoplasmas nas células hospedeiras, bem como 0 envolvimento dos lipídeos de membrana na patologia das células hospedeiras, são aspectos importantes a serem estudados (ROTTEM, 2003). As cepas de $U$. diversum, estudadas no teste de invasão, apresentaram alta atividade de fosfolipase C, não havendo diferenças entre as cepas de referências e os isolados clínicos. Desta maneira, esta enzima pode estar associada ao processo de invasão de $U$. diversum em células Hep-2.

As conseqüências biológicas dos fatores de virulência detectados nos ureaplasmas estudados não foram associadas às doenças nos bovinos. Much et al. (2002) observaram que cepas invasivas apresentaram-se mais virulentas comparadas às que não apresentavam capacidade de invasão. A importância da intracelularidade de $M$. synoviae em células Hep-2, detectada por Buim (2005), pode justificar as falhas no tratamento com antibióticos, a cronicidade das infecções e a persistência de planteis infectados por este microganismo por longos períodos. Diversos autores descrevem características semelhantes, de cronicidade e persistência, nas infecções causadas por $U$. diversum (MULIRA e SAUNDERS, 1994; RAE et al., 1993; TER LAAK et al., 1993). A evidência da internalização dos ureaplasmas nas células hospedeiras pode confirmar as características acima descritas.

A obtenção de informações sobre a atividade de fosfolipase $C$, presença de material extramembranoso polissacarídico e capacidade de invasão em células não-fagocíticas, do $U$. diversum, colaboram na compreensão da patogenicidade destes microrganismos, que podem orientar a preconização de terapias adequadas e desenvolvimento de imunoprofilaxia. A variabilidade genética, identificada nas cepas e isolados, indica a grande diversidade biológica destes microrganismos e a necessidade de aprimorar métodos de diagnósticos eficazes para as ureaplasmoses animais. 


\section{CONCLUSÕES}

- As cepas e isolados de $U$. diversum apresentaram polimorfismos $\mathrm{Na}$ sequencia parcial do gene $16 \mathrm{~S}$ rRNA;

- A análise de similaridade das seqüências parciais do gene $16 \mathrm{~S}$ rRNA permitiu o agrupamento das cepas e isolados em sete "clusters".

- Os "clusters" formados não permitiram a correlação da variação genotípica intraespecífica dos ureaplasmas isolados de animais sadios e doentes, bem como, com a presença dos fatores de virulência estudados;

- A análise de similaridade das sequencias do gene da urease nas cepas e isolados de $U$. diversum não foram realizadas devido a ausência de amplificação;

- As cepas e isolados de U. diversum, analisados por meio de microscopia eletrônica, apresentaram material polissacarídico extramembranoso;

- A atividade da fosfolipase $\mathrm{C}$ identificada nas cepas e isolados de $U$. diversum pode estar relacionada à virulência destes microrganismos, como descrito para outras bactérias;

- A capacidade de invasão de cepas e isolados de $U$. diversum em células Hep-2 foi evidenciada por meio de microscopia confocal, com localização no espaço citoplasmático e região perinuclear, e confirmada pelo teste da gentamicina;

- A capacidade de invasão das cepas e isolados de $U$. diversum pode estar relacionada a atividade da fosfolipase $\mathrm{C}$. 


\section{REFERÊNCIAS}

ALMEIDA, R. A.; ROSENBUSCH, R. F. Capsulelike surface material of Mycoplasma dispar induced by in vitro growth in culture with bovine cells is antigenically related to similar structures expressed in vivo. Infect. Immun., v. 59, n. 9, p. 3119-3125, 1991.

ALMEIDA, R.; WANNEMUEHLER, M.; ROSENBUSCH, R. Interaction of Mycoplasma dispar with bovine alveolar macrophages. Infect. Immun., v. 60, p. 2914-2919, 1992.

AMIKAM D.; GLASER, G.; RAZIN, S. Mycoplasmas (Mollicutes) have a low number of rRNA genes. J. Bacteriol., v. 158, p. 376-378, 1984.

ANDREEV, J.; BOROVSKY, Z.; ROSENSHINE, I.; ROTTEM, S. Invasion of HeLa cells by Mycoplasma penetrans and induction of tyrosine phosphorylation of a 145 kda host cell protein. FEMS Microbiol. Lett., v. 132, p. 189-194, 1995.

ANDREWS, A. H. Calf Respiratory Disease. In: ANDREWS, A. H.; BLOWEY, R. W.; BOYD, H.; EDDY, R. G (Eds.). Bovine medicine: diseases and husbandry of cattle. Germany: Backell Scientific, 1992. p. 202-212.

ARMSTRONG, C. H. Porcine Mycoplasmas. In: WHITFORD, H. W.; ROSENBUSCH, R. F.; LAUERMAN, L. H. (Ed.). Mycoplasmosis in Animals: Laboratory Diagnosis. lowa: lowa State University Press, Ames, 1994. p. 69-80.

BALISH, M. F.; KRAUSE, D. C. Cytadherence and the cytoskeleton. In: RAZIN, S.; ERRMANN, R. (Ed.). Molecular biology and pathogenicity of mycoplasmas. New York: Kluwer Academic, 2002. p. 73-90.

BALL, H. J.; MACKIE, D. P. The ovine mammary gland as in experimental model to determine the virulence of animal ureaplasmas. J. Hyg. Camb., v. 95, p. 375-382, 1985.

BALL, H. J.; LOGAN, E. F.; ORR, W. Isolation of mycoplasma from bovine semen in Northern Ireland. Vet. Rec., v. 121, p. 322-324, 1987.

\footnotetext{
De acordo com:

ASSOCIAÇÃO BRASILEIRA DE NORMAS TÉCNICAS. NBR 6023: Informação e documentação: referências: elaboração. Rio de Janeiro, 2002.
} 
BASEMAN, J. B.; LANGE, M.; CRISCIMAGNA, N. L.; GIRON, J. A. THOMAS, C. A. Interplay between mycoplasmas and host target cells. Microb. Pathog., v. 19, p. 105-116, 1995.

BASEMAN, J. B.; TULLY, J. G. Mycoplasmas: sophisticated, reemerging, and burdened by their notoriety. Emerg. Infect. Dis., v. 3, p. 21-32, 1997.

BÉBÉAR, C. M.; AULLO, P.; BOVE, J. M.; RENAUDIN, J. Spiroplasma citri virus $\mathrm{SpV} 1$ : characterization of viral sequences present in the spiroplasmal host chromosome. Curr. Microbiol., v. 32, p. 134-140, 1996.

BENSON, D. A.; KARSCH-MIZRACHI, I.; LIPMAN, D. J.; OSTELL, J.; SAYERS, E. W. GenBank. Nucleic Acids Res., v. 37, p. 26-31, 2009.

BERGEY'S Manual of determinative bacteriology. Michigan: Michigan State University, 2001. Disponível em: <http://www.cme.msu.edu/bergeys>. Acesso em: 14 Mar. 2005.

BOATMAN, E. S.; CARTWIRIGHT, F.; KENNY, G. Morphology and ultrastructure of mycoplasmatale. In: BARILE, F. M.; RAZIN, S. (Ed.) The Mycoplasmas. London: Academic Press, 1979. v. 1, p. 63-101.

BOOM, R.; SOL, C. J.; SALIMANS, M. M.; JANSEN, C. L.; WERTHEIM-VAN DILLEN, P. M.; VAN DER NOORDAA, J. Rapid and simple method for purification of nucleic acids. J. Clin. Microbiol., v. 28, n. 3, p. 495-503, 1990.

BOROVSKY, Z.; TARSHIS, M.; ZHANG, A.; ROTTEM, S. Mycoplasma penetrans invasion of HeLa cells induces protein kinase $\mathrm{C}$ activation and vacuolation in the host cells. J. Med. Microbiol., v. 47, p. 915-922, 1998.

BRITTON, A. P.; MILLER, R. B.; RUHNKE, H. L.; JOHNSON, W. M. Protein A Gold identification of Ureaplasmas on the bovine zona pellucida. Can. J. Vet. Res., v. 53, p. 172-175, 1989.

BRITTON, A. P.; MILLER, R. B.; RUHNKE, H. L.; JOHNSON, W. M. The recovery of Ureaplasmas from bovine embrios following in vitro exposure and ten washes. Theriogenology, v. 30, p. 997-1003, 1988. 
BRITTON, A. P.; RUHNKE, H. L.; MILLER, R. B.; JOHSON, W. H.; LESLIE, K. E.; ROSENDAL, S. In vitro exposure of bovine morulae to Ureaplasma diversum. Can. J. Vet. Res., v. 51, p. 198-203, 1987.

BROWN, D. R.; ZACHER, L. A.; CARBONNEAU, D. A. Seroprevalence of Mycoplasma alligatoris among free-ranging alligators (Alligator mississippiensis) in Florida - 2003. J. Zoo Wildl. Med., v. 36, n. 2, p. 340-341, 2005.

BUIM, M. R.; BUZINHANI, M.; YAMAGUTI, M.; OLIVEIRA, R. C.; METTIFOGO, E.; TIMENETSKY, J.; FERREIRA, A. J. Intraspecific variation in 16S rRNA gene of Mycoplasma synoviae determined by DNA sequencing. Comp. Immunol. Microbiol Infect. Dis. In press.

BUIM, M. R. Mycoplasma synoviae: diagnóstico, caracterização molecular e interação parasita-hospedeiro. 133 f. Tese (Doutorado em Microbiologia) Instituto de Ciências Biomédicas, Universidade de São Paulo, São Paulo, 2005.

BUTTERY, S. H. Hapten inhibition of the reaction between Mycoplasma mycoides polysaccharide and bovine antisera. Immunochemistry, v. 7, p. 305310, 1970.

BUZINHANI, M.; BUIM, M. R.; YAMAGUTI, M.; OLIVEIRA, R. C.; METTIFOGO, E.; TIMENETSKY, J. Genotyping of Ureaplasma diversum isolates using pulsed-field electrophoresis. Vet. J., v. 173, n. 3, p. 688-690, 2007 a.

BUZINHANI, M.; METTIFOGO, E.; BUIM, M. R.; MORENO, A. M.; PAIXÃO, R.; TIMENETSKY, J. Isolates of Ureaplasma diversum genotyped by singleenzyme amplified length polymorphism. Braz. J. Microbiol., v. 38, n. 1, p. 2832, 2007b.

BUZINHANI, M.; METTIFOGO, E.; TIMENETSKY, J. Detecção de Mycoplasma spp. e Ureaplasma diversum em vacas com distúrbios reprodutivos. Arq. Bras. Med. Vet. Zootec., v.59, n.6, p.1368-1375, 2007c.

BUZINHANI, M. Identificação sorológica e diversidade genotípica das estirpes de Ureaplasma diversum isoladas do trato reprodutivo bovino. 2006. 152 f. Tese (Doutorado em Microbiologia) - Instituto de Ciências Biomédicas, Universidade de São Paulo, São Paulo, 2006.

CARDOSO, M. V.; SCARCELLI, E.; GRASSO, L. M. P. S.; TEIXEIRA, S. R.; GENOVEZ, M. E. Ureaplasma diversum and reproductive disorder in Brazilian caws and heifers; first report.. Anim. Reprod. Sci., v. 63, p. 137-143, 2000. 
CARSON, J. L.; HU, P. C.; COLLIER, A. M. Cell structural and functional elements. In: MANILOFF J.; MCELHANEY, R. N.; FINCH L. R.; BASEMAN J. B. (Ed.). Mycoplasmas: molecular biology and pathogenesis. Washington: American Society for Microbiology, 1992. p. 63-72.

CASSEL, G. H.; WAITS, K. B.; WATSON, H. L.; CROUSE, D. T.; HARASAWA, R. Ureaplasma urealyticum: role in prematury and disease in newborns. Clin. Microbiol. Rev., v. 6, 69-87, 1993.

CHELMOŃSKA-SOYTA, A.; KATSKA, L.; KURPISZ, M.; STEFANIAK, T.; ZIMECKI, M. The effect of Ureaplasma diversum activated mononuclear leukocytes on the development and interferon-tau production by bovine IVFderived embryos. J. Reprod. Immunol., v. 51, n. 2, p. 145-158, 2001.

CHELMONSKA-SOYTA, A.; MILLER, R. B.; RUHNKE, L.; ROSENDAL, S. Activation of murine macrophages and lymphocytes by Ureaplasma diversum. Can. J. Vet. Res., v. 58, n. 4, p. 275-80, 1994.

CHERNOV, V. M.; VOLKOVA, E. N.; CHERNOVA, O. A. Clastogenic effect of mycoplasma on human chromosomes. Dokl. Akad. Nauk., v. 344, n. 1, p. 130132, 1995.

CILIA, V.; LAFAY, B.; CHRISTEN, R. Sequence heterogeneities among $16 \mathrm{~S}$ ribosomal RNA sequences, and their effect on phylogenetic analyses at the species level. Mol. Biol. Evol., v. 13, p. 451-461,1996.

COMSTOCK, L. E.; KASPER, D. E. Bacterial glycans: key mediators of diverse host immune responses. Cell, v. 126, p. 847-850, 2006.

CUNHA, R. A.; KOIFFMAN, C. P.; SOUZA, D. H.; TAKEI, K. Clastogenic effects of different Ureaplasma urealyticum serovars on human chromosomes. Braz. J. Med. Biol. Res., v. 30, n. 6, p. 749-757, 1997.

DALLO, S. F.; BASEMAN, J. B. Intracellular DNA replication and long-term survival of pathogenic mycoplasmas. Microb. Pathog., v. 29, n. 5, p. 301-309, 2000.

DALLO, S. F.; BASEMAN, J. B. Cross-hybridization between the cytadhesin genes of Mycoplasma pneumoniae and Mycoplasma genitalium and genomic DNA of Mycoplasma gallisepticum. Microb. Pathog., v. 8, p. 371-375, 1990a. 
DALLO, S. F.; CHAVOYA, A.; BASEMAN, J. B. Characterization of the gene for a $30-\mathrm{kDa}$ adhesion-related protein of Mycoplasma pneumoniae. Infect. Immun., v. 58: p. 4163-4165, 1990b.

DAVID, Y.; BROWNING, G.F.; WISE, K.S. Genetic mechanisms of surface variation. In: RAZIN, S.; HERRMANN, R. (Ed.). Molecular Biology and Pathogenicity of Mycoplasmas. New York, USA: Kluwer Academic, 2002. p. 417-443.

DAVIDSON, M. K.; DAVIS, J. K.; GAMBILL, G. P.; CASSEL, G. H.; LINDSEY, J. R. Mycoplasmas of Laboratory Rodents. In: WHITFORD, H. W., ROSENBUSCH, R. F, LAUERMAN, L. H. (Ed.). Mycoplasmosis in Animals: Laboratory Diagnosis. lowa: lowa State University Press, 1994. p. 97-124.

DELGIUDICE, R. A.; CARSKI, T. R.; BARILE, M. F.; LEMCKE, R. M.; TULLY, J. G. Proposal for Classifying Human Strain Navel and Related Simian Mycoplasmas as Mycoplasma primatum sp. J. Bacteriol., v. 108, n. 1, p. 439445, 1971.

DOIG, P. A. Bovine genital mycoplasmosis. Can. Vet. J., v. 22, p. 339-343, 1981.

DOIG, P. A.; RUHNKE, H. L.; MACKAY, A. L. ET AL. Bovine granular vulvitis associated with ureaplasmas infection. Can. Vet. J., v. 20, p. 89-94, 1979.

DOIG, P. A.; RUHNKE, H. L.; MILLER, R. B. Bovine reproductive failure associated with Ureaplasma diversum. Proc. Am. Assoc. Bovine Prat., v. 16, p. 155-158, 1984.

DOIG, P. A.; RUHNKE, H. L.; PALMER, N. C. Experimental bovine genital ureaplasmosis: I. Granular vulvitis following vulvar inoculation. Can. J. Comp. Med., v. 44, p. 252-258, 1980a.

DOIG, P. A.; RUHNKE, H. L.; PALMER, N. C. Experimental bovine genital ureaplasmosis: II. Granular vulvitis, endometriti and salpingites following uterine inoculation. Can. J. Comp. Med., v. 44, p. 259-266, 1980 b.

DYBVIG, K.; VOELKER, L. L. Molecular biology of mycoplasmas. Annu. Rev. Microbiol., v. 50, p. 25-27, 1996. 
DYBVIG, K.; HOLLINGSHEAD, S. K.; HEATH, D. G.; CLEWELL, D. B.; SUN, F.; WOODARD, A. Degenerate oligonucleotide primers for enzymatic amplification of recA sequences from gram-positive bacteria and mycoplasmas.

J. Bacteriol., v. 174, n. 8, p. 2729-2732, 1992.

EAGLESOME, M. D.; GARCIA, M. M.; STEWART, R. B. Microbial agents associated with bovine genital tract infections and semen. Part II. Haemophilus sommus, Mycoplasma spp. and Ureaplasmas spp., Chlamydia; Phathogens and semen contaminants; treatment of bull semen with antimicrobial agents. Vet. Bull., v. 62, p. 887-910, 1992.

ERA, D. O.; CHENOWETH, P. J.; BROWN, M. B. Ureaplasma infection on the bovine. Arch. STD/HIV Res., v. 7, p. 239-243, 1995.

FADIEL, A.; EICHENBAUM, K. D.; EL SEMARY, N.; EPPERSON B. Mycoplasma genomics: tailoring the genome for minimal life requirements through reductive evolution. Front. Biosci., v. 12, p. 2020-2028, 2007.

FISH, NA. A.; ROSENDAL, S.; MILLER, R. B. The distribution of Mycoplasmas and Ureaplasmas in the genital tract of normal artificial insemination bulls. Can. Vet. J., v. 26, p. 13-15, 1985.

FREY, J. Mycoplasmas of animals. In: RAZIN, S.; HERRMANN, R. (Ed.). Molecular biology and pathogenicity of mycoplasmas. New York: Kluwer Academic, 2002. p. 73-90.

GADEAU, A. P.; MOUCHES, C.; BOVE, J. M. Probable insensitivity of mollicutes to rifampin and characterization of spiroplasmal DNA-dependent RNA polymerase. J Bacteriol., v. 166, n. 3, p. 824-828, 1986.

GAGEA, M. I.; BATEMAN, K. G.; VAN DREUMEL, T.; MCEWEN, B. J.; CARMAN, S.; ARCHAMBAULT, M.; SHANAHAN, R. A.; CASWELL, J. L. Diseases and pathogens associated with mortality in Ontario beef feedlots. J. Vet. Diagn. Invest., v. 18, n. 1, p. 18-28, 2006.

GARCIA, M.; JACKWOOD, M. W.; HEAD, M.; LEVISOHN, S.; KLEVEN, S. H. Use of speceies-specific oligonucleotide probes to detect Micoplasma gallisepticum, M. synoviae, and $M$. iowae PCR amplication products. J. Vet. Diag. Invest., v. 8, p. 53-56, 1996. 
GARDELLA, R. S.; DEL GIUDICE, R. A. Optimal temperature and atmospheric conditions for growth. In: RAZIN, S.; TULLY, J. G. (Ed.). Methods in Mycoplasmology. New York: Academic Press, 1983. v. 1, p. 211-218.

GLASS, J. I.; LEFKOWITZ, E. J.; GLASS, J. S.; HEINER, C. R.; CHEN, E. Y.; CASSELL, G. H. The complete sequence of the mucosal pathogen Ureaplasma urealyticum. Nature, v. 407, n. 6805, p. 757-762, 2000.

GREEN, F.; HANSON, R. P. Ultrastructure and capsule of Mycoplasma meleagridis. J. Bacteriol., v. 116, p. 1011-1018, 1973.

HARASAWA, R.; CASSELL, G. H. Phylogenetic analysis of genes coding for $16 \mathrm{~S}$ rRNA in mammalian ureaplasmas. Int. J. Syst. Bacteriol., v. 46, n. 3, p. 827-829, 1996.

HARASAWA, R.; LEFKOWITZ, E. J.; GLASS, J. I.; CASSELL, G. H. Phylogenetic analysis of the 16S-23S rRNA intergenic spacer regions of the genus Ureaplasma.

J. Vet. Med. Sci., v. 58, n. 3, p. 191-195, 1996.

HELDTANDER, M.; PETTERSSON, B.; TULLY, J. G.; JOHANSSON, K. E. Sequences of the 16S rRNA genes and phylogeny of the goat mycoplasmas; Mycoplasma adleri, Mycoplasma auris, Mycoplasma cottewii and Mycoplasma yeatsii. Int. J. Syst. Bacteriol., v. 48, p. 263-268, 1998.

HERDTANDER, M.; WESONGA, H.; BÖLSKE, G.; PETTERSSON, B.; JOHANSSON, K. E. Genetic diversity and evolution of Mycoplasma capricolum subsp. Capripneumoniae strain from Eastern Africa assessed by $16 \mathrm{~S}$ rDNA sequence analysis. Vet. Microbiol., v. 78, p. 13-28, 2001.

HEREMANN, R. Genome structure and organization. In: MANILOFF, J. McELHANEY, R. N.; FINCH, L. R.; BASEMAN, J. B. (Ed.). Molecular biology and pathogenesis. Washigton: American Society of Microbiology, 1992. $p$. 157.

HILL, C. W.; HARNISH, B. W. Inversions between ribosomal RNA genes of Escherichia coli. Proc. Natl. Acad. Sci., v. 78, n. 11, p. 7069-7072, 1981.

HOERR, F.J.; LOCKABY, S.B.; BICKFORD, A. A.. Pathology of mycoplasmosis. In: Poultry mycoplasma workshop-histopathology. California: American College of Poultry, 1994. p. 1-12. 
HOWARD, C.J.; POCOCK, D.H. Comparison of Ureaplasmas from sheep and goats with Ureaplasma diversum and U. urealyticum. J. Gen. Microbiol., v. 129, p. 3197-3202, 1983.

HOWARD, C. J.; GOURLAY, R. N. An electron microscopic examination of certain bovine mycoplasmas stained with ruthenium red and the demonstration of a capsule on Mvcoplasma dispar. J. Gen. Microbiol., v. 83, p. 393-398, 1974.

HOWARD, C. J.; GOURLAY, R. N. Identification of ureaplasmas from cattle using antisera prepared in gnotobiotic calves. J. Gen. Microbiol., v. 126, n. 2, p. 365-369, 1981.

HOWARD, C. J.; GOURLAY, R. N.; THOMAS, L. H.; STOTT, E. J. Induction of pneumonia in gnotobiotic calves following inoculation of Mycoplasma dispar and ureaplasmas (T-mycoplasmas). Res. Vet. Sci., v. 21, n. 2, p. 227-31, 1976.

HOWARD, C. J.; GOURLAY, R. N.; COLLINS, J. Serological comparison between twenty-five bovine Ureaplasma (T-mycoplasma) strain by immunofluorescense. Int. J. Bacteriol., v. 25, p. 155-159, 1976.

HOWARD, C. J.; GOURLAY, R. N.; BROWNLIE, J. The virulence of Tmycoplasmas isolated from various animal species, assayed by intramammary inocutation in cattle. J. Hyg. Camb., v. 71, p. 163-170, 1973.

HOWARD, C, J.; GOURLAY, R. N.; COLLINS, J.. Serological studies with bovine ureaolasmas (T-mycoplasmas). Int. J. Syst. Bacteriol., v. 28, p. 473477, 1978.

IDE, P. R. Developments in veterinary science: the etiology of enzootic pneumonia of calves. Can. Vet. J., v. 11, n. 10, p.194-202, 1970.

INAMINE, J. M.; LOECHEL, S.; COLLIER, A. M.; BARILE, M. R.; HU, P. C. Nucleotide sequence of the $\mathrm{MgPa}$ (mgp) operon of Mycoplasma genitalium and comparison to the P1 (mpp) operon of Mycoplasma pneumoniae. Gene, v. 82, p. 259-267, 1989.

JASPER, D. E. Mycoplasma: their role in bovine disease. J. Am. Vet. Med. Assoc., v. 151, p. 1650-1655, 1967.

JEPSON, M.; TITBALL, R. Structure and function of clostridial phospholipases C. Microbes Infect., v. 2, n. 10, p. 1277-1284, 2000. 
JONES, A. S.; TITTENSOR, J. R.; WALKER, R. T. The chemical composition of the nucleic acids and other macromolecular constituents of Mycoplasma mycoides var. capri. J. Gen. Microbiol., v. 40, n. 3, p. 405-411, 1965.

KAPATAIS-ZOUMBOS, K.; CHANDLER, D. K.; BARILE, M. F. Survey of immunoglobulin A protease activity among selected species of Ureaplasma and Mycoplasma: specificity for host immunoglobulin A. Infect. Immun., v. 47, n.3, p. 704-9, 1985.

KILIAN, M.; BROWN, M. B.; BROWN, T. A.; FREUNDT, E. A.; CASSELL, G. H. Immunoglobulin A1 protease activity in strains of Ureaplasma urealyticum. Acta Pathol. Microbiol. Immunol. Scand. B, v. 92, n. 1, p.61-64, 1984.

KIM, J. J.; QUINN, P. A.; FOERTIER, M. A. Ureaplasma diversum infection in vitro alters prostaglandin $E_{2}$ and prostaglandin $F_{2 a}$ production by bovine endometrial cells without affecting cell viability. Infect. Immun., v. 62, p. 15281533, 1994.

KIRKBRIDE, C. A. Mycoplasma, Ureaplasma, and Acholeplasma infections of bovine genitalia. Vet. Clin. North Am. Food Anim. Prac., v. 3, p. 575-591, 1987.

KNOX, C. L.; GIFFARD, P.; TIMMS, P. The phylogeny of Ureaplasma urealyticum based on the mba gene fragment. Int. J. Syst. Bacteriol., v. 48, p. 1323-1331, 1998.

KÖNIGSSON, M. H.; BÖLSKE G.; JOHANSSON, K. E. Intraspecific variation in the 16S rRNA gene sequences of Mycoplasma agalactiae and Mycoplasma bovis strains. Vet. Microbiol., v. 85, p. 209-220, 2002.

KOTANI, H.; NAGATOMO, H.; OGATA, M. Isolation and serological comparison of ureaplasmas from goats and sheep. Jpn. J. Vet., v. 42, p. 31-40, 1980.

KREPLIN, C. M.; RUHNKE, H. L.; MILLER, R. B.; DOIG, P. A. The effect of intrauterine inoculation with Ureaplasma diversum on bovine fertility. Can. J. Vet. Res., v. 51, n. 4, p. 440-443, 1987.

LAMONT, R. F.; ANTHONY, F.; MYATT, L.; BOOTH, L.; FURR, P. M.; TAYLOR-ROBINSON, D. Production of prostaglandin E2 by human amnion in vitro in response to addition of media conditioned by microorganism associated 
with chorioamnionitis and preterm labor. Am. J. Obstet. Gynecol., v. 162, p. 819-825, 1990.

LE GRAND, D.; POUMARAT, F.; MARTEL, J. L. Infectious genital disease by Ureaplasma diversum, investgations on bovine in France. Vet. Res., v. 26, n. 1, p. 11-20, 1995.

LEACH, R.H. The osmotic requirements for growth of mycoplasmas. J. Gen. Microbiol., v. 27, p. 345-354, 1962.

LEÓN, B. A.; CAMPOS, E.; BOLAÑOS, H.; CABALLERO, M. Risk factors for Ureaplasma diversum infections in cattle of a tropical environment. Rev. Biol. Trop., v. 43, n. 1-3, p. 21-25, 1995.

LIVINGSTON, C. W.; GAUER, B.B.; SHELTON, M. A specific Ureaplasmal serotype associated with ovine uterine infections. Am. J. Vet. Res., v. 39, n. 10, p. 1699-1701, 1978.

LIVINGSTON, C. W.; GAUER, B.B. Effect of venereal transmission of ovine ureaplasma on reproductive efficiency of ewes. Am. J. Vet. Res., v. 43, n. 7, p. 1991-1993, 1982.

LO, S. C. Apoptotic, antiapoptotic, clastogenic and oncogenic effects. In: RAZIN, S.; HERRMANN, R. (Ed.). Molecular Biology and Pathogenicity of Mycoplasmas. New York, USA: Kluwer Academic, 2002. p. 403-416.

LOUGHNEY, K.; LUND, E.; DAHLBERG, J. E. tRNA genes are found between $16 \mathrm{~S}$ and $23 \mathrm{~S}$ rRNA genes in Bacillus subtilis. Nucleic Acids Res. v. 10, n. 5, p. 1607-1624, 1982.

MANILOFF, J. Phylogeny and evolution. In: RAZIN, S.; HERRMANN, R. (Ed.). Molecular biology and pathogenicity of mycoplasmas. New York: Kluwer Academic, 2002. p. 31-43.

MANILOFF, J. Phylogeny of mycoplasmas. In: MANILOFF, J.; McELHANEY, R.N.; FINCH, L.R.; BASEMAN, J.B. (Ed.). Mycoplasmas: molecular biology and pathogenesis. Washington: American Society for Mcrobiology, 1992. p. 549-559.

MANILOFF, J. Evolution of wall-less prokaryotes. Annu. Rev. Microbiol., v. 37, p. 477-499, 1983. 
MARQUES, L. M.; BUZINHANI, M.; OLIVEIRA, R. C.; YAMAGUTI, M.; FERREIRA, J. B.; NETO, R. L.; TIMENETSKY, J. Prevalence of mycoplasmas in the respiratory tracts of calves in Brazil. Vet. Rec., v. 161, n. 20, p. 699-700, 2007.

MARQUIS, H.; DOSHI, V.; PORTNOY, D. A. The broad-range phospholipase C and a metalloprotease mediate listeriolysin O-independent escape of Listeria monocytogenes from a primary vacuole in human epithelial cells. Infect. Immun., v. 63, n. 11, p. 4531-4534, 1995.

MAXIE, M. G. Etiologic agent or condition associated with abortion in cattle. Can. Vet. J., v. 27, p. 1983-1985, 1986.

MEHTA, S. K.; PLAUT, A. G.; CALVANICO, N. J. TOMASI JR., T. B. Human immunoglobulin $A$ : production of an Fc fragment by an enteric microbial proteolytic enzyme. J. Immunol., v. 111, n. 4, p.1274-1276, 1973.

MESEgueR, M. A.; ALVAREZ, A.; REJAS, M. T.; SÁNCHEZ, C.; PÉREZDÍAZ, J. C.; BAQUERO, F. Mycoplasma pneumoniae: a reduced-genome intracellular bacterial pathogen. Infect. Genet. Evol., v. 3, n.1, p. 47-55, 2003.

MEYER, D. H.; MINTZ, K. P.; FIVES-TAYLOR, P. M. Models of invasion of enteric and periodontal pathogens into epithelial cells: a comparative analysis. Crit. Rev. Oral Biol. Med., v. 8, n. 4, p. 389-409, 1997.

MILES, R.; NICHOLAS, R. Mycoplasma protocols: Introduction. Methods Mol. Biol., v. 104, p. 01-05, 1998.

MILES, R. J. Cell nitrition and growth. In: MANILOFF, J.; MCELHANEY, R. N.; FINCH, L. R.; BASEMAN, J. B. (Ed.). Mycoplasmas: molecular biology and pathogenesis. Washington: American Society for Microbiology, 1992. p. 23-40.

MILLER, R. B.; RUHNKE, H. L.; DOIG, P. A.; POITRAS, B. J.; PALMER, N. C. The effects of Ureaplasma diversum inoculated into the dynamic cavity in cows. Theriogenology, v. 20, p. 367-373, 1983.

MILLER, R. B.; CJELMONSKA-SOYTA, A.; SMITS, B.; FOSTER, R.; ROSENDAL, S. Ureaplasma diversum as a cause of reproductive disease in cattle. Vet. Clin. North Am. Food Anim. Prac., v. 10, p. 479-490, 1994. 
MINION, F. C.; ROSENBUSCH, R. F. Extramembranous structure in mycoplasmas. Subcell Biochem., v. 20, p. 189-201, 1993.

MISTRY, D.; STOCKLEY, R. A. IgA1 protease. Int. J. Biochem. Cell Biol., v. 38 , n. 8, p. 1244-1248, 2006.

MOHAMMED, H. O.; CARPERTER, T. E.; YAMAMOTO, R. Economic impact of Mycoplasma gallisepticum and Mycoplasma synoviae in commercial layer flocks. Avian Dis., v. 31, p. 477-482, 1987.

MOROWITZ, H. J. Foreword: from the enigmatic pleuropneumonia-like organisms to the paradigmatic mycoplasma. In: RAZIN, S.; HERRMANN, R. (Ed.). Molecular biology and pathogenicity of mycoplasmas. New York: Kluwer Academic/Plenum Publishers, 2002. p. 5-8.

MUCH, P.; WINNER, F.; STIPKOVITS, L.; ROSENGARTEN, R.; CITTI, C. Mycoplasma gallisepticum: Influence of cell invasiveness on the outcome of experimental infection in chickens. FEMS Immunol. Med. Microbiol., v. 34, n. 3, p. 181-186, 2002.

MUENSTER, O. A.; OSE, E. E.; MATSUOKA, T. The incidence of Mycoplasma dispar, Ureaplasma and conventional Mycoplasma in the pneumonic calf lung. Can. J. Comp. Med., v. 43, n. 4, p. 392-398, 1979.

MULIRA, G. L.; SAUNDERS, J. R. Immune response of heifers to vaginal submucosal or subcutaneous vaccination and intravaginal challenge with Ureaplasma diversum. Can. J. Vet. Res., v. 58, n. 2, p. 109-113, 1994.

MULIRA, G. L.; SAUNDERS, R.; ARTH, A. D. Isolation of Ureaplasma diversum and mycoplasma from genital traces of beef and dairy cattle in Saskatchewan. Can. Vet. J., v. 33, p. 46-49, 1992.

MUTO, A.; HORI, H.; SAWADA, M.; KAWAUCHI, Y.; IWAMI, M.; YAMAO, F.; OSAWA, S. The ribosomal genes of Mycoplasma capricolum. Yale J. Biol. Med., v. 56, n. 5-6, p. 373-376, 1983.

MYGIND, T; BIRKELUND, S.; CHRISTIANSEN, G. DNA sequencing reveals limited heterogeneity in the 16S rRNA gene from the $\mathrm{rrmB}$ operon among five Mycoplasma hominis isolates. Int. J. Syst. Bacteriol. v. 48, p. 1067-10781, 1998. 
NASCIMENTO, E. R.; NASCIMENTO, M. G. F.; FREUND, E. A.; ANDERSEN, $\mathrm{H}$. Isolation of Mycoplasmas mycoides from outbreaks of caprine mycoplasmosis in Brazil. Br. Vet. J., v. 142, p. 246-257, 1986.

NEIMARK, H. C. Origins and evolution of wall-less prokaryotes. In: MADOFF, S. (Ed.). The bacterial L-forms. New York: Marcel Dekker, 1986. p. 21-42.

NIANG, M.; ROSENBUSCH, R. F.; ANDREWS, J. J.; KAEBERLE. M. L. Demonstration of a capsule on Mycoplasma ovipneumoniae. Am. J. Vet. Res., v. 59, p. $557-562,1998$.

NICOLET, J. Compedio de bacteriologia veterinária. Zaragoza: Acribia, 1986. p. 275.

NICOLSON, G. L.; NASRALIA, M. Y.; NICOLSON, N. L. The pathogenesis and treatment of mycoplasma infection. Antimicrob. Infect. Dis. Newslet., v. 17, n. 11, p. $81-88,1999$.

NOCARD, E.; ROUX, E. R. Le microbe de la pleuropneumoniae. Ann. Inst. Pasteur, v. 12, p. 240-262, 1898.

OGATA, M.; KOTANI, H.; YAMAMOTO, K. Serological comparison of bovine ureaplasmas. Nippon Juigaku. Zasshi., v. 41, n. 6, p. 629-637, 1979.

OLSON, L. D.; RENSHAW, C. A.; ROTTEM, S.; BOAL, J. H. Arginine utilization by Mycoplasma fermentans is not regulated by glucose metabolismo ${ }^{13} \mathrm{C}-\mathrm{NMR}$ study. FEMS Microbiol. Lett., v. 108, n. 47-52, 1993.

PADDENBERG, R.; WULF, S.; WEBER, A.; HEIMANN, P.; BECK, L. A.; MANNHERZ, H. G. Internucleosomal DNA fragmentation in cultured cells under conditions reported to induce apoptosis may be caused by mycoplasma endonucleases. Eur. J. Cell. Biol., v. 71, n. 1, p. 105-119, 1996.

PANANGALA, V. S.; WINTER, A. J.; WIJESINHA, A.; FOOTE, R. H. Decreased motility of bull spermatozoa caused by Mycoplasma bovigenitalium. Am. J. Vet. Res., v. 42, n. 12, p. 2090-2093, 1981.

PETIT, T.; SPERGSER, J.; AURICH, J.; ROSENGARTEN, R. Prevalence of Chlamydiaceae and Mollicutes on the genital mucosa and serological findings in dairy cattle. Vet. Microbiol., v. 127, n. 3-4, p. 325-333, 2008. 
PETTERSSON, B.; BÖLSKE, G.; THIAUCOURT, F.; UHLÉN, M.; JOHANSSON, K. Molecular evolution of Mycoplasma capricolum subsp. capripneumoniae strains, based on polymorphisms in the 16S rRNA genes. J. Bacteriol., v. 180, p. 2350-2358, 1998.

PETTERSSON, B.; JOHANSSON, K. E.; UHLÉN, M. Sequence analysis of $16 \mathrm{~S}$ rRNA from Mycoplasma by direct solid-phase DNA sequencing. Appl. Environ. Microbiol., v. 60, p. 2456-2461, 1994.

PETTERSSON, B.; UHLÉN, M.; JOHANSSON, K. E. Phylogeny of some Mycoplasma from ruminats based on 16S rRNA sequences and definition of a new cluster within the hominis group. Int. J. Syst. Bacteriol., v. 46, p. 10931098, 1996.

PETTERSSON, S.; SHARPE, M. J.; GILMORE, D. R.; SURANI, M. A.; NEUBERGER, M. S. Cellular selection leads to age-dependent and reversible down-regulation of transgenic immunoglobulin light chain genes. Int. Immunol., v. 1, n. 5, p. 509-516, 1989.

PILAZEC, J.; TRUSZCYNSKI, M. Affinity of microorganisms of the genus Ureaplasma to the reproductive organs of cattle. Comp. Immunol. Micorbiol. Infec. Dis., v. 11, p. 177-180, 1988.

RADOTITS, O. M. Doenças bacterianas. In: RADOTITS, O (Ed.). Clínica veterinária: um tratado de doenças dos bovinos, ovinos, suínos, caprinos e eqüinos. Rio de Janeiro: Guanabara Koogan, 2002. p. 896-915.

RAE, D. O.; CHENOWETH, P. J.; BROWN, M. B.; GENHO, P. C.; MOORE, S. A.; JACOBSEN, K. E. Reproductive performance of beef heifers: Effects of vulvo-vaginitis, Ureaplasma diversum and prebreeding antibiotic administration. Theriogenology, v. 40, n.3, p. 497-508, 1993.

RAZIN, S.; BARILE, M.F. Mycoplasma pathogenicity. In: RAZIN, S.; BARILE, M.F. (Ed.). The mycoplasmas. Orlando: Academic Press, 1985.

RAZIN, S.; JACOBS, E. Mycoplasma adhesion. J. Gen. Microbiol., v. 138, p. 407-422, 1992.

RAZIN, S.; TULLY, J. G. Methods in Mycoplasmology: Mycoplasmas Characterization. New York: Academic Press, 1983. v.1, 54 p. 
RAZIN, S.; MASOVER, G. K.; PALANT, M.; HAYFLICK, L. Morphology of Ureaplasma urealiticum (T-mycoplasma) organisms and colonies. J. Bacteriol., v. 130 , p. $464-471,1977$.

RAZIN, S.; YOGEV, D.; NAOT, Y. Molecular biology and pathogenicity of Mycoplasma. Microbiol. Mol. Biol. Rev., p. 1094-1156, 1998.

RAZIN, S. The mycoplasmas. Microbiol. Rev., v. 42, p. 414-470, 1978.

RAZIN, S. Molecular properties of Mollicutes: A synopsis. In: RAZIN, S. TULLY, J. G. (Ed.). Molecular and Diagnostic procedures in Mycoplasmology. San Diego: Academic Press, 1995. v. 1, p. 1-25.

RAZIN, S. Mycoplasma Taxonomy and Ecology. In: Maniloff, J.; McElhaney, R. N.; Finch, L. R.; Baseman, J. B. Mycoplasmas Molecular Biology and Pathogenesis. Washington: American Society For Microbiology, 1992. p. 322.

RAZIN, S. Mycoplasmas: General concepts. Medical Microbiology, 2004. Disponível em: <http://gsbs.utmb.edu/microbook/ch037.htm>. Acesso em 14 Mar. 2005.

REBHUN, W. C.; GUARD, C.; RICHARDS, C. M. Doenças respiratórias. In: Rebbun, W. C.; Guard, C.; Richards, C. M. Doenças do gado leiteiro. São Paulo: Roca, 2000. p. 96-98.

REID, S.W.; MADILL, D.G.; VREUGDENHTL, A.H. Ureaplasma vulvovaginitis and infertility in eigth southern Ontario dairy herds. Can. Vet. J., v. 30, p. 255, 1989.

ROBERTSON, J.; SMOOK, E. Cytochemical evidence of extramembranous carbohydrates on Ureaplasma urealyticum (T-strain Mycoplasma). J. Bacteriol., v. 128, p. 658-660, 1976.

ROBERTSON, J. A.; STEMLER, M. E.; STEMKE, G. W. Immunoglobulin A protease activity of Ureaplasma urealyticum. J. Clin. Microbiol., v. 19, n. 2, p.255-258, 1984.

ROCHA, E. P.; BLANCHARD, A. Genomic repeats, genome plasticity and the dynamics of mycoplasma evolution. Nucleic Acids Res., v. 30, n. 9, p. 20312042, 2002. 
RODWELL, A.W.; MITCHELL. Nutrition, growth and reproduction. In: BARILE, M.F.; RAZIN, S. (Ed.). The mycoplasmas. New York: Acdemic Press, 1979. v. 1, p. 103-109.

RODWELL, A. W.; PETERSON, J. E.; RODWELL, E. S. Macromolecular synthesis and growth of mycoplasmas. Excerpta Med., p. 123-139, 1972.

ROSENDAL, S. Ovine and caprine mycoplasmas. In: WHITFORD, H. W., ROSENBUSCH, R. F., LAUERMAN, L. H. (Ed.). Mycoplasmosis in Animals: Laboratory Diagnosis. lowa: lowa State University Press, 1994. p. 85-93.

ROTTEM, S.; NAOT, Y. Subversion and exploitation of host cells by mycoplasmas. Trends Microbiol., v. 6, n. 11, p. 436-440, 1998.

ROTTEM, S. Invasion of mycoplasmas into and fusion with host cells. In: RAZIN, S. AND HERRMANN, R. (Ed.). Molecular Biology and Pathogenicity of Mycoplasmas. New York: Kluwer Academic, 2002. p. 391-401.

ROTTEM, S. Interaction of mycoplasmas with host cells. Physiol. Rev., v. 83, p. 417-432, 2003.

RUHNKE, H. L.; ROSENDAL, S. Useful protocols for diagnosis of animal mycoplasmas. In: WHITFORD, H. W., ROSENBUSCH, R. F., LAUERMAN, L. H. (Ed.). Mycoplasmosis in Animals: Laboratory Diagnosis. lowa: lowa State University Press, 1994. p. 141-144.

RUHNKE, H. L. Mycoplasmas associated with bovine genital tract infections. In: WHITFORD, H. W.; ROSENBUSCH, R. F.; LAUERMAN, L. H. (Ed.) Mycoplasmosis in Animals: Laboratory Diagnosis. lowa: lowa State University Press, Ames, 1994. p. 56-62.

RUHNKE, H.L., DOIG, P.A., MACKAY, A.L. et. al. Isolation of Ureaplasma from bovine granular vulvitis. Can. Vet. J., v.42, p.151-155, 1978.

RUHNKE, H. L.; PALMER, N. C.; DOIG, P. A.; MILLER, R. B.Bovine abortion and neonatal death associated with Ureaplasma diversum. Theriogenology, $v$. 21, n. 2, p. 295-301, 1984.

SAHU, S. P.; YEDLOUTSCHNIG, R. J. Contagious bovine peluropneumonia. In: WHITFORD, H. W., ROSENBUSCH, R. F., LAUERMAN, L. H. (Ed.). 
Mycoplasmosis in Animals: Laboratory Diagnosis. lowa: lowa State University Press, 1994. p. 39-50.

SANDERSON, M.W.; CHENOWETH, P.J. The role of Ureaplasma diversum in bovine reproduction. Compend. Contin. Educ. Pract. Vet., v. 21, p. S98-S111, 2000.

SAUNDERS, J. E; LUVIRA, F. M. Isolation of ureaplasmas and mycoplasmas from the genital tracts of beef and dairy cattle in Saskatchewan. In: ANNUAL MEETING OF CRWAD, 67., 1986. Abstract... Chicago: Conference of Research Workers in Animal Diseases, 1986. Res. 6.

SCHMIEL, D. H.; MILLER, V. L. Bacterial phospholipases and pathogenesis. Microbes Infect., v. 1, n.13, p.1103-1112, 1999.

SHAW, J. H.; FALKOW, S. Model for invasion of human tissue culture cells by Neisseria gonorrhoeae. Infect. Immun., v. 56, p. 1625-1632, 1988.

SHEPARD, M.C.; LUNCEFORD, C.D.; FORD, D.K.; PURCELL, R.H.; TAYLORROBINSON, D.; RAZIN, S.; BLACK, F.T. Ureaplasma urealyticum gen. nov. sp. nov.: proposed nomenclature for the human $\mathrm{T}$ (T-strain) mycoplasmas. Int. J. Syst. Bacteriol., v. 24, p. 160-171, 1974.

SHIBATA, K.; SASAKI, T.; WATANABE, T. AIDS-associated mycoplasmas possess phospholipases $C$ in the membrane. Infect. Immun., v. 63, n.10, p. 4174-4177, 1995.

SILVA, N. S.; QUINN, P. A. Endogenous activity of phospholipases A and C in Ureaplasma urealyticum. J. Clin. Microbiol., v. 23, n. 2, p. 354-359, 1986.

SILVA, N. S.; QUINN, P. A. Rapid screening assay for phospholipase C activity in mycoplasmas. J. Clin. Microbiol., v. 25, n. 4, p. 729-31, 1987.

SIMECKA, J. W.; DAVIS, J. K.; DAVIDSON, M. K.; ROSS, S. E; STÄDTLANDER, C. T. K-H.; CASSEL, G. H. Mycoplasma Diseases of Animals. In: MANILOFF, J.; MCELHANEY, R. N.; FINCH, L. R.; BASEMAN, J. B. Mycoplasmas Molecular Biology and Pathogenesis. Washington: American Society For Microbiology, 1992. p. 3-22.

SMITS, B.; ROSENDAL, S.; RUHNKE, H. L.; PLANTE, C.; O'BRIEN, P. J.; MILLER, R. B. Effects of Ureaplasma diversum on bovine ovictal explants: 
quantitative measurement using a calmodulin assay. Can. J. Vet. Res., v. 58, p. 114-121, 1994.

SPOONER, R. K.; RUSSELL, W. C.; THIRKELL, D. Characterization of the immunoglobulin A protease of Ureaplasma urealyticum. Infect. Immun., v. 60, n.6, p. 2544-2546, 1992.

STALHEIM, O. H.; PROCTOR, S. J.; GALLAGHER, J. E. Growth abd effects of ureaplasmas (T-mycoplasmas) in bovine oviductal organ cultures. Infect. Immun., v. 13, p. 915-925, 1976.

STÄRK, K. D.; MISEREZ, R.; SIEGMANN, S.; OCHS, H.; INFANGER, P.; SCHMIDT, J. A successful national control programme for enzootic respiratory diseases in pigs in Switzerland. Rev. Sci. Tech., v. 26, n. 3, p. 595-606, 2007.

STIPKOVITS, L.; RÁDY, M.; GLÁVITS, R. Mycoplasmal arthritis and meningitis in calves. Acta Vet. Hung., v. 41, n. 1-2, p. 73-88, 1993.

SUZUKI, Y.; YAMADA, T. Study on rRNA genes in Mycobacterium smegmatis. Microbiol. Immunol., v. 32, n. 12, p. 1259-1262, 1988.

TAJIMA, M.; YAGIHASHI. T. Interaction of Mycoplasma hyopneumoniae with the porcine respiratory epithelium as observed by electron microscopy. Infect. Immun., v. 37, n. 3, p.1162-1169, 1982.

TAJIMA, M.; YAGIHASHI, T.; MIKI, Y. Capsular material of Mycoplasma gallisepticum and its possible relevance to the pathogenic process. Infect. Immun., v. 36, p. 830-833, 1982.

TAMURA, K.; DUDLEY, J.; NEI, M.; KUMAR, S. MEGA4: Molecular Evolutionary Genetics Analysis (MEGA) software version 4.0. Mol. Biol. Evol., v. 24, n. 8, p. 1596-1599, 2007.

TAYLOR-ROBINSON, D.; HAIG, D. A.; WILLIAMS, M. H. Bovine T-strain mycoplasma. Ann. N. Y. Acad. Sci., v. 143, n. 1, 517-518, 1967.

TER LAAK, E. A.; NOORDERGRAAF, J. H.; DIELJES, R. P. Prevalence of Mycoplasmas in the respiratory tracts of pneumonic calves. J. Vet. Med. B., v. 39, n. 8, p. 553-562, 1992. 
TER LAAK, E. A.; VAN DIJK, J. E.; NOORDERGRAAF, J. H. Comparison of pathological signs of disease in specific-pathogen-free calves after inoculation of the respiratory tract with Ureaplasma diversum or Mycoplasma canis. J. Comp. Pathol., v. 108, n. 2, p. 121-132, 1993.

THOMAS, A.; BALL, H.; DIZIER, I.; TROLIN, A.; BELL, C.; MAINIL, J.; LINDEN, A. Isolation of Mycoplasma species from the lower respiratory tract of healthy cattle and cattle with respiratory disease in Belgium. Vet. Rec., v. 151, n. 16, p. 472-476, 2002.

THOMPSON, J. D.; GIBSON, T. J.; PLEWNIAK, F.; JEANMOUGIN, F.; HIGGINS, D. G. The CLUSTAL_X windows interface: flexible strategies for multiple sequence alignment aided by quality analysis tools. Nucleic Acids Res., v. 25, n. 24, p. 4876-4882, 1997.

TIMENETSKY, J.; METTIFOGO, E. Micoplasmas: características gerais e patogenicidade, 2002. Disponível em: <www.icb.usp.br/ bmm/mico>. Acesso em 05 fev. 2003.

TRUSCOTT, R. B. Ureaplasma serotypes associated with the bovine urogenital tract. Can. J. Comp. Med., v. 47, n. 4, p. 471-473, 1983.

TULLY, J.G. Current status of the mollicute flora human. Clin. Infect. Dis., v. 17, p. S2-S9, 1993.

TUÑON, P.; JOHANSON, K. E. Yet improved silver staining method for the detection of proteins in PAGE. J. Biochem. Biophis. Methods., v. 9, p. 171$179,1984$.

UENO, P. M.; TIMENETSKY, J.; CENTONZE, V. E.; WEWER, J. J.; CAGLE, M.; STEIN, M. A.; KRISHNAN, M.; BASEMAN, J. B. Interaction of Mycoplasma genitalium with host cells: evidence for nuclear localization. Microbiology, v. 154, n. 10, p. 3033-3041, 2008.

VAN KUPPEVELD, F. J. M.; VAN DER LOGT, J. T. M.; ANGULO, A. F.; VAN ZOEST, M. J.; QUINT, W. G. V.; NIESTERS, J. M.; GALAMA, J. M. D.; MELCHERS, W. J. G. Genus and Species-Specific Identification of Mycoplasmas by $16 \mathrm{~S}$ rRNA Amplification. Appl. Environ. Microbiol., v. 58, p. 2606-2615, 1992. 
VANCINI, R. G.; BENCHIMOL, M. Entry and intracellular location of Mycoplasma hominis in Trichomonas vaginalis. Arch. Microbiol., v. 189, n. 1, p. 7-18, 2008.

VITOVSKI, S.; DUNKIN, K. T.; HOWARD, A. J.; SAYERS, J. R. Nontypeable Haemophilus influenzae in carriage and disease: a difference in IgA1 protease activity levels. JAVMA, v. 287, n. 13, p.1699-1705, 2002.

VOGL, G.; PLAICKNER, A.; SZATHMARY, S.; STIPKOVITS, L.; ROSENGARTEN, R.; SZOSTAK, M. P. Mycoplasma gallisepticum invades chicken erythrocytes during infection. Infect. Immun., v. 76, n. 1, p. 71-77, 2008.

WEISBURG, W. G.; TULLY, J. G.; ROSE, D. L.; PETZEL, J.P.; OYAIZU, H.; YANG, D.; MANDELCO, L.; SECHREST, J.; LAWRENCE, T. G.; VAN ETTEN, J.; MANILOFF, J.; WOESE, C. R. A phylogenetic analysis of the mycoplama: basis for their classification. J. Bacteriol., v. 171, p. 6455-6467, 1989.

WHITCOMB, R.F., TULLY, J.G. Spiroplasmas, acholeplasmas, and mycoplasmas of plants and arthropods. In: WHITCOMB, R.F.; TULLY, J.G. (Ed.). The mycoplasmas. San Diego: Academic Press, 1989. v. 5.

WIESLANDER, A.; BOYER, M. J.; WROBLEWSKI, H. Membrane Protein structure. In: MANILOFF J.; MCELHANEY, R. N.; FINCH L.R.; BASEMAN J. B. (Ed.). Mycoplasmas: molecular biology and pathogenesis. Washington: American Society for Microbiology, 1992. p. 93-112.

WINNER, F.; ROSENGARTEN, R.; CITTI, C. In vitro cell invasion of Mycoplasma gallisepticum. Infect. Immun., v. 68, p.4238-4244, 2000.

WOESE, C. R.; STACKEBRANDT, E.; LUDWIG, W. What are mycoplasmas: the relationship of time and mode in bacterial evolution. J. Mol. Evol., v. 21, p. 305-316, 1985.

YAVLOVICH, A.; HIGAZI, A. A.; ROTTEN, S. Plasminogen binding and activation by Mycoplasma fermentans. Infect. Immun., v. 69, p. 1977-1982, 2001.

YAVLOVICH, A.; TARSHIS, M.; ROTTEM, S. Internalization and intracellular survival of Mycoplasma pneumoniae by non-phagocytic cells. FEMS Microbiol. Lett., v. 233, p. 241-246, 2004. 
YOU, X. X.; ZENG, Y. H.; WU, Y. M. Interactions between mycoplasma lipidassociated membrane proteins and the host cells. J. Zhejiang Univ. Sci. B., v. 7, n. 5, p. 342-350, 2006. 